\title{
SOSECAN
}

TOUS UNIS CONTRE LES CANCERS
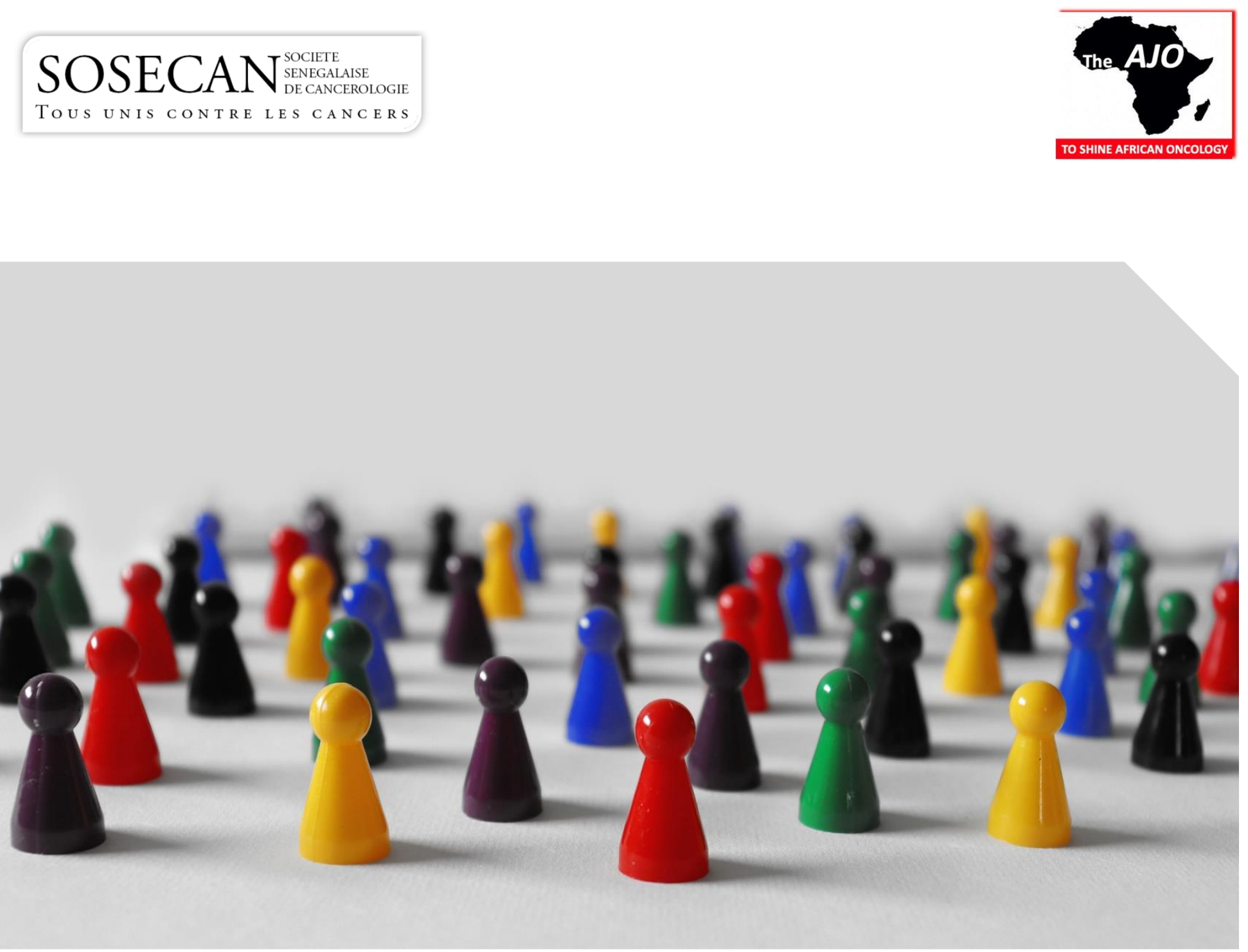

\section{AFRICAN JOURNAL OF DICOLOCY}

\section{JOURNAL AFRI
D'ONCOLIOCIE}

ISSN 2772-2457

Volume I - Issue 2 - July 202 I

Volume I - Issu 2 - Juillet 2021 
This page is intentionally left blank.

Cette page est laissée blanche intentionnellement. 
An official journal of the / Un journal officiel de la "Société Sénégalaise de Cancérologie" (SOSECAN)

Journal homepage: www.africanjournalofoncology.com

\section{Editor-in-Chief / Rédacteur en chef}

Ahmadou Dem, Surgical oncology, Senegal

\section{Editorial board / Comité éditorial}

Léra Géraud Cécil Kévin Akpo, radiology, Senegal

Salif Baldé, medical oncology, Senegal

Mamadou Moustapha Dieng, radiotherapy, Senegal
AFRICAN JOURNAL OF ONCOLOCY

IOURNAL AFRICAIN D'ONCOLOCIE

Cancérologie" (SOSECAN) 
An official journal of the / Un journal officiel de la "Société Sénégalaise de Cancérologie" (SOSECAN) Journal homepage: www.africanjournalofoncology.com

Presentation and aims

The African Journal of Oncology is the official journal of the Société Sénégalaise de Cancérologie (SOSECAN). It provides publications in various fields related to oncology. With its large editorial board, it aims to offer innovative publications. This journal is available in electronic format through its website:

\section{www.africanjournalofoncology.com}

African Journal of Oncology (ISSN 2772-2457) comprises 2 issues per volume with possibly supplements. Volume I is scheduled for 2021.

Submissions and Authors

Manuscripts are submitted on the journal's official website (Submission tab). For any further information, you can contact us by email:

\section{africanjournalofoncology@gmail.com}

Copyrights and reprints

This journal is protected for copyright under the law in force in Senegal. Some publications may be subject to additional copyright. The corresponding author is authorized to provide this additional information. Copies and storage in any form are only permitted for personal use. For all other uses, please contact us by email for mutual arrangement:

\section{africanjournalofoncology@gmail.com}

All published texts are available under license Creative Commons: Attribution 4.0 International (CC BY 4.0); other conditions may apply.

Notice

Due to the rapid development of diagnostic methods, treatments and understanding of diseases, SOSECAN and the journal's editorial board assume no responsibility for the effects caused, damage or any other form related to the content of the journal. Although certain advertising products may be displayed in this journal, SOSECAN and the editorial board assume no responsibility for their possible use, nor do they guarantee their quality or value.

\section{AFRICAN JOURNAL OF ONCOLOCY IOURNAL AFRICAIN O'ONCOLOCIE}

UDURAL AFRICAII

\section{Présentation et Buts}

Le Journal Africain d'Oncologie est le journal officiel de la Société Sénégalaise de Cancérologie (SOSECAN). Il fournit des publications dans divers domaines en rapport avec l'oncologie. Avec son large comité d'édition, il vise à proposer des publications innovantes. Ce journal est proposé dans un format électronique à travers son site internet :

\section{www.africanjournalofoncology.com}

Journal Africain d'Oncologie (ISSN 2772-2457) comporte 2 issus par volume avec éventuellement des numéros supplémentaires. Le volume I est programmé pour 2021.

Soumissions et Auteurs

La soumission des manuscrits se fait sur le site officiel du journal (onglet Soumission). Pour toutes informations complémentaires, vous pouvez nous contacter par email :

\section{africanjournalofoncology@gmail.com}

Droits d'auteurs et réutilisation

Ce journal est protégé pour les droits d'auteur selon la loi en vigueur au Sénégal. Certaines publications peuvent être soumises à d'additionnels droits d'auteur. L'auteur correspondant est habilité à fournir ces renseignements complémentaires. Les copies et le stockage sur n'importe quel support ne sont permis que pour un usage personnel. Pour tout autre usage, veuillez nous contacter par email pour arrangement mutuel :

\section{africanjournalofoncology@gmail.com}

Tous les textes publiés sont disponibles sous licence Creative Commons: Attribution 4.0 International (CC BY 4.0); d'autres conditions peuvent s'appliquer.

Note

A cause de l'évolution rapide des méthodes diagnostiques, des traitements et de la compréhension des maladies, la SOSECAN et le comité éditorial du journal n'assume aucune responsabilité sur les effets causés, les dommages ou tout autre forme en rapport avec le contenu du journal. Bien que certains produits publicitaires puissent être affichés dans ce journal, la SOSECAN et le comité d'éditeur n'assume aucune responsabilité sur leur éventuel usage, ni ne garantit leur qualité ou leur valeur.

Cover image / Image de couverture

Image offered by geralt on the Pixabay platform at the following address: / Image proposée par geralt sur la plateforme Pixabay à l'adresse suivante : https://pixabay.com/fr/illustrations/communaut\%c3\%a9-concept-unit\%c3\%a9-compagnie-6706845/ 
An official journal of the / Un journal officiel de la "Société Sénégalaise de Cancérologie" (SOSECAN)

Journal homepage: www.africanjournalofoncology.com

Editorial / Editoriale

Become stronger through diversity

Devenir plus fort à travers la diversité

S. Ka, MM. Dieng, ME. Charfi, A. Dem

Recommendations / Recommandations

Vaccination against Covid-19: Recommendations of the Senegalese Cancer Society (SOSECAN)

Vaccination contre la Covid-19: Recommandations de la Société Sénégalaise de Cancérologie (SOSECAN)

ME. Charfi, DM. Niang, RD. Niang, M. Mané, S. Baldé, AO. Touré, M. Guèye, SMK. Guèye, B. Ba, K. Ka, J. Thiam, S. Dieng, AC. Diallo, LG.

Akpo, D. Diouf, MM. Dieng, S. Ka, PM. Gaye, A. Dem

Review / Synthèse

Factors associated with oral cavity cancers in Sub-Saharan Africa: Summary of the literature

Facteurs associés aux cancers de la cavité orale en Afrique Subsaharienne : Synthèse de la littérature

A. Dieng, AD. Faye, MM. Ndiaye, G. Diop, A. Bouazé, M. Diouf.

Breast reconstruction after breast cancer

Reconstruction mammaire pour cancer du sein

ME. Charfi, S. Ka, A. Dem.

Originals articles / Articles originaux

Giant uterine leiomyoma delivered through the cervix: About three cases in Ouagadougou

Léiomyome utérin géant accouché par le col : A propos de trois cas à Ouagadougou

N. Zongo, AH. Bagué, M. Windsouri, PB. Yaméogo, NML. Ouédraogo, J. Sawadogo

Dermatofibrosarcoma protuberans at Niamey National Hospital: About I 2 cases

Le dermatofibrosarcome de Darier et Ferrand à l'Hôpital National de Niamey: A propos de 12 cas

A. Soumaila, Al. Dourahamane, I. Dillé, OS. Galadima, HM. Zaki, G. Hakimi, YD. Harouna.

Management of cutaneous melanoma at the Joliot Curie Institute in Dakar

Prise en charge des mélanomes cutanés à I'Institut Joliot Curie de Dakar

JC. Balegana, S. Ka, D. Diouf, J. Thiam, M. Dieng, PM. Gaye, M. Diop, A. Dem

Profile of parotid cancers at the ENT clinic Lamine Sine Diop of Fann teaching hospital

Profil des cancers de la parotide à la clinique ORL Lamine Sine Diop du CHU de Fann

A. Dièye, H. Younés, C. Ndiaye, H. Ahmed, L. Yassine, B. Loum, M. Ndiaye, IC. Ndiaye

Case report / Cas clinique

Undifferentiated carcinoma of the nasopharynx associated with an early paraneoplastic dermatomyositis TINOM0: About a one case Carcinome indifférencié du nasopharynx associé à une dermatomyosite paranéoplasique à un stade précoce TIN0M0 : A propos

d'un cas et revue de la littérature

S. Panandtigri, M. Charkaoui, NPX. Sia, N. Benchakroun, C. Tarek, M. Bourhafour, Z. Bouchbika, H. Jouhadi, N. Tawfiq, S. Saharaoui, A.

Benider

Giant jejunal gasto-intestinal stromal tumor: A rare cause of abdominal mass in an elderly female

Tumeur stromale gastro-intestinale à localisation jéjunale : Une rare cause de masse abdominale chez la femme âgée

AC. Diallo, A. Ndong, I. Niang, MB. Ba, JA. Thiam, PS. Dieng, S. Ka, I. Konate, A. Dem 
This page is intentionally left blank.

Cette page est laissée blanche intentionnellement. 
An official journal of the / Un journal officiel de la "Société Sénégalaise de Cancérologie" (SOSECAN)

Journal homepage: www.africanjournalofoncology.com

Editorial / Editoriale

DOI: https://www.doi.org/I0.54266/ajo.I.2.3I.EPJF6430

\section{Become stronger through diversity}

\section{Devenir plus fort à travers la diversité}

S. Ka ${ }^{\prime *}$, MM. Dieng', ME. Charfi', A. Dem'.

' Institut Joliot Curie de Dakar, Sénégal.

La cancérologie est une discipline multidisciplinaire. Ne dit-on pas : " malheur à celui qui se veut cancérologue tout seul?". Autant la chirurgie est traditionnellement considérée comme la pierre angulaire du traitement des cancers solides, autant les traitements médicaux des cancers et la radiothérapie, au-delà de leurs caractères néo-adjuvants ou adjuvants, indispensables pour assurer une meilleure prise en charge des cancers, tendent de plus en plus à repousser les frontières des intervalles de survie [I, 2].

Certains cancers solides sont connus depuis des décennies comme curables par la seule chimiothérapie. Les exemples en sont les tumeurs embryonnaires et les tumeurs de l'enfant dont les formes métastatiques peuvent être guéries jusqu'à l'ordre de $80 \%$ [3]. D'autres sont traités exclusivement par la radiothérapie ou par le couple potentialisateur que constitue la radio-chimiothérapie. Comme c'est le cas des cancers du col de l'utérus ou ORL [4].

En Afrique, dans un contexte de ressources modestes, on retrouve 2 situations morbides particulières que sont la rareté de la ressource humaine qualifiée dans le traitement des cancers et les limites de l'organisation des systèmes [5].

Peu de pôles académiques proposent la formation de spécialistes dans les différents domaines de la cancérologie et peu de centres favorisent la synergie des actions des différents praticiens. Comme en atteste la rareté des réunions de concertations pluridisciplinaires (RCP) dont l'impact positif est établi [6].

Les outils de vulgarisation de la cancérologie notamment les journaux spécialisés doivent s'ouvrir à ces différents aspects et participer à la promotion des bonnes pratiques en cancérologie.

Cette étape de la vie du Journal Africain d'Oncologie coïncide avec la plus vaste campagne de vaccination jamais entreprise par l'humanité. Des interférences manifestes existent entre les soins en cancérologie et la prise en charge des patients dans ce contexte de pandémie à la Covid-19. D'où la nécessaire publication des recommandations pour la vaccination chez les patients en cancérologie.

Le Journal Africain d'Oncologie à travers la diversité de son comité éditorial participera en âme et conscience, avec la vérité scientifique ou ce qui s'en rapproche le plus à l'état actuel des connaissances et des moyens disponibles en bandoulière, à relever les niveaux de connaissances en cancérologie et à mettre au même niveau d'informations les formateurs, les praticiens, les décideurs et les populations.

\section{CONFLITS D'INTERET}

Les auteurs n'ont déclaré aucun conflit d'intérêts.

\section{REFERENCES}

I. Kemeny M. Surgical oncology. Am J Surg. 2007; 193(I): 133-4.

2. Popescu RA, Schäfer R, Califano R, Eckert R, Coleman $R$, Douillard JY et al. The current and future role of the medical oncologist in the professional care for cancer patients: a position paper by the European Society for Medical Oncology (ESMO). Ann Oncol. $2014 ; 25(1): 9-15$.

3. Adra N, Einhorn LH. Testicular cancer update. Clin Adv Hematol Oncol. 20I7; I5(5):386-396.

4. Naga Ch P, Gurram L, Chopra S, Mahantshetty U. The management of locally advanced cervical cancer. Curr Opin Oncol. 2018;30(5):323-329.

5. Mutebi M, Adewole I, Orem J, Abdella K, Coker O, Kolawole I et al. African Cancer Coalition. Toward Optimization of Cancer Care in Sub-Saharan Africa: Development of National Comprehensive Cancer Network Harmonized Guidelines for Sub-Saharan Africa. JCO Glob Oncol. 2020 Sep;6:14I2-1418.

6. Brandão M, Guisseve A, Bata G, Firmino-Machado J, Alberto M, Ferro J et al. Survival Impact and CostEffectiveness of a Multidisciplinary Tumor Board for Breast Cancer in Mozambique, Sub-Saharan Africa. Oncologist. 2021;26(6):e996-el 008. 
An official journal of the / Un journal officiel de la "Société Sénégalaise de Cancérologie" (SOSECAN)

Journal homepage: www.africanjournalofoncology.com

Recommendations / Recommandations

DOI: https://www.doi.org/I0.54266/ajo.I.2.32.NZCY2635

\section{Vaccination against Covid- I9: Recommendations of the Senegalese Cancer Society (SOSECAN) \\ Vaccination contre la Covid-19: Recommandations de la Société Sénégalaise de Cancérologie (SOSECAN)}

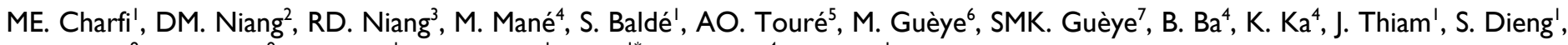
AC. Diallo', LG. Akpo', D. Diouf', MM. Dieng', S. Ka', PM. Gaye', A. Dem'.

I Institut Joliot Curie de Dakar, Sénégal.

${ }^{2}$ Service d'Immunologie, Hôpital Aristide le Dantec, Dakar, Sénégal.

${ }^{3}$ Service de Chirurgie Générale, Hôpital Idrissa Poye, Yoff, Sénégal.

${ }^{4}$ Service de Radiothérapie, Hôpital Dalal Jamm, Sénégal.

${ }^{5}$ Service de Chirurgie générale, Hôpital Aristide le Dantec, Dakar, Sénégal.

${ }^{6}$ Service de Gynécologie et Obstétrique, Hôpital Aristide le Dantec, Dakar, Sénégal.

${ }^{7}$ Université de Ziguinchor, Sénégal.

${ }^{8}$ UFR 2S, Université Gaston Berger de Saint-Louis, Sénégal.

9 Service d'Imagerie Médicale, Hôpital Aristide le Dantec, Dakar, Sénégal.

\section{INTRODUCTION}

Le cancer est une maladie complexe qui atteint tous les organes du corps humain. II a la particularité de se disséminer à tout l'organisme. II existe des cancers dits solides qui atteignent les organes pleins comme le sein, la prostate, le foie et des cancers appelés hémopathies malignes qui intéressent le sang, la moelle osseuse et les cellules du système immunitaire [I].

Le patient atteint de cancer est appelé à recevoir des traitements curatifs en vue d'une guérison complète ou palliatifs accompagnant toutes les étapes du traitement chez le malade qui peut guérir ou non. Les soins palliatifs concernent les cancers avancés et les patients en fin de vie. Les traitements du cancer sont nombreux et les plus fréquents sont la chirurgie, la radiothérapie et les traitements médicaux tels que la chimiothérapie et les thérapies ciblées. Ces traitements interagissent avec la maladie mais aussi avec l'organisme du patient et peuvent modifier son état physiologique, immunitaire et nutritionnel [2].

Parallèlement à leur maladie cancéreuse, les patients peuvent également souffrir de maladies intercurrentes que celles-ci soient chroniques ou infectieuses aigues.

Les patients suivis pour maladie chronique ou qui sont sous des traitements particuliers ayant un effet sur le système immunitaire (chimiothérapie, radiothérapie, autres traitements du cancer) ont 2 à 5 fois plus de risque d'admission en soins intensifs pour forme grave ou de décès. Pour ces raisons, leur protection par la vaccination est essentielle avant, pendant et après la maladie cancéreuse.

\section{RELATIONS COVID-I 9 ET CANCER}

La Covid-19 est une maladie virale respiratoire à expression systémique, contagieuse et potentiellement létale pour tous les patients mais avec un plus grand risque de décès chez les personnes présentant des affections qui les fragilisent comme les cancers. Elle entraine des complications dont les plus fréquentes sont une altération étendue de la fonction pulmonaire et une maladie thromboembolique. Le cancer et ses traitements entrainent également une altération immunitaire, une atteinte pulmonaire fréquente et une plus grande susceptibilité à la maladie thromboembolique. Les patients présentant un cancer avancé et qui développent une Covid-19 sont susceptibles d'être diagnostiqués tardivement d'une infection par le SARS-Cov 2 et de s'aggraver rapidement, ce qui entraine une plus grande probabilité de décès; principalement pour les cancers du poumon, les cancers avancés et les hémopathies malignes. La survenue d'une infection au SARS-Cov 2 en cours de traitement anti cancéreux retarde la mise en œuvre ou la régularité de ce traitement [3].

\section{ETAT DE LA RECHERCHE DE LA VACCINATION CONTRE LA COVID-I 9}

Des efforts de recherche et de collaboration inédits ont permis de mettre au point et de valider des vaccins efficaces antiCovid-19, mettant ainsi à disposition un moyen de prévention de la gravité et des décès liés à cette maladie en particulier chez les patients fragiles tels que ceux atteints de cancers.

Les vaccins régulièrement disponibles au Sénégal sont: un

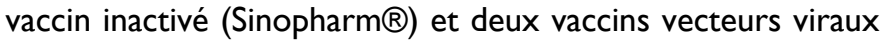
(Oxford-Astrazeneca $®$, Janssen $®)$. A l'instar des vaccins à ARN (Pfizer-BioNTech®, Moderna $®$ ), ils ont pour objectif principal une induction d'une réponse et d'une mémoire immunitaire ciblant la protéine $S$ indispensable au développement de la maladie liée au virus de la Covid- 19.

Le mode d'administration est une injection qui n'interfère pas avec la mise en œuvre des traitements anticancéreux.

Le patient atteint de cancer peut se trouver à plusieurs états physiologiques et pathologiques selon le type de cancer, son stade d'évolution et le terrain associé (Diabète, $\mathrm{VIH}$, cardiopathies, etc.).

Les traitements anticancéreux peuvent altérer le système immunitaire mais n'interfèrent pas avec le processus d'efficacité de la vaccination sauf dans de rares cancers impliquant dans leurs mécanismes des effecteurs du système 
immunitaire notamment les cellules B (anti-CDI9, anti-CD20, CAR-T cells) [4].

\section{METHODOLOGIE DE TRAVAIL POUR L'ELABORATION DES RECOMMANDATIONS}

Un formulaire inspiré des recommandations de sociétés savantes américaines et européennes a été diffusé à tous les membres de la Société Sénégalaise de Cancérologie [5]. II portait sur les connaissances globales en cancérologie, sur les connaissances sur la Covid-19, sur l'état d'avancement de la recherche sur les vaccins contre la Covid-19, sur les recommandations des autres sociétés savantes en cancérologie et sur les interrelations possibles entre la vaccination et les cancers évolutifs ou en rémission.

La synthèse a été effectuée par un comité restreint de 4 membres et la proposition de validation a été partagée à tous les membres. Il en est sorti les recommandations suivantes.

\section{RESULTATS}

I. Les patients atteints d'un cancer évolutif ou en rémission ou déclarés guéris doivent être vaccinés en priorité sans choix préférentiel du type de vaccin s'il est autorisé au Sénégal.

2. Tous les patients recevant un traitement anti cancéreux en cours sont encouragés à la vaccination.

3. La vaccination contre la Covid-19 doit être reportée si le patient atteint de cancer a été malade récemment de la Covid-19 ou si le patient a eu une greffe de cellules hématopoḯtiques ou une thérapie cellulaire modifiée. Dans ce cas, un recul de 3 à 6 mois est recommandé et est laissé à l'appréciation du médecin cancérologue.

4. Les patients sous chimiothérapie doivent bénéficier d'un monitorage obligatoire de la formule sanguine qui permettra d'évaluer et de corriger les constantes et donc permettre la vaccination en cas de normalisation du compte des globules blancs. II est recommandé d'administrer la vaccination dans l'intercure plutôt qu'au début ou en cours d'administration (cure) de la chimiothérapie.

5. Lorsqu'une chirurgie est programmée, la vaccination devrait être décalée de quelques jours.

6. Lorsqu'un curage ganglionnaire de l'aisselle a été effectué (cancer du sein ou cancer du membre supérieur), l'injection se fera au bras opposé au curage ganglionnaire.

7. La radiothérapie ne devrait pas retarder l'administration du vaccin.

8. Les patients présentant des affections non curables et sous traitement palliatif peuvent bénéficier de la vaccination contre la Covid-19 sauf si une indication contraire, jugée sur le pronostic à court terme, l'altération de l'état général et des fonctions physiologiques, provient de leur médecin traitant.

9. II n'y a pas de préférence de vaccin en ce qui concerne les patients atteints de cancer au Sénégal. Mais si un vaccin à injection unique est disponible, ce dernier doit être préféré pour les patients ayant eu un curage axillaire ou ayant une lésion maligne évolutive ou non sur le membre supérieur.

\section{CONFLITS D'INTERET}

Les auteurs n'ont déclaré aucun conflit d'intérêts.

\section{REFERENCES}

I. Hausman DM. What Is Cancer? Perspect Biol Med. 2019; 62(4): 778-784.

2. Plenderleith $\mathrm{IH}$. Treating the treatment: toxicity of cancer chemotherapy. Can Fam Physician. 1990; 36: 1827-30.

3. Zong Z, Wei Y, Ren J, Zhang L, Zhou F. The intersection of COVID-19 and cancer: signaling pathways and treatment implications. Mol Cancer. 202I; 20(I): 76.

4. Ghasemiyeh P, Mohammadi-Samani S, Firouzabadi N, Dehshahri A, Vazin A. A focused review on technologies, mechanisms, safety, and efficacy of available COVID-19 vaccines. Int Immunopharmacol. 202I; 100: 108162.

5. Kharmoum S, El M'Rabet FZ. La vaccination antiCOVID- 19 et patients atteints de cancer : état de l'art et synthèse des recommandations [COVID-19 vaccines and cancer patients: State of the art and guidelines summary]. Bull Cancer. 2021 ; 108(5): 553 555. 
An official journal of the / Un journal officiel de la "Société Sénégalaise de Cancérologie" (SOSECAN)

Journal homepage: www.africanjournalofoncology.com

Review / Synthèse

DOI: https://www.doi.org//0.54266/ajo.I.2.34.MEUN5028

\title{
Factors associated with oral cavity cancers in Sub-Saharan Africa: Summary of the literature
}

\section{Facteurs associés aux cancers de la cavité orale en Afrique Subsaharienne : Synthèse de la littérature}

\author{
A. Dieng'*, AD. Faye², MM. Ndiaye³, G. Diop", A. Bouazé', M. Diouf'. \\ I Service de Santé Publique, Institut Odontostomatologie, Faculté de médecine, de Pharmacie et d’Odontostomatologie, UCAD, Dakar, Sénégal. \\ ${ }^{2}$ Service de Stomatologie et Chirurgie maxillo-faciale, UFRSS, UIDT, Thiès, Sénégal. \\ ${ }^{3}$ Service de Stomatologie et Chirurgie maxillo-faciale, Faculté de médecine, de Pharmacie et d’Odontostomatologie, UCAD, Dakar, Sénégal. \\ ${ }^{4}$ Département de Biologie Animale, FST, UCAD, Dakar, Sénégal.
}

INTRODUCTION: Oral cavity cancers are now a public health problem according to WHO epidemiological data. There are several risk factors or factors associated with cancers of the oral cavity but they vary according to geographic regions. OBJECTIVE: The objective of this study was to identify factors associated with cancers of the oral cavity in Sub-Saharan African populations through a systematic literature review. METHODOLOGY: Using the data available for the period from January I 980 to December 2019, a synthesis of the literature was carried out. The literature localization strategy included an electronic search of the MEDLINE, EMBASE and GOOGLE SCHOLAR databases from 1980 to 2019 and a manual search of the list of references of articles identified by snowballing. The data were extracted independently by two researchers on an Excel(C) spreadsheet. Parameters collected from each study were author, country, type of study, period of study, size, age, gender, and factors studied. RESULTS: Out of I,318 articles found, 24 were selected. The data contained 17,290 patients including 8,229 men, i.e. a male / female sexratio of 0.91 . Factors studied were tobacco, alcohol, diet, infection, genetics and social factors. CONCLUSION: The results reported showed that several factors are associated with the occurrence of oral cavity cancers in Sub-Saharan Africa. There is a need to conduct further studies with more structured methodologies for more convincing results.

KEYWORDS: Oral cavity; Cancer; Sub-Saharan Africa; Associated factors; Sytematic review.

INTRODUCTION : Les cancers de la cavité orale constituent aujourd'hui un problème de santé publique selon les données épidémiologiques de l'OMS. II existe plusieurs facteurs associés aux cancers de la cavité orale mais ils sont variables selon les régions géographiques. OBJECTIF : L'objectif de ce travail était d'identifier les facteurs associés aux cancers de la cavité orale chez les populations d'Afrique Subsaharienne à travers une revue systématique de la littérature. METHODE : A travers les données disponibles de la période de Janvier 1980 à Décembre 2019, une synthèse de la littérature a été réalisée. La stratégie de localisation des écrits comportait une recherche électronique dans les bases de données MEDLINE, EMBASE et GOOGLE SCHOLAR de I980 à 2019 et une recherche manuelle dans la liste des références des articles identifiés par effet boule de neige. Les données ont été extraites de façon indépendante par deux chercheurs sur un tableur ExcelC. Les paramètres recueillis de chaque étude étaient l'auteur, le pays, le type d'étude, la période d'étude, l'effectif, l'âge, le sexe et les facteurs étudiés. RESULTATS : Sur I.3। 8 articles retrouvés, 24 ont été sélectionnés. Les données contenaient 17.290 patients dont 8.229 hommes soit un sex-ratio 0,91 . Les facteurs étudiés étaient le tabac, l'alcool, l'alimentation, l'infection, la génétique et les facteurs sociaux. CONCLUSION : Les résultats rapportés montraient que plusieurs facteurs sont associés à la survenue des cancers de la cavité orale en Afrique Subsaharienne. Leur identification et leur contrôle permettraient de réduire la morbidité et mortalité de cette pathologie.

MOTS-CLES : Cancer ; Cavité orale ; Afrique Subsaharienne ; Facteurs associés ; Revue systématique.

\section{INTRODUCTION}

Le cancer constitue aujourd'hui un problème de santé publique mondiale selon les données épidémiologiques de l'Organisation Mondiale de la Santé (OMS) [I]. La majorité des cas incidents ainsi que le taux de morbi-mortalité due au cancer se retrouvent dans les pays sous-développés et plus particulièrement en Afrique Subsaharienne. Dans cette région du monde, la transition épidémiologique est plus qu'une réalité avec une projection du taux de décès due au cancer de l'ordre de $85 \%$ en 2030 [2]. Les registres de cancer basés sur la population montrent que l'incidence croissante du cancer est probablement due à plusieurs facteurs notamment l'occidentalisation des modes de vie [3, 4]. Dans les pays développés, la détection précoce du cancer est le fruit des avancés sur la biologie et la pathogénèse des tumeurs contrairement en Africaine Subsaharienne [5, 6]. II existe plusieurs facteurs de risque ou associés aux cancers de la cavité orale mais ils sont variables selon les régions géographiques. [7].

L'objectif de ce travail était de faire une revue systématique limitée aux cancers de la cavité orale définie par les codes C00-

* Corresponding author: Dr Amadou Dieng, Maître de Conférences Assimilé en Santé Publique, Service de Santé Publique, Institut Odontostomatologie, Faculté de médecine, de Pharmacie et d'Odontostomatologie, UCAD, Dakar, Sénégal. Tél : +221773769006 - +22I76633II43. Email : adieng00@gmail.com amadou7.dieng@ucad.edu.sn. 
C06 de la CIM-I0 ou les codes I40, I4I, I43-I45 de la CIM-9 chez les populations d'Afrique Subsaharienne.

\section{MATERIELS ET METHODES}

Une synthèse de la littérature a été réalisée conformément aux lignes directrices de la grille PRISMA (Preferred Reporting Items for Systematic Reviews and Meta-Analyses). Dans cette perspective, une question de recherche a été formulée. Une stratégie de recherche ad hoc, destinée à retrouver tous les écrits ou toutes les études pertinentes de 1980 à 2019 sur la question. Les études incluses sur la base de critères édictés à priori étaient analysées et les données qu'elles renfermaient extraites et synthétisées.

Le problème de recherche qui justifie la mise en œuvre de cette revue systématique, posée sous la forme PEO ( $\mathrm{P}=$ Population, $\mathrm{E}=$ Exposition et $\mathrm{O}=$ Résultats), est la suivante : "Quels sont les facteurs de risque ou facteurs associés aux cancers de la cavité orale chez les populations d'Afrique Subsaharienne ? ॥. La population d'étude est constituée de toutes personnes vivantes en Afrique Subsaharienne quel que soit leur âge ou leur sexe et présentant un cancer de la cavité orale. Des études ont été incluses sur tous les facteurs associés au risque des cancers oraux. Soient les facteurs modifiables que sont les facteurs environnementaux, professionnels et liés au mode de vie, facteurs nutritionnels et diététiques, facteurs viraux et les facteurs non modifiables que sont les antécédents personnels et les antécédents familiaux.

Un diagnostic positif des cancers de la cavité orale, les résultats rapportés portaient sur les cancers de la cavité orale (définie comme précédemment) ou un ou plusieurs sites anatomiques de la cavité orale (lèvres, langue, gencives, plancher buccal, palais, joues, vestibules, trigones rétro-molaires). Pour les études portant sur les cancers des voies aéro-digestifs supérieures (VADS) en général, des résultats séparés pour la cavité orale définie comme précédemment étaient présentés. La stratégie de recherche des articles comportait deux étapes : une recherche électronique dans les bases de données d'articles scientifiques et une recherche manuelle dans la liste des références des articles identifiés par effet boule de neige. Les données ont été extraites de façon indépendante par deux praticiens (sur un tableur Excel@). Les paramètres recueillis de chaque étude étaient l'auteur, le pays, le type d'étude, la période d'étude, l'effectif, l'âge, le sexe et les facteurs étudiés. La stratégie de recherche, appliquée aux différentes bases de données ciblées a permis de retrouver 1.318 articles qui se répartissent comme suit (Figure I) :

- MEDLINE par l'interface Pubmed: 191 écrits, tous des articles scientifiques.

- EMBASE par l'interface Science Direct : 919 articles de journaux scientifiques.

- GOOGLE SCHOLAR a fourni 62 articles.

- La recherche manuelle a fourni I46 articles.

\section{RESULTATS}

Les informations contenues dans les 24 articles restants ont été extraites et synthétisées dans le tableau I (Annexes). La plupart de ces articles étaient en langue anglaise, trois étaient en français et tous ont été publiés entre 1980 et 2019.

\section{Caractéristiques des études}

Les résultats obtenus font état de $\mathbf{1 7 . 2 9 0}$ patients dont 9.061 femmes donnant un sex-ratio de 0,91 . Les pays concernés étaient: Afrique du Sud, Burkina Faso, Kenya, Mauritanie, Malawi, Mali, Nigéria, Sénégal et Soudan.

La période effective de sélection de ces articles est de 1987 à 2017. L'ensemble des informations est résumé dans le tableau I (Annexes).

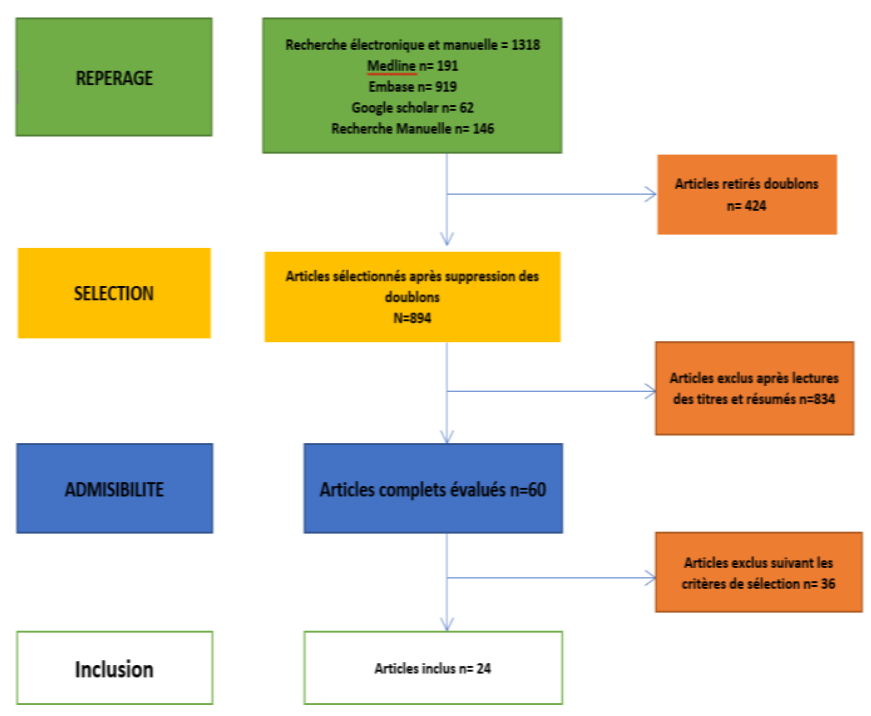

Figure I : Diagramme de flux QUOROM pour la sélection des articles.

Facteurs étudiés

Quatre études menées au Soudan, au Burkina Faso et deux en Afrique du Sud ont fait état de relation entre le tabac et les cancers de la cavité orale.

Alcool : Parmi les études incluses, $16,67 \%$ ont indiqué la relation entre l'alcool et les cancers de la cavité orale.

Tabac et alcool : Près de $1 / 6^{\text {ème }}$ des études ont abordé la relation du couple tabac-alcool et les cancers de la cavité orale. Tabac, alcool et état nutritionnel : Une étude de cas menée en Afrique du Sud a révélé que le tabac, l'alcool, l'état nutritionnel sont des facteurs associés au développement des cancers de la cavité orale.

Tabac, noix de cola et profession agriculteur: Deux études incluses au Kenya et au Nigéria indiquent qu'il existe une association entre consommation du tabac, de noix de cola, la profession d'agriculteur et cancers de la cavité orale.

Tabac, alcool et hygiène orale : Un travail mené en 2007 au Mali a abordé la relation entre le tabac, l'alcool, l'hygiène orale et le cancer de la cavité orale.

Tabac, produits chimiques, habitudes orales, environnement et caractéristiques génétiques (facteurs héréditaires): Une étude réalisée au Soudan a mise en exergue le lien entre les produits chimiques, le tabac, les habitudes orales, l'environnement, les caractéristiques génétiques (facteur héréditaire) et les cancers de la cavité orale.

Caractéristiques génétiques, hygiène orale et état nutritionnel : Deux travaux réalisés en Mauritanie et au Nigéria ont mis en évidence l'association entre les caractéristiques génétiques, l'hygiène orale ainsi que l'état nutritionnel et les cancers de la cavité orale.

Infection et facteurs comportementaux : Deux études dont l'une portant sur le rôle de l'infection virale dans la transformation maligne et les facteurs comportementaux, montrent un lien entre ces derniers et les cancers de la cavité 
orale en raison de la présence élevée de HPV dans les lésions buccales due au lichen plan buccal (LPB).

Virus de l'herpès humain (HHV-8) : Une étude menée au Sénégal a signifié l'association de l'herpès virus humain 8 (HHV8) aux cancers de la cavité orale.

\section{DISCUSSION}

\section{Limites de l'étude}

Les meilleurs articles scientifiques, concernant les facteurs associés aux cancers de la cavité orale en Afrique Subsaharienne ont été regroupés et synthétisés dans cette revue $[8,9]$. Cette démarche offre plusieurs avantages aux chercheurs, car elle permet une identification et une mise à jour des principales connaissances scientifiques liées à cette pathologie.

Sur un total initial de 1.318 écrits retrouvés pour une inclusion dans l'étude, au final, seuls 24 articles scientifiques ont été retenus. La dernière inclusion d'études dans la présente revue date du 12/12/2019. Les revues sur les facteurs associés aux cancers de la cavité orale sont rares voire inexistantes. En fait, aucune étude concernant ce sujet n'a été retrouvée dans la littérature. Cette revue présente certaines limites liées essentiellement à la qualité des études, au choix du type d'étude et à l'évaluation de leur qualité. La qualité des études retenues a été évaluée de façon objective en utilisant une démarche rigoureuse d'outil de lecture critique d'article. Ce procédé a été fait sur la base de dernières recommandations concernant les études observationnelles. Les études présentant un risque de biais élevés ont été supprimées. La stratégie de recherche dans les différentes bases de données et les autres sources de la littérature scientifique ont permis de faire la synthèse de 24 articles.

\section{Facteurs de risque traditionnels}

Essentiellement liés de la diversité ethnique, l'environnement et les disparités socio-économiques, la difficulté d'accès aux établissements de santé, les informations sur l'étiologie du cancer en Afrique Subsaharienne, tout comme l'épidémiologie, qui sont erratiques.

\section{Tabac}

L'usage du tabac est répandu dans les pays africains subsahariens. Plus de $90 \%$ des cas de cancers oraux déclarent utiliser des produits du tabac. Le tabac étant un facteur de risque indépendant, le risque relatif aux cancers oraux chez les fumeurs est II fois plus élevé que chez les personnes qui n'ont jamais consommé de tabac [10]. Il est utilisé aussi bien sous la forme de baguette à fumer que dans la forme non fumée.

Cependant, un individu qui a cessé de fumer pendant plus de 10 ans fait baisser légèrement le risque [II]. La toxicité de la cigarette est à prendre en compte tout comme le nombre de cigarettes et la durée d'exposition au tabagisme. Les cigarettes locales, non conformes aux normes internationales, émettent un taux élevé de goudron et de nicotine et peuvent ainsi présenter un risque élevé. En effet le «Toombak »' est un produit de tabac fermenté et séché contenant du bicarbonate placé dans le sulcus labial et principalement consommé au Soudan et des pays de l'Est [12]. II est fortement contaminé par des micro-organismes qui contribuent à la carcinogenèse [II].

Le khat est un stimulant psychoactif dérivé des feuilles de la plante Catha edulis, qui est un arbuste à feuilles persistantes en fleurs indigène en Afrique de l'Est et dans certaines parties du Moyen-Orient [12]. Le khat (ou Miraa comme on l'appelle au Kenya) détient une importance culturelle, en particulier en Afrique de l'Est et la péninsule arabique, avec une consommation croissante dans le monde de la diaspora. Les effets indésirables systémiques et oraux de la consommation de Khat sont bien documentés, bien qu'il ne semble pas fortement cancérigène pour certains auteurs [13].

Les lésions blanches potentiellement malignes telles que celles induites par le khat (la leucoplasie) ont été décrites chez les mâcheurs avec une prévalence plus élevée chez ceux qui consomment simultanément du tabac et de l'alcool [I4].

Une grande partie de la population ethnique indienne en Afrique (Kenya, Afrique du Sud notamment) consomme toujours de la noix d'arec, généralement incorporée dans une chique de bétel contenant du déchiqueté tabac, des produits parfumés et des chaux éteintes (Paan masala). En 1993, 93\% des femmes indiennes en Afrique du Sud mâchaient la noix d'arec [15]. L'effet cancérigène de la mastication chronique de la chique de bétel ou de la noix d'arec seule a été bien documenté, en particulier dans le sous-continent indien, et les produits d'arec sont maintenant considérés comme un agent cancérigène humain de classe I par le Centre International de Recherche sur le Cancer (CIRC) [16]. Une autre substance potentiellement associée au risque de cancers de la cavité orale est la noix de cola, un stimulant très utilisé dans de nombreuses régions forestières [17].

\section{Consommation d'alcool}

La consommation d'alcool est un facteur de risque indiscutable dans les cancers plus particulièrement des VADS. En Afrique Subsaharienne, cette pratique reste de mise avec une certaine variation géographique du type d'alcool. Elle peut être sousdéclarée dans les communautés où la consommation d'alcool est limitée [5]. En Afrique du Sud, où boire de l'alcool se fait dans le cadre de festivals et de célébrations le plus souvent, les cancers oraux sont très souvent en rapport avec la consommation d'alcool [18]. Comme le confirme une étude prospective en Inde qui révèle que la consommation d'alcool augmente l'incidence de $49 \%$ parmi les utilisateurs actuels et $90 \%$ chez les anciens buveurs. Cela pourrait être dû à l'effet résiduel de la consommation d'alcool ou ceux qui ont abandonné l'habitude en raison de maladie grave. La consommation de boissons alcoolisées était associée à la survenue de cancers oraux chez les hommes $(O R=2,2)$ mais il n'en a pas été de même chez les femmes [10]. En effet les femmes seraient moins consommatrices d'alcool. Le risque augmente avec le nombre de boissons consommées en une semaine $[3,10]$. L'alcool a un effet synergique avec le tabac à mâcher et à fumer [8, 19-2I].

\section{Régime alimentaire}

Le régime alimentaire est variable d'un peule à un autre. La complexité du régime rend difficile l'évaluation du rôle des composants alimentaires dans le développement du cancer. Des recherches ont été menées en termes d'évaluation de régime alimentaire et nutritionnel. II n'existe pratiquement pas d'études épidémiologiques dans les pays subsahariens concernant cet aspect. Quelques études ont pu montrer une relation avec les cancers oraux [22-24]. Ailleurs, les résultats des analyses factorielles de l'alimentation et les cancers oraux menés en Indonésie et en Malaisie ont montré un risque accru 
observé avec une consommation élevée de combinaison de viande, produits laitiers fermentés et aliments salés. Il en est de même pour les produits traditionnels à savoir l'amidon et certains boissons locaux. Cependant, un effet protecteur a été observé avec un régime riche en fruits et légumes après ajustement selon les habitudes [25]. L'effet protecteur des fruits et légumes sur les cancers oraux est sans équivoque. Le risque de développement de cancer pour les non-végétariens est plus élevé que les végétariens de $85 \%$ [26]. Cela pourrait être attribué à une exposition réduite aux hydrocarbures aromatiques polycycliques (HAP) chez les non-végétariens par rapport aux végétariens et ainsi, contribuer à l'augmentation du risque de cancer [27].

\section{Infections au HPV et au VIH}

Une infection persistante par des génotypes à haut risque de HPV est maintenant identifié comme un facteur étiologique majeur pour la partie postérieure de la base de la langue, la région amygdalienne et la région oro-pharyngée. Le fardeau du cancer lié à HPV en Afrique est principalement le cancer du col de l'utérus mais aussi un certain nombre de cancers du cou, de l'ordre de $10 \%$ en Afrique du Sud [28]. La partie ouest de l'Afrique Centrale et le Soudan ont des taux élevés de cancers des VADS, probablement liée à une augmentation des infections liés au HPV [29].

Les HPV et le VIH ont une synergie d'action au niveau moléculaire, cellulaire et clinique [27] et sont fréquemment cotransmis. II en est de même pour les risques de cancer dus au virus de l'herpès humain et au lymphome hodgkinien chez les patients atteints du VIH/SIDA [30]. Cela n'a pas encore été établi pour le cancer squameux buccal en Afrique Subsaharienne. Les patients atteints des cancers des VADS et infectés par le VIH en Afrique Subsaharienne peuvent être plus jeunes. Mais avec la consommation de tabac et d'alcool, les conséquences peuvent être plus marquées [3I, 32]. Cependant, ces hypothèses sont faites sur des données limitées. L'étude sur les données SA-NCR (South African National Cancer Registry) collectées entre 1996 et 2002 [33, 34], a tenté de déterminer si l'épidémie de VIH/SIDA en Afrique du Sud aurait pu augmenter l'incidence et/ou réduire l'âge d'apparition du cancer squameux buccal.

La tendance légèrement à la baisse du TASI (Temporal Analysis of Spheroid Imaging) des cancers de la cavité orale suggère que jusqu'en 2002, l'infection par le $\mathrm{VIH}$ avait eu peu ou pas d'influence stimulante sur le taux d'incidence du carcinome épidermoïde buccal en Afrique du Sud. Les répartitions par âge entre 1996 et 2002 étaient également calculées et illustrées pour les hommes et les femmes [30].

II peut avoir des taux croissants de cancers liés au HPV dans les décennies à venir. La spéculation sur le rôle croissant du HPV dans la survenue du cancer de l'oropharynx en Afrique est importante, en particulier dans les régions où le $\mathrm{VIH}$ est très répandu et où les personnes infectées par le $\mathrm{VIH}$ peuvent avoir une augmentation des persistances de souches de HPV oncogènes [34]. Pourtant, l'infection réplicative active du HPV n'a pas été bien décrite dans HNSCC (Head and Neck Squamous Cell Carcinoma) et les cancers oraux en Afrique Subsaharienne à l'exception de quelques études. On peut citer celle faite en 2010 par Jalouli et al [35] qui a montré que $25 \%$ des 217 échantillons de carcinome épidermoïde de la cavité oropharyngée et/ou buccale au Soudan étaient positifs pour le HPV. Mais aussi avec l'étude de Woto Gaye et al [36], avec 38 cas soit $(42,2 \%)$, la positivité du HPV a été rapportée par soussite anatomique.

\section{Facteurs sociaux}

Il a été montré que les facteurs de risque sociaux suivants peuvent avoir des associations avec les cancers oraux: la pauvreté, la pollution de l'air intérieur, le manque d'éducation générale et une population ignorante, l'inaccessibilité aux soins de santé bucco-dentaire, le manque de professionnels de la santé bucco-dentaire, en particulier en milieu rural, etc. [34]. Tous ces facteurs et qui influent sur l'incidence des cancers de la cavité orale devraient être bien pris en compte dans la prévention [37].

\section{Besoins de prévention primaire et de diagnostic précoce}

Un déficit de connaissances spécifiques d'une cohorte d'étudiants dentistes au Nigéria sur les premiers signes des cancers de la cavité orale a été identifié et seulement $65 \%$ de ces étudiants de premier cycle croyaient au dépistage opportuniste régulier de la maladie [38]. Il y a un réel besoin de sensibilisation et de formation de tous les professionnels de la santé et des populations pour éviter les facteurs de risque et reconnaitre les premiers symptômes de cancer de la cavité orale [22]. II en est de même de la recherche sur le rôle de l'infection au HPV dans les cancers de la cavité orale et de l'oropharynx en Afrique Subsaharienne ceci grâce à des études moléculaires.

\section{CONCLUSION}

Les résultats rapportés dans cette étude montrent qu'au-delà de l'alcool et le tabac, plusieurs autres facteurs sont associés à la survenue des cancers de la cavité orale en Afrique Subsaharienne notamment les facteurs génétiques. Si la prise de conscience des populations vis-à-vis de ces facteurs associés est effective ainsi que le respect des mesures préventives, on pourrait réduire considérablement l'incidence et de mortalité dues à cette maladie en Afrique Subsaharienne. Il y a nécessité de mener des études analytiques ou expérimentales avec des méthodologies structurées pour des résultats plus probants.

\section{CONFLITS D'INTERET}

Les auteurs n'ont déclaré aucun conflit d'intérêts.

\section{REFERENCES}

I. Globocan 2018: estimates of incidence and mortality worldwide for 36 cancers in 185 countries. https://www.uicc.org/news/global-cancer-dataglobocan-2018. Consulté le 10// I/2020.

2. Leroux RJ, Poucet P. Cancer de la langue. Actualités de carcinologie cervico- facial : Paris ; Masson, 1995. https://www.cancer.ca/fr-ca/cancerinformation/cancer type/oral/risks/?regio. Consulté le I 2/ I /2020.

3. Muwonge R, Ramadas K, Sankila R. Role of tobacco smoking, chewing, alcohol drinking in the risk of oral cancer in Trivandrum, India: a nested case-control design using incident cancer cases. Oral Oncol 2008;44(5), 446-54.

4. Parkin DM, Bray F. Evaluation of data quality in the cancer registry: principles and methods. Part II: completeness. Eur J Cancer. 2009; 45: 756-764. 
5. Faggons E. Human papillomavirus in head and neck squamous cell carcinoma: A descriptive study of histologically confirmed cases at Kamuzu Central Hospital in Lilongwe, Malawi. Mal Med J. 2017;29(2):142-145.

6. Phipps, Warren. Oral HHV-8 Replication Among Women in Mombasa, Kenya. J Med Virol. 2014; 86(10): 1759-1765. doi:10.1002/jmv.2394I.

7. Blot WJ, Fraumeni JF. Geographic patterns of oral cancer in the United States: Etiologic implications. Journal of Chronic Diseases. 1977;30(I I):745-57.

8. Osman TA, Satti AA, Boe OE, Yang YH, Ibrahim SO, Suleiman AM. Pattern of malignant tumors registered at a referral oral and maxillofacial hospital in Sudan during 2006 and 2007. J Cancer Res Ther. 2010;6(4):473-7.

9. Faggons CE, Mabedi CE, Liomba NG, Funkhouser WK, Chimzimu F, Kampani $C$ and al Human papillomavirus in head and neck squamous cell carcinoma: A descriptive study of histologically confirmed cases at Kamuzu Central Hospital in Lilongwe, Malawi. Malawi Med J. 2017 Jun;29(2):142145.

10. Balaram P, Sridhar H, Rajkumar T. Oral cancer in southern India: the influence of smoking, drinking, paanchewing, oral hygiene. Int J Cancer. 2002; 98:440445.

II. Babiker T, Tasneem MB, Khansa AO, Safa AM, Matab $A$ et al. Oral Cancer Awareness Among Dental Patients in Omdurman, Sudan: a crosssectional Study. BMC Oral Health 2017;17:69.

12. Faggons CE, Mabedi CE, Liomba NG, Funkhouser WK, Chimzimu F, Kampani $C$ and al Human papillomavirus in head and neck squamous cell carcinoma: A descriptive study of histologically confirmed cases at Kamuzu Central Hospital in Lilongwe, Malawi. Malawi Med J. 2017 Jun;29(2):142145.

13. Balaram P, Sridhar H, Rajkumar T. Oral cancer in southern India: the influence of smoking, drinking, paanchewing, oral hygiene. Int J Cancer. 2002; 98:440445.

14. Al-Hebshi NN, Alharbi FA, Mahri M. Differences in the bacteriome of smokeless tobacco products with different oral carcinogenicity: compositional and predicted functional analysis. Genes (Basel) 2017; 8(4): 106-120.

15. Balint E, Falkay G, Balint GA. Khat a controversial plant. Wiener Klinische Wochenschrift 2009; 12I: 19-20.

16. Al-Motarreb A, Al-Habori M and Broadley K. Khat chewing, cardiovascular diseases and other internal medical problems: the current situation and directions for future research. J Ethnopharmacol 2010; 132: 540-548.

17. Otoh EC, Johnson NW, Olasoji HO, Danfillo IS, Adeleke OA. Intra oral carcinomas in Maiduguri, north eastern Nigeria. https://doi.org/10.1 I I //j.160 I0825.2005.01 I34.x.

18. Tagba E, Sy A. Aspects diagnostiques et résultats du traitement chirurgical des tumeurs maxillo- madibulaires : à propos de 23 cas. J Afr Cancer. 2014; 6: 228-234.

19. Toumkara. Problématique de l'accès aux médicaments anticancéreux au Mali, Université de Bamako, Mali. Thèse de médecine $\mathrm{N}^{\circ} 054.07$ année 2007.

20. Dieng MM. Cancers de la cavité buccale : à propos de I45 cas à l'institut Joliot-Curie de Dakar. Posters / Cancer/Radiothérapie. 2012 ; $16: 524-581$.

21. Gad AH. Impact of toombak dipping in the aetiology of oral cancer: age-exclusive hazard in the Sudan. J Cancer Res Ther 2007; 3(2): I27-130.

22. Pacella-Norman R, Urban M, Sitas F. Risk factors for oesophageal, lung, oral and laryngeal cancers in black South Africans. Br J Cancer 2002; 86: I75I-I756.

23. Akinmalodum V. Evaluation of the histopathology of orofacial lesions in a North-East Nigerian tertiary centre. Ann Afr Med. 2014 Jan-Mar; 13 (I):29.

24. Baba ND. Evaluation de la fonction ventilatoire par mesure du débit expiratoire maximum lors d'une enquête sur le tabagisme dans le milieu estudiantin dakarois. UCAD, Dakar, Sénégal. Thèse: Méd.1989 $\mathrm{n}^{\circ} 02189$.

25. Merchant A, Husain SSM, Hosain M. Paan without tobacco: an independent risk factor for oral cancer. Int J Cancer 2000;86: I 28-3I.

26. Amtha R, Zain R, Razak IA. Dietary patterns, risk of oral cancer: a factor analysis study of a population in Jakarta, Indonesia. Oral Oncol; 2009; 45: 49-53.

27. The Global Cancer Observatory - IARC. All cancers. Source: Cancer incidence and mortality statistics worldwide and by region. Central America. March, 2019.

28. Adeline $T$. Les régimes végétariens sont-ils réellement bénéfiques pour la santé ?. Sciences pharmaceutiques. 2016. ffhal-01770800f. https://hal.univ-lorraine.fr/hal01770800/document. Consulté le 20 novembre 2020.

29. Bruni L, Barrionuevo-Rosas L, Albero G. ICO Information Centre on HPV and Cancer (HPV Information Centre). Human Papillomavirus and related diseases in South Africa. Summary Report 15 December www.hpvcentre.net/statistics/reports/ZAF.pdf (2016). Consulté le I2/12/2019.

30. Piette E, Reychler H. (Eds). Traité de Pathologies buccale et maxillo-faciale. Bruxelles, De BoeckUniversité, 199I, 1977.

3I. Butt FMA, Chindia ML, Rana F, Machigo FG. Pattern of head and neck malignant neoplasms in HIV-infected patients in Kenya. Int. J. Oral Maxillofac. Surg. 2008; 37: 907-9II.

32. Beachler DC, D Souza G. Oral HPV infection and head and neck cancers in HIV-infected individuals. Curr Opin Oncol 20I3; 25(5): 503-5I0.

33. Onyango JF, Omondi BI, Njiru A. Oral cancer at Kenyatta National Hospital, Nairobi. East Afr Med J 2004; 8I (6): 318-32I.

34. Jalouli J, Jalouli MM, Sapkota D. Human papilloma virus, herpes simplex virus and Epstein Barr virus in oral squamous cell carcinoma from eight different countries. Anticancer Res 2012; 32(2): 57I-580. 
35. Bougar F. Cancers de la cavité buccale étude épidémiologique et clinique rétrospective à propos de 70 cas. À Marrakech à l'université CADI AYYAD (Maroc). Thèse en médecine $\mathrm{N}^{\circ}$ 69, 17 Année 2017.

36. Woto-Gaye G, M'Farrej MK, Doh K. Les papillomavirus humains : un autre facteur de risque des carcinomes des voies aérodigestives supérieures. Bull. Soc. Pathol. Exot. 2016;109:160-164.

37. Jalouli J, Ibrahim SO, Sapkota D. Presence of human papilloma virus, herpes simplex virus and epstein-barr virus DNA in oral biopsies from Sudanese patients with regard to toombak use. J Oral Pathol Med 2010; 39(8): 599-604.

38. Van Wyk CW, Stander I, Padayachee A. The areca nut chewing habit and oral squamous cell carcinoma in South African Indians. A retrospective study. S Afr Med J 1993; 83(6): 425-429.

39. Stein L, Urban MI, O'Connell D, Yu XQ, Beral V, Newton R, Ruff $P$ and al. The spectrum of human immunodeficiency virus-associated cancers in a South African black population: results from a case-control study, 1995-2004. Int J Cancer. 2008; I 22(I0):2260-5. doi: 10.1002/ijc.2339I. PMID: I824I034.

40. Boy Sonja. HPV detection in primary intra-oral squamous cell carcinomas - commensal, aetiological agent or contamination? J Oral Pathol Med 2006; 35: 86-90.

41. Seydi A Ba. Etude du polymorphisme du codon 72 du gène $P 53$ comme facteur de risque dans les cancers de la cavité buccale au Sénégal. Université Cheikh Anta Diop, FMPO. Thèse de pharmacie $\mathrm{N}^{\circ} 0147.14$ année 2014.

42. Butt F M A, Chindia M L, Rana F. Oral squamous cell carcinoma in human immunodeficiency virus positive patients: clinicopathological audit. The Journal of Laryngology \& Otology 2012; 126: 276-278.

43. Lawal. AO. Social profile and habits of oral cancer patients in Ibadan. Afr J Med Med Sci. 20 I I; 40 (3): 247-5I.

44. Davidson CL. Prevalence of oral and oropharyngeal human papillomavirus in a sample of South African men: A pilot study. 2012; 16:524-58I.

45. Bambara Augustin T. Cancers de la cavité buccale : affection à prédominance féminine à Ouagadougou. Med Buccale Chir Buccale 2015;21:61-66.

46. Bassey GO, Osunde OD, Anyanechi CE. Tumeurs maxillo-faciales et lésions analogues à des tumeurs dans un hôpital universitaire nigérian: analyse rétrospective de onze ans. Afr Health Sci. 2014 ;14 (I): 56-63. 
ANNEXES

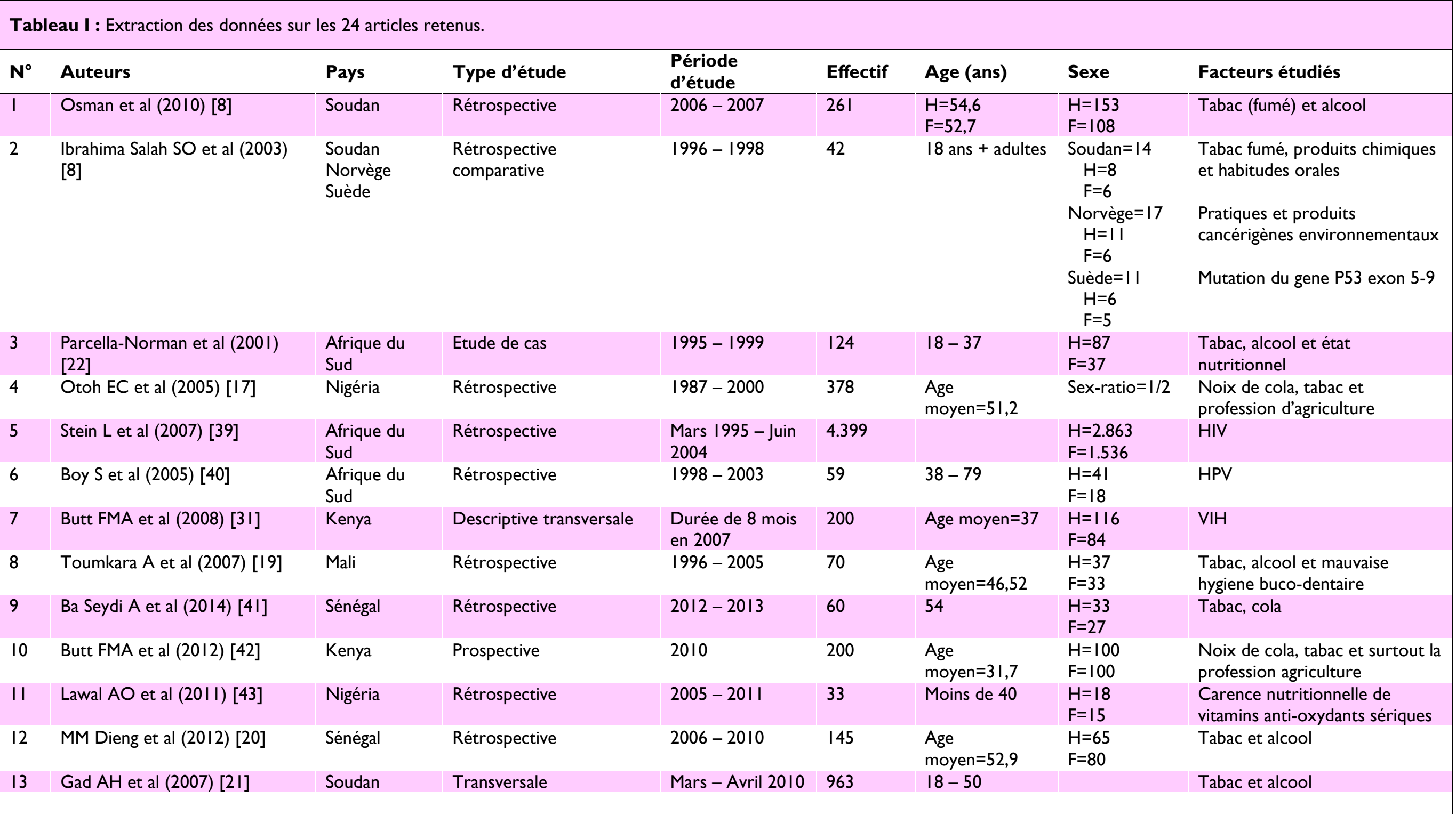




\begin{tabular}{|c|c|c|c|c|c|c|c|c|}
\hline 14 & $\begin{array}{l}\text { Akinmalodum } V \text { et al }(2013) \\
{[23]}\end{array}$ & Nigéria & Rétrospective & $200 I-2007$ & 199 & $20-40$ & $\begin{array}{l}\mathrm{H}=108 \\
\mathrm{~F}=91\end{array}$ & $\begin{array}{l}\text { Facteurs héréditaires, le } \\
\text { tabagisme, une mauvaise hygiene } \\
\text { buccale et une faible } \\
\text { consummation de fruits et de } \\
\text { legumes }\end{array}$ \\
\hline 15 & Tagba E et al (20|3) [18] & Sénégal & Rétrospective & $2004-2012$ & 23 & $\begin{array}{l}\text { Age } \\
\text { moyen=34,5 }\end{array}$ & $\begin{array}{l}H=10 \\
F=13\end{array}$ & HPV \\
\hline 16 & Phipps W et al (20I4) [6] & Kenya & Rétrospective & $2005-2014$ & 40 & Age moyen $=37$ & $\begin{array}{l}\mathrm{H}=0 \\
\mathrm{~F}=40\end{array}$ & HHV-8 \\
\hline 17 & Davidson $C L$ et al (20I4) [44] & $\begin{array}{l}\text { Afrique du } \\
\text { Sud }\end{array}$ & Transversale & $\begin{array}{l}\text { ler trimester } \\
2009\end{array}$ & 1.339 & Age moyen $=34$ & $\begin{array}{l}H=720 \\
F=617\end{array}$ & $\begin{array}{l}\text { HPV oral et oro-pharyngé } \\
\text { serotypes } 16 \text { et } 18\end{array}$ \\
\hline 18 & Bambara A et al (20I5) [45] & Burkina Faso & Rétrospective & $2003-2014$ & 79 & Age moyen $=56$ & $\begin{array}{l}\mathrm{H}=28 \\
\mathrm{~F}=5 \mathrm{I}\end{array}$ & Tabac fumé et maché \\
\hline 19 & Faggons $\mathrm{C}$ et al (2015) [9] & $\begin{array}{l}\text { Afrique } \\
\text { Subsaharienne }\end{array}$ & Revue de littérature & $1990-2013$ & 8.611 & $37-47$ & & $\begin{array}{l}\text { HPV et facteurs } \\
\text { comportementaux aux HNSCC }\end{array}$ \\
\hline 20 & Bassey GO et al (20I5) [46] & Nigéria & Rétrospective & $2000-2013$ & 46 & $4-70$ & $\begin{array}{l}H=28 \\
F=18\end{array}$ & Toombak et tabac joue \\
\hline 21 & Woto Gaye et al (2016) [36] & Sénégal & Rétrospective & $\begin{array}{l}\text { Janvier } 2012- \\
\text { Juin } 2014\end{array}$ & 90 & $\begin{array}{l}\text { Age } \\
\text { moyen }=47,7\end{array}$ & Sex-ratio $=2,5$ & HPV \\
\hline 22 & Baba ND et al (20I6) [24] & Mauritanie & Etude de cas & $2003-2016$ & 3 & $55-63$ & $\begin{array}{l}\mathrm{H}=3 \\
\mathrm{~F}=0\end{array}$ & $\begin{array}{l}\text { Facteurs héréditaires, mauvaise } \\
\text { hygiene buccale et faible } \\
\text { consummation de fruits et } \\
\text { legumes }\end{array}$ \\
\hline 23 & Babiker T et al (20I7) [II] & Soudan & Transversale & 2015 & 500 & $\geq 18$ & $\begin{array}{l}H=327 \\
F=173\end{array}$ & $\begin{array}{l}\text { Usage du tabac sans fumé et } \\
\text { toombak }\end{array}$ \\
\hline 24 & Faggons E et al (2017) [12] & Malawi & Rétrospective & $2010-2014$ & 77 & Age moyen $=52$ & $\begin{array}{l}H=50 \\
F=48\end{array}$ & $\begin{array}{l}\text { Association entre } \mathrm{Pl} 6 \text { et site } \\
\text { tumoral, facteurs de risqué } \\
\text { comportementaux, } \\
\text { caractéristiques et statut } \mathrm{VIH}\end{array}$ \\
\hline
\end{tabular}

\section{$\mathrm{H}$ : Homme}

$\mathrm{F}$ : Femme

VIH : Virus de l'immunodéficience humaine

HPV : Virus du papilloma humain

HHV-8 : Virus herpes humain 8

HNSCC : Head and Neck Squamous Cells Carcinoma 
An official journal of the / Un journal officiel de la "Société Sénégalaise de Cancérologie" (SOSECAN)

Journal homepage: www.africanjournalofoncology.com

Review / Synthèse

DOI: https://www.doi.org/I0.54266/ajo. I.2.42.PPTT9|23

\title{
Breast reconstruction after breast cancer
}

\section{Reconstruction mammaire pour cancer du sein}

\author{
ME. Charfi", S. Ka', A. Dem'. \\ ' Institut Joliot Curie, Dakar, Sénégal.
}

\section{INTRODUCTION}

With an incidence of 47.8 per 100,000 populations, breast cancer is the most common cancer in terms of incidence worldwide in 2020 [I]. In most cases, its treatment involves breast surgery. This surgery can be radical in some cases [2]. This surgery is a mastectomy with axillary dissection or sentinel lymph node biopsy. However, patient satisfaction is not limited to the treatment of the disease but also to the aesthetic aspects of these treatments. Thus, these women are asking for breast reconstruction (BR) which can be instantaneous or delayed. In this review, we have tried to take stock of the different aspects of BR.

\section{BREAST RECONSTRUCTION IN ONCOLOGY}

BR after mastectomy is a breast surgery whose main goal is to improve the psychosocial outcome of the patient. From the announcement of the diagnosis, through systemic treatments, surgery amplifies psychological morbidity [3, 4]. Reconstruction is a functional treatment that has no impact on survival. It should not modify a therapeutic strategy in oncology [5-7]. Several techniques have been developed in recent years. However, there is no consensus on the indications for the different reconstructions. Patient satisfaction is associated with their clinical and cosmetic outcomes [3, 8-II]. However, in general, BR after mastectomy is associated with qualitatively comparable benefits to those observed after breast-conserving surgery [12, 13]. The BR technique varies depending on the technique used. It can be performed either with an internal breast prosthesis or with an autologous flap and its timing varies depending on whether it is performed immediately after the mastectomy (IBR) during the same procedure or delayed (DBR).

\section{BREAST RECONSTRUCTION WITH INTERNAL PROTHESIS}

$\mathrm{BR}$ with internal prosthesis is based on the principle of placing a prosthesis in the retro-pectoral space. This is a relatively simple process; however, skin coverage is the main limitation. It can be immediate or delayed, with or without a flap, with or without progressive tissue expansion [14]. In some cases, a skin preparation is necessary to prepare for the expansion of skin tissue by the underlying prosthesis. On the other hand, this is not the only limit to this type of construction. The other difficulty is breast volume. Indeed, the prostheses placed are generally small and an asymmetry of volume can be noted with the contralateral breast which will require a symmetrization gesture which is necessary in 20 to $60 \%$ of cases [15]. However, postponing the placement of the prosthesis allows a better assessment of the cosmetic result. However, this surgery is not without its risks. The main complications are hematomas, collections, infections, skin necrosis, exposures, perforations, prosthesis dislocations and especially prosthesis retractions. The latter is the main cause of failure of internal prosthetic BR [16]. The risk factors are postoperative hematomas, local sepsis and the subcutaneous positioning of the prosthesis [17]. Therefore, it is recommended to perform rigorous surgical hemostasis, perioperative prophylaxis, the use of acellular matrix and retro-pectoral positioning. The surface of the prosthesis and the filling material have no role in prosthetic retraction. The role of radiotherapy is controversial $[18,19]$.

\section{BREAST RECONSTRUCTION \\ AUTOLOGOUS FLAP}

Given the limits of BR by internal prosthesis, new procedures have emerged. It is autologous flap BR. Several techniques using different flaps have been described [13]. Two main flaps are used: the latissimus dorsi musculocutaneous flap (LDMF) and the transverse rectus abdominis musculocutaneous flap (TRAMF). Regardless of the technique used, the complications of this type of BR are independent of the type of flap and can affect the donor site as the reconstructed site. At the donor site, these are hematomas, collections, chronic pain or paresis. At the reconstructed site, these are ischemic fatty necrosis, skin necrosis, infections, collections or extensive flap necrosis generally requiring a second flap $[6,20]$.

The LDMF is relatively simple and quick to implement. Usually, there are no functional complications associated with the mobilization of this flap. The only limitation on the use of this flap is the stifle of the tissue mobilized. Thus, this flap should be reserved for small BR or in combination with an internal prosthesis. In the latter case, it should be noted that the complications of the two procedures add up without reducing the incidence of prosthetic contractions [3, 21, 22].

The TRAMF offers more possibilities despite being more complex to implement. It allows a large amount of tissue to be mobilized. Thus, it is recommended in large volume BR or in the case of large skin excision. The transversa suprapubic scar is generally better accepted by patients. However, this procedure is associated with a greater risk of bleeding and 
exposes the walls to complications that are sometimes disabling [23]. The main risk factors are the experience of the surgeon, obesity, smoking, history of laparotomy and adjuvant radiotherapy [24].

Whatever the type of flap used, the associated complications are comparable, varying between 10 and 54\%. Partial necrosis, the main complication of flaps, occurs in 0-21.5\% [3].

\section{IMMEDIATE OR DELAYED BREAST RECONSTRUCTION}

Historically, the first BR were performed on women seeking mastectomy at a distance of the first surgery. However, this trend has evolved and women are starting to request immediate $B R$ at the same time as mastectomy: IBR have a better psychological outcome than DBR. Despite this, surgeons prefer DBR over IBR because of the advantages of functional treatment (curative then maintenance) and also allowing the patient to better decide on the type of BR and to better choose [3]. On the other hand, from a psychological point of view, this interval allows the woman to mourn the breast and to better accept her new body image in the long term [25]. On a practical level, an DBR makes it possible to organize better logistically and adapt the BR technique to local conditions following curative treatments [3]. In the absence of external radiotherapy (ERT), the different $B R$ techniques are comparable and satisfactory. However, a history of ERT makes it necessary to adapt the BR technique to the extent of postradiation lesions of the integuments of the chest wall [3].

\section{EXTERNAL RADIOTHERAPY AND BREAST RECONSTRUCTION}

The ERT can be carried out before the BR. The loss of vitality and elasticity of the tissues after this ERT explain the poor results of BR with internal prosthesis. Indeed, the failure rate reaches $80 \%$ [26]. Among the complications, we cite painful expansions, defective projection of the breast volume, impressions and fractures of the ribs [3]. Unlike prosthetic BR, flap BR provide good results after ERT. This effectiveness is explained by the possibility of replacing radiation tissue with healthy non-irradiated tissue. Indeed, TRAMF is associated with excellent results, especially when local conditions are the most unfavorable [3, 27].

However, ERT can be performed after BR. This BR, old or recent, prosthetic or flap, does not interfere with the effectiveness of ERT. It is the aesthetic complications that come to the fore [3]. In the case of an old BR, the results are satisfactory but the aesthetic complications are poorly understood [3]. The most frequent case is an adjuvant ERT after an IBR. This ERT has no impact on the scar, but many studies conclude that it has a negative effect. In fact, the complications and in particular the capsular retractions of internal prostheses seem to be increased [28]. The complication rate can reach $48 \%$, including $15 \%$ capsular retractions [3]. For BR with flap, the published results are contradictory [3].

\section{CONCLUSION}

The psychological effect on women after mastectomy in most cases dictates the performance of BR. Several techniques exist and the timing of these BR is variable. However, a case-by-case assessment makes it possible to best judge the technique and the timing.

\section{CONFLICTS OF INTEREST}

The authors have declared no conflict of interest.

\section{REFERENCES}

I. Cancer Today [Internet]. Cancer Today. 202I [cited I 3 July 202I]. Available from: https://gco.iarc.fr/today/

2. Lembrouck C, Nicolet G, Nguyen A, Tunon de Lara C. État des lieux de la reconstruction mammaire après cancer du sein sur l'île de la Réunion en 2016. Gynécologie Obstétrique Fertilité \& Sénologie. 2019;47(3):297-304.

3. Ananian $P$, Protière $C$, Tallet $A$, Arnaud S, JulianReynier C, Houvenaeghel G. Reconstructions mammaires après mastectomie pour cancer du sein : quelles indications retenir ?. Annales de Chirurgie. 2004;129(4): 192-202.

4. Krueger E, Wilkins E, Strawderman M, Cederna P, Goldfarb S, Vicini F et al. Complications and patient satisfaction following expander/implant breast reconstruction with and without radiotherapy. Intern J Rad Oncol Biol Phys. 200I;49(3):7I3-72I.

5. O'Brien W, Hasselgren P, Hummel R, Coith R, Hyams $D$, Kurtzman $L$ et al. Comparison of postoperative wound complications and early cancer recurrence between patients undergoing mastectomy with or without immediate breast reconstruction. The American Journal of Surgery. 1993; 166(1): I-5.

6. Eberlein T, Crespo L, Smith B, Hergrueter C, Douville L, Eriksson E. Prospective Evaluation of Immediate Reconstruction After Mastectomy. Annals of Surgery. 1993;218(I):29-36.

7. Morrow M. Factors influencing the use of breast reconstruction postmastectomy: a national cancer database study. Journal of the American College of Surgeons. 200I;192(1): I-8.

8. Arora N, Gustafson D, Hawkins R, McTavish F, Cella $D$, Pingree $S$ et al. Impact of surgery and chemotherapy on the quality of life of younger women with breast carcinoma. Cancer. 2001;92(5): I 288-1298.

9. Pandey M, Singh S, Behere P, Roy S, Singh S, Shukla V. Quality of life in patients with early and advanced carcinoma of the breast. European Journal of Surgical Oncology (EJSO). 2000;26(I):20-24.

10. Schover L, Yetman R, Tuason L, Meisler E, Esselstyn C, Hermann R et al. Partial mastectomy and breast reconstruction. A comparison of their effects on psychosocial adjustment, body image, and sexuality. Cancer. 1995;75(I):54-64.

II. Fallowfield LJ. Psychosocial adjustment after treatment for early breast cancer. Oncology (Williston Park). 1990 Apr;4(4):89-97.

12. Al-Ghazal S, Fallowfield L, Blamey R. Comparison of psychological aspects and patient satisfaction following breast conserving surgery, simple mastectomy and breast reconstruction. European Journal of Cancer. 2000;36(I 5):1938-1943.

13. Harcourt D, Rumsey N. Psychological aspects of breast reconstruction: a review of the literature. Journal of Advanced Nursing. 200 I;35(4):477-487. 
14. Radovan C. Breast Reconstruction after Mastectomy Using the Temporary Expander. Plastic and Reconstructive Surgery. 1982;69(2): 195-206.

I5. Sandelin K, Billgren A, Wickman M. Management, morbidity, and oncologic aspects in 100 consecutive patients with immediate breast reconstruction. Annals of Surgical Oncology. I998;5(2): I59-I65.

16. Schuster RH, Kuske RR, Young VL, Fineberg B. Breast reconstruction in women treated with radiation therapy for breast cancer: cosmesis, complications, and tumor control. Plast Reconstr Surg. 1992;90(3):445-52;

17. Yun J, Diaz R, Orman A. Breast Reconstruction and Radiation Therapy. Cancer Control. 2018;25(I): I0732748/879548.

18. Embrey M, Adams E, Cunningham B, Peters W, Young V, Carlo G. A Review of the Literature on the Etiology of Capsular Contracture and a Pilot Study to Determine the Outcome of Capsular Contracture Interventions. Aesthetic Plastic Surgery. 1999;23(3):197-206.

19. Spear S, Onyewu C. Staged Breast Reconstruction with Saline-Filled Implants in the Irradiated Breast: Recent Trends and Therapeutic Implications. Plastic \& Reconstructive Surgery. 2000; 105(3):930-942.

20. Yeh KA, Lyle G, Wei JP, Sherry R. Immediate breast reconstruction in breast cancer: morbidity and outcome. Am Surg. 1998;64(I2): I 195-9.

21. Faucher $A$, Génin Etcheberry $T$, Picot $V$. Reconstruction mammaire après cancer du sein. Bilan d'une expérience de 12 années [Breast reconstruction after breast cancer: a review of a 12 year-long experience]. Ann Chir Plast Esthet. 1997;42(2): I 10-7.

22. Noguchi $M$, Fukushima $W$, Ohta $N$, Koyasaki $N$, Thomas M, Miyazaki I et al. Oncological aspect of immediate breast reconstruction in mastectomy patients. Journal of Surgical Oncology. 1992;50(4):24I-246.

23. Yeh KA, Lyle G, Wei JP, Sherry R. Immediate breast reconstruction in breast cancer: morbidity and outcome. Am Surg. 1998;64(I2): I 195-9.

24. Gulyás $G$. Az emlödaganatok mütéteinek plasztikai sebészeti vonatkozásai. Emlö-helyreállító mütétek saját szövetek felhasználásával [Plastic surgery in the context of surgery for breast cancer. Breast reconstruction using the patient's own tissue]. Orv Hetil. 1995; 136(3): 123-7.

25. Parkes C. Components of the reaction to loss of a limb, spouse or home. Journal of Psychosomatic Research. 1972;16(5):343-349.

26. Collis N, Coleman D, Foo I, Sharpe D. Ten-Year Review of a Prospective Randomized Controlled Trial of Textured versus Smooth Subglandular Silicone Gel Breast Implants. Plastic and Reconstructive Surgery. 2000;106(4):786-79I.

27. Tran N, Chang D, Gupta A, Kroll S, Robb G. Comparison of Immediate and Delayed Free TRAM Flap Breast Reconstruction in Patients Receiving Postmastectomy Radiation Therapy. Plastic and Reconstructive Surgery. 200I;108(I):78-82.
28. Evans GR, Schusterman MA, Kroll SS, Miller MJ, Reece GP, Robb GL, Ainslie N. Reconstruction and the radiated breast: is there a role for implants? Plast Reconstr Surg. 1995;96(5): I I I I-5. 
An official journal of the / Un journal officiel de la "Société Sénégalaise de Cancérologie" (SOSECAN)

Journal homepage: www.africanjournalofoncology.com

Original article / Article original

DOI: https://www.doi.org/I0.54266/ajo.I.2.45.NROO2456

\title{
Giant uterine leiomyoma delivered through the cervix: About three cases in Ouagadougou
}

\section{Léiomyome utérin géant accouché par le col : A propos de trois cas à Ouagadougou}

\author{
N. Zongo', AH. Bagué2, M. Windsouri', PB. Yaméogo', NML. Ouédraogo', J. Sawadogo'.
}

I Centre hospitalo-universitaire Yalgado Ouédraogo de Ouagadougou, Burkina Faso.

2 Pôle chirurgie du centre hospitalier régional de Kaya, Burkina Faso.

${ }^{3}$ Service de chirurgie, CHU Tengandogo, Burkina Faso.

INTRODUCTION: Giant uterine leimyofibromas delivered through the uterine cervix are rare. MATERIALS AND METHODS: We report 3 observations in order to describe our diagnostic and therapeutic approach. RESULTS: Three patients aged 40, 49 and 4I years were seen for intense pelvic pain associated with metrorrhagia and a feeling of pelvic heaviness. The average delay of consultation was three years. They were all multiparous. The gynecological examination revealed a firm tissue mass with a smooth and regular surface of eight $\mathrm{cm}$ on average, occupying the vaginal cavity while respecting the vaginal walls. Speculum examination was not possible because of the size of the mass which was flush with the lower third of the vagina. Magnetic resonance imaging concluded to a myoma delivered through the cervix in all patients. A total hysterectomy was performed. Histology of the total hysterectomy specimen concluded a uterine leiomyoma of the uterus. CONCLUSION: These giant uterine leiomyomas are rare. Magnetic resonance imaging describes them well. The treatment is most often a total hysterectomy in women who do not wish to have pregnant.

KEYWORDS: Giant uterine myomas; MRI; Hysterectomy.

INTRODUCTION : Les léimyofibromes utérins géants accouchés par le col utérin sont rares. MATERIELS ET METHODES : Nous rapportons 3 observations dans le but de décrire notre approche diagnostique et thérapeutique. RESULTATS : II s'agit de trois patientes âgées de 40,49 et $4 \mathrm{I}$ ans reçues pour des douleurs pelviennes intenses associées à des métrorragies et à une sensation de pesanteur pelvienne. Le délai moyen de consultation était de trois ans. Elles étaient toutes multipares. L'examen gynécologique a permis de noter une masse tissulaire ferme, à surface lisse et régulière de huit $\mathrm{cm}$ en moyenne, occupant la cavité vaginale tout en respectant les parois vaginales. L'examen au speculum n'était pas possible à cause la taille de la masse qui affleure le tiers inférieur du vagin. L'imagerie par résonance magnétique a évoqué un myome accouché par le col chez toutes les trois patientes. Une hystérectomie totale a été réalisée chez toutes les patientes. L'histologie de la pièce d'hystérectomie totale a conclu à un léiomyome utérin dans tous les cas. CONCLUSION : Les léiomyomes utérins géants accouchés par le col sont rares. L'imagerie par résonnance magnétique est d'un apport notable dans le diagnostic. Le traitement est le plus souvent une hystérectomie totale chez les femmes non désireuses de grossesse.

MOTS-CLES : Myomes utérins géants ; IRM ; Hystérectomie.

\section{INTRODUCTION}

Les myomes utérins sont les tumeurs les plus fréquentes de l'utérus [I]. Ils représentent $70 \%$ des tumeurs bénignes de la femme [I, 2]. Ils surviennent chez les femmes âgées de 30 à 50 ans $[I, 2]$. Les symptômes les plus fréquents sont constitués par les douleurs et les saignements anormaux de l'utérus dont les hyperménorrhées et les métrorragies. Les facteurs de risque sont représentés par les ménarches précoces, la nulliparité et le phototype mélanoderme [I]. Plus de $96 \%$ des myomes utérins sont de localisation corporéale. Moins de I\% des localisations intéressent le col de l'utérus [I, 2]. Les myomes à localisation cervicale sont de survenue rare [2]. Dans la littérature africaine, les données sur la particularité de ces myomes sont rares et ils sont très souvent rapportés dans des études traitant des léiomyomes utérins en générale [3]. Le diagnostic pré-thérapeutique constitue parfois un défi du fait du polymorphisme clinique [4]. La chirurgie demeure le principal moyen thérapeutique de ces tumeurs utérines bénignes à topographie cervicale [2]. Nous rapportons une série de trois cas de léiomyomes géants accouchés par le col, dans le but de décrire notre approche diagnostique et thérapeutique.

\section{OBSERVATIONS}

Cas I

Mme N.C., 49 ans, femme au foyer a consulté en octobre 2015 pour des métrorragies abondantes. Le début de la symptomatologie remonterait à trois ans marqué par des douleurs pelviennes d'abord intermittentes puis permanentes, intenses et paroxystiques, rebelles aux antalgiques de palier II, requérant de la morphine. Elles étaient accompagnées de métrorragies faites de sang rouge, d'abondance croissante. Par ailleurs, des constipations et de la pollakiurie étaient rapportées. La patiente était multigeste (neuf fois), multipares (sept accouchements). Aucun antécédent personnel de myome ou de cancer, ni de comorbidité n'a été retrouvé. II n'y avait

* Corresponding author: Dr Nayi Zongo, Maître de Conférences Agrégé, Cancérologie Chirurgicale, CHU Yalgado Ouédraogo, Université Joseph KI-ZERBO, Burkina Faso. 
pas d'histoire familial de myome ou de cancer dans la famille. L'examen générale retrouvait une pâleur conjonctivale et palmo-plantaire, une pression artérielle à $100 / 60 \mathrm{mmHg}$ et un pouls à 95 pulsations/min. Une masse pelvienne peu mobile était retrouvée à la palpation hypogastrique. Au toucher vaginal, le doigt butait sur une masse comblant le vagin, ferme, à surface lisse non adhérant aux parois vaginales qu'elle refoule. Au toucher vaginal combiné au palper abdominal, la masse était mobile avec l'utérus. Au toucher rectal, la masse bombait dans le rectum qu'elle comprimait.

L'imagerie par résonnance magnétique (IRM) concluait à un volumineux myome accouché par le col de $15 \mathrm{~cm}$ de grand axe avec un utérus reposant sur le myome telle « la lanterne sur le dôme de l'église saint Paul de Londres » (Figure I). Une anémie avec un taux d'hémoglobine de $7 \mathrm{~g} / \mathrm{dl}$ a été objectivée par le bilan préopératoire et corrigé par une transfusion de sang Isogroupe-isorhésus. Elle a bénéficié d'une laparotomie médiane sous-ombilicale sous anesthésie générale. L'exploration chirurgicale a permis de retrouver des ovaires non tumoraux et un utérus dont le corps était indemne de tumeur et la partie cervicale siège de tumeur à développement endovaginal. II a été réalisé une hystérectomie totale (Figure 2). L'examen anatomopathologique de la pièce opératoire a conclu à un léiomyome cervical de l'utérus. Les suites opératoires ont été simples.

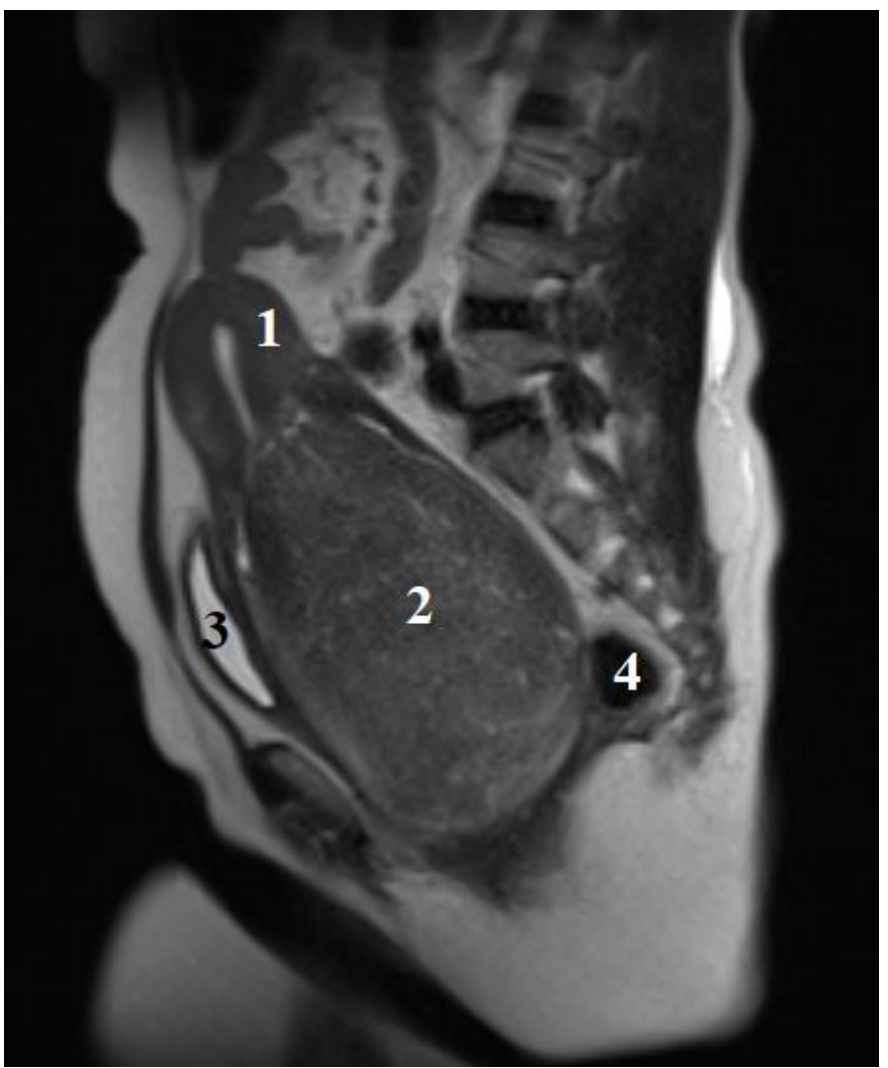

Figue I : Coupe sagittale d'IRM montrant le léiomyome accouché par le col occupant la cavité vaginale. I: Utérus, 2: Myome cervical, 3: Vessie, 4: Rectum.

\section{Cas 2}

Mme B.S., 40 ans, a consulté en Août 2018 pour des métrorragies évoluant depuis environs cinq ans. Il s'agissait de métrorragies d'abord d'abondance minime associées à des douleurs pelviennes, des constipations chroniques et une pollakiurie.

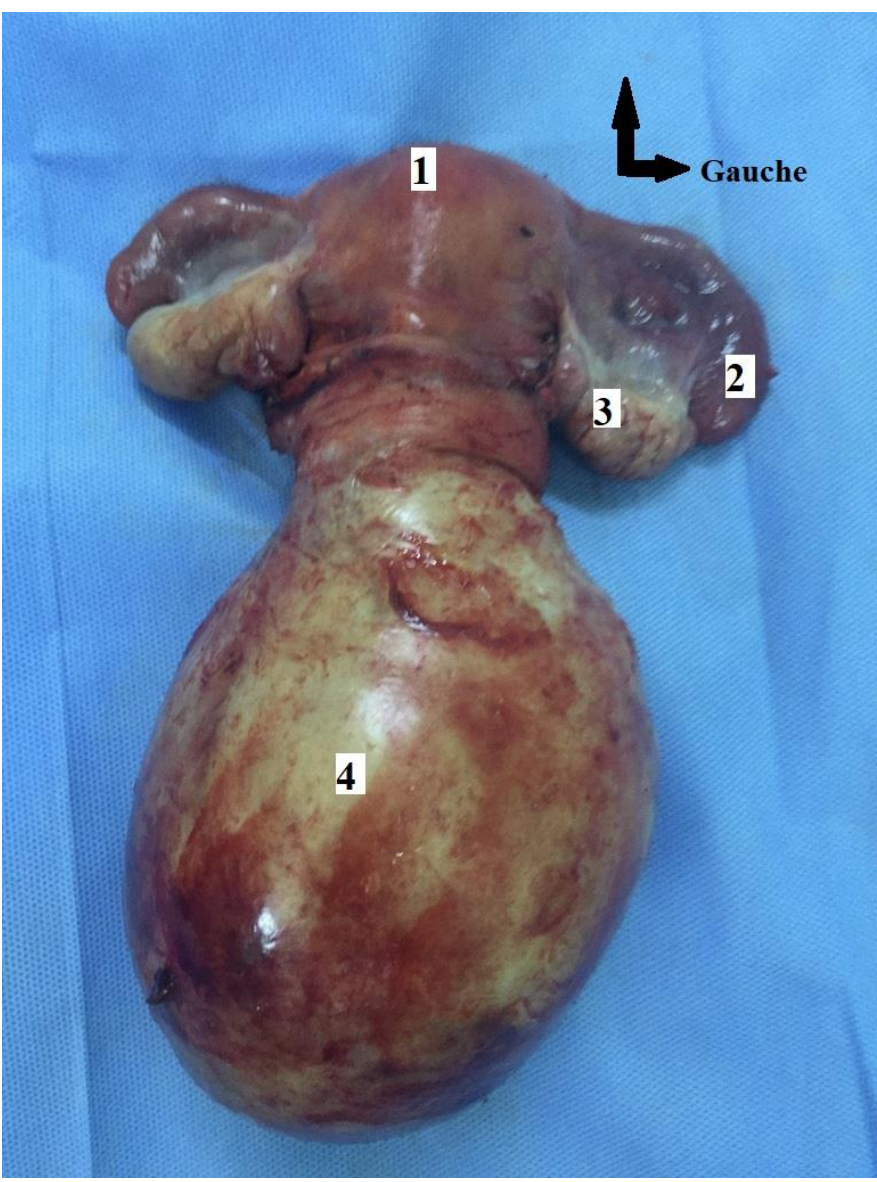

Figue 2 : Pièce opératoire d'hystérectomie et annexectomie bilatérale pour volumineux myome cervical : Aspect en «l lanterne sur le dôme de Saint Paul ». I: Utérus, 2 : Trompe droite, 3 : Ovaire droit, 4 : Myome cervical.

Après recours à un traitement auprès des tradi-praticiens sans succès, elle a consulté en milieu médical pour meilleure prise en charge. Dans ses antécédents gynécologiques, nous retrouvons une ménarche à 14 ans, trois grossesses et trois parités avec un cycle menstruel perturbé du fait des métrorragies. Elle n'avait pas d'antécédents médicochirurgicaux. Aucune histoire familiale de myome ou de cancer n'a été rapportée. A l'admission dans notre centre, elle avait un statut de performance selon l'OMS à 0 et des constantes normales. A l'examen physique, une masse hypogastrique dure, aux contours bien limités, indolore était palpée. Au toucher vaginal, le doigtier se heurtait à une masse dure aux limites nettes, à surface régulière et lisse, non adhérente à la paroi vaginale de sept $\mathrm{cm}$ de grand axe. Les culs-de-sac vaginaux n'était pas perçus. La masse hypogastrique était mobile lors de la mobilisation de la masse endovaginale au toucher vaginal combiné au palper abdominal. Le doigtier ramenait des traces de sang. La tumeur faisait effet de masse sur le rectum au toucher rectal. L'échographie pelvienne a retrouvé un gros utérus siège d'une masse cervico-isthmique peu vascularisée au Doppler. L'IRM notait une masse utérine cervico-isthmique hétérogène a développement endovaginal. Le traitement a été une hystérectomie totale. Les suites opératoires ont été simples.

Cas 3

Mme K.S., 4I ans, a consulté en Mai 202I pour des métrorragies et des douleurs pelviennes évoluant depuis plus d'un an. Elle n'avait pas d'antécédents de cancer dans la famille. 
L'examen clinique a permis de retrouver un statut de performance OMS I. II a été noté une pâleur palmo-plantaire et conjonctivale, une polypnée à 24 cycles/minutes, une tachychardie à 105 pulsations/minutes. La tension artérielle était de $90 / 60 \mathrm{mmHg}$.

Au toucher vaginal, la masse était arrondie avec une surface régulière et lisse. Elle comblait la lumière vaginale. Les parois vaginales étaient régulières. Les paramètres étaient souples. Le taux d'hémoglobine était de $3 \mathrm{~g} / \mathrm{dl}$. L'IRM a retrouvé un utérus siège de multiple masses, dont une cervico-isthmique à développement endocavitaire prolabant dans le vagin (Figure $3)$. La patiente a bénéficié d'une réanimation préopératoire, de transfusion de concentrés de culot globulaire isogroupeisorhésus. Ce qui a permis d'obtenir un taux d'hémoglobine à $10 \mathrm{~g} / \mathrm{dl}$. En peropératoire, l'exploration a mis en évidence un utérus polymyomateux avec le plus gros myome accouché par le col. II a été réalisé une hystérectomie totale avec annexectomie bilatérale (Figure 4). Les suites opératoires ont été simples.

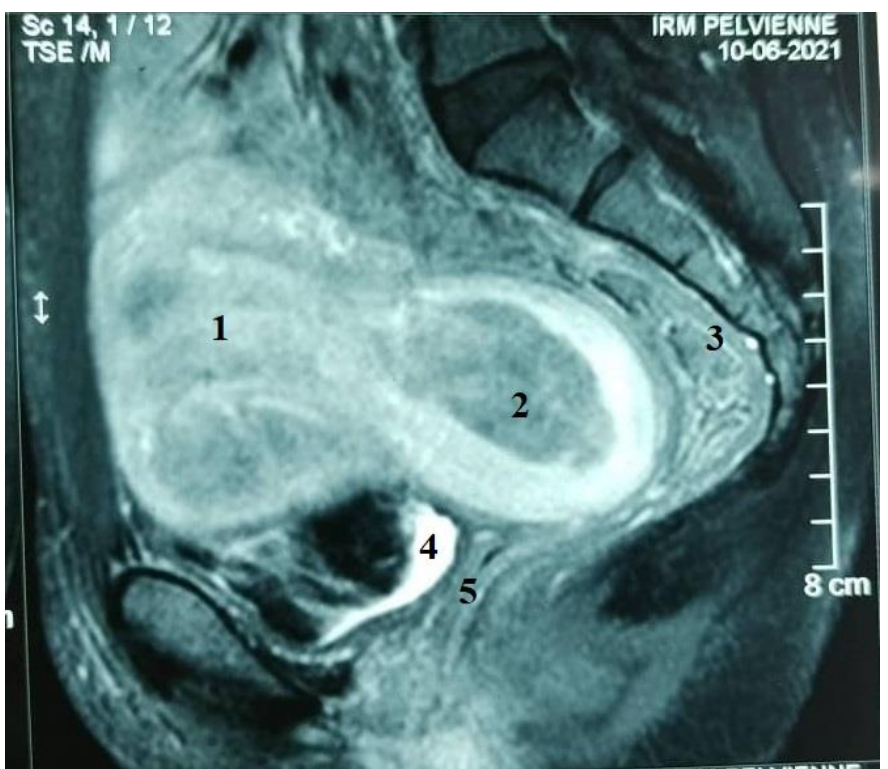

Figue 3 : Aspect IRM en phase T2 d'un utérus polymyomateux, dont un myome accouché par le col (coupe sagittale). I : Utérus polymyomateux, 2 : Myome accouché par le col, 3 : Rectum, 4 : Vessie, 5 : Vagin.

\section{DISCUSSION}

Les léiomyomes utérins, encore appelés «fibromes utérins » ou « myomes utérins », à localisation cervicale représentent une forme topographique rare de ces tumeurs gynécologiques les plus fréquentes $[1,2]$. Ils constituent moins de $2 \%$ des léiomyomes utérins [ $[, 2]$. La pauvreté en fibres musculaires lisses de la partie cervicale par rapport au corps de l'utérus explique en partie cette faible fréquence des léiomyomes cervicaux $[1,2]$. Les facteurs de risque de survenue restent cependant similaires aux léiomyomes utérins en général [I, 2]. Ce sont les facteurs concourant à une hyperoestrogénie (ménarche précoces, nulliparité), les conditions ethnogénétiques (mutation du gène MEDI2, femme noire) et les troubles métaboliques (obésité) [3, 5, 6]. Leur prévalence augmente avec l'âge et atteint son pic dans la quarantaine [I]. Toutes nos patientes avaient un âge compris entre 40 et 50 ans.

Du fait de la situation anatomique du col utérin, les léiomyomes cervicaux quand elles surviennent, sont sources de symptomatologies dominées par les métrorragies et les douleurs pelviennes [2]. Ces douleurs très souvent d'aggravation progressive sont la résultante de modifications physiques comme la pression liée à l'augmentation continue du volume du myome, les déchirures du col consécutives également à la croissance tumorale. En fonction de la taille et du sens de développement sont décrites des symptômes particuliers. Les pollakiuries et les constipations sont fréquentes en cas de léiomyomes cervicaux respectivement à développement antérieur et postérieur [7-9]. Des effets de masse sur le tractus urinaire sont rapportés dans les cas de tumeur à développement latéral responsable d'urétérohydronéphrose [7] mais aussi des présentations cliniques mimant une tumeur ovarienne [4].

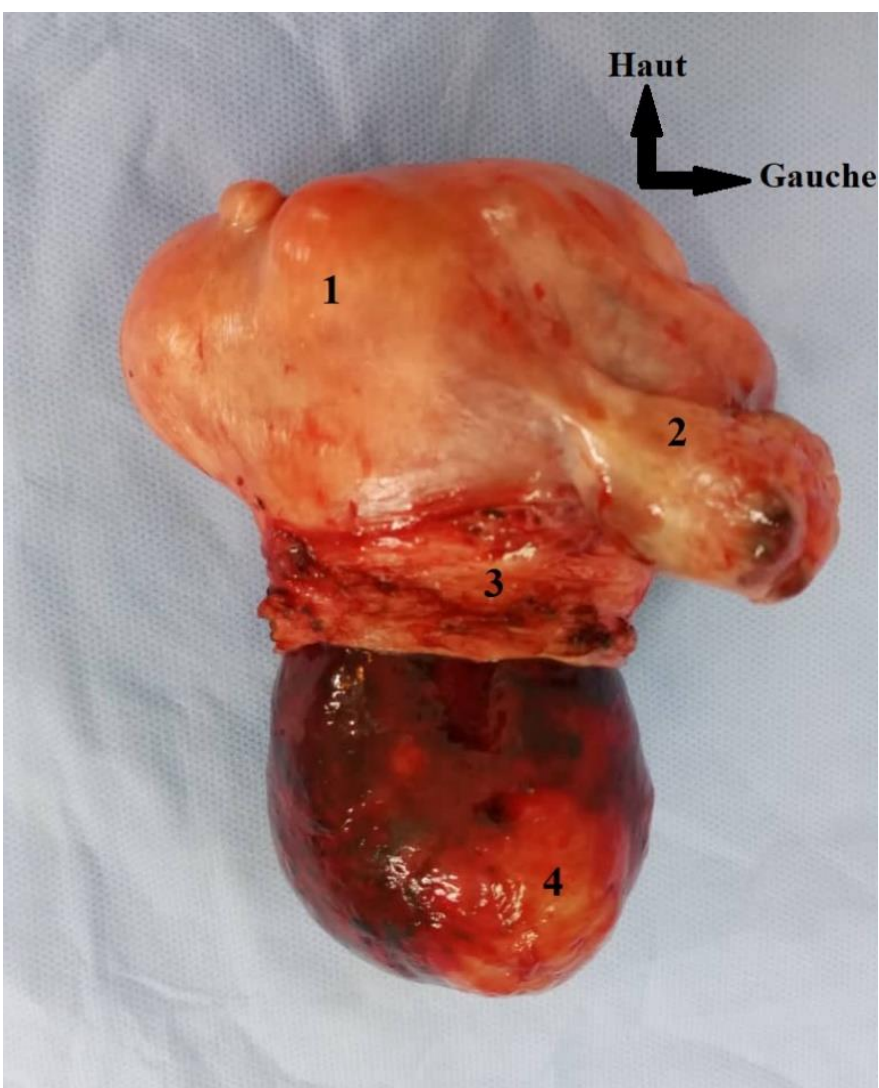

Figue 4 : Pièce opératoire d'hystérectomie totale pour myome accouché par le col. I : Corps utérin (polymyomateux), 2 : Annexe gauche, 3 : Col utérin, 4 : Myome accouché par le col.

Les lésions de petite taille sont facilement objectivées à l'examen clinique comme des tumeurs siégeant sur le col endovaginal. Dans les cas de masses abdomino-pelviennes avec développement endovaginal refoulant l'utérus vers l'abdomen, un examen sous valves pourrait permettre d'évaluer l'état des récessus cervico-vaginaux [7]. II s'agit de tumeurs fermes, à surface luisante régulièrement lisse respectant les parois vaginales telles que retrouvées dans nos observations $n^{\circ} I$ et 3 . La taille maximale retrouvée dans la littérature varie de 9 à 28 $\mathrm{cm}[\mathrm{I}, 4,7]$. Les volumineuses tumeurs au diagnostic sont courantes dans notre contexte. Elles sont corolaires des longs délais de consultation, de l'itinéraire thérapeutique particulière de nos patientes qui passent par les guérisseurs traditionnels. La persistance et l'aggravation des symptômes liés aux métrorragies dictent le recours ultime à la médecine moderne. Le diagnostic différentiel se fait d'une part avec les tumeurs isthmiques, les adénocarcinomes endocervicaux, les sarcomes 
utérins, et les tumeurs ovariennes en cas de léiomyome cervicale latérale pédiculé $[4,7]$.

Les examens radiologiques permettent d'affiner le diagnostic. L'échographie pelvienne en général et particulièrement par voie transvaginale permet de mieux explorer les myomes cervicaux [I, 7]. L'IRM est par excellence l'examen qui permet au mieux de caractériser les lésions utérines, en précisant la taille, la topographie, les nombres exacts, les contours réguliers [I]. Elle nous a permis d'évoquer fortement le diagnostic surtout dans nos cas $n^{\circ} \mathrm{I}$ et 3 .

L'exploration chirurgicale par laparotomie s'impose dans la majeure partie des cas. Elle permet dans la majorité des cas de confirmer l'origine cervico-utérine de la tumeur, et d'évaluer la disposition des organes pelviennes dans un contexte de distorsion de l'anatomie régionale [2, 4, 10]. Ainsi les possibilités thérapeutiques pourront être abordées en optimisant les risques d'incidents opératoires à type de section urétérale ou de perforation vésicale $[I, 7, I I]$. Les voies laparoscopique et transvaginale voire un bistournage sont rapportés pour des cas de myome de moins de $10 \mathrm{~cm}[1,2]$. La prise en charge des léiomyomes cervicaux est presque exclusivement chirurgicale contrairement aux localisations corporéales où un traitement médical peut être souvent entrepris [I, I0]. II peut s'agir d'hystérectomie totale comme dans notre série, où il n'y avait aucun désir de procréation ultérieure. L'examen anatomopathologique de la pièce opératoire permet de confirmer le diagnostic de léiomyome. Le pronostic est bon. Aucune complication immédiate ou à long terme n’a été notée dans notre série.

\section{CONCLUSION}

Les léiomyomes géants accouchés par le col sont rares. Les principaux symptômes demeurent les métrorragies, les douleurs pelviennes et une masse volumineuse endovaginale. L'IRM est d'un grand apport. L'hystérectomie totale constitue le traitement de choix devant des cas symptomatiques chez des patientes non désireuses de grossesse. L'évolution est favorable.

\section{CONFLITS D'INTERET}

Les auteurs n'ont déclaré aucun conflit d'intérêts.

\section{REFERENCES}

I. Vilos GA, Allaire C, Laberge PY, Layland N. Prise en charge des léiomyomes utérins. J Obstet Gynaecol Can. 2016;38(I2S):S550eS576

2. Ferrari F, Forte S, Valenti G, Ardighieri L, Barra F, Esposito V, Sartori E, Odicino F. Current treatment options for cervical léiomyomas: A systematic review of literature. Medicina 2021. 57 : 92. https://www.doi.org/ / 0.3390/medicina 57020092

3. Chalal N, Demmouche A. Profil épidémiologique des fibromes utérins dans la région de Sidi Bel Abbes, Algérie. Pan Afr Med J. 2013 ; 15 :7. Doi : https://www. I0.1 1604/pamj/.2013.15.7.2690

4. Goel N, Seth S. An unusual case of cervical fibroid masquerading as ovarian tumor. J Mid-life Health. 2016;7:144-6.

5. Tiemtoré-Kambou BMA, Baguiyan A, Lamien PD, Koama A, Napon AM, Bamouni YA, Diallo O, Cissé R. Myome, découverte fortuite ou métrorragie : qui dit mieux ? P Afr Med J. 2021;38:388.
6. Kénémé $B$, Ciss $D, K a S$, Mbaye F, Dem A, Sembène M. Uterine fibroids in senegal: polymorphism of medI 2 gene and correlation with epidemiological factors. Ame J Can Res and Rev, 2018,2:4

7. Geetha AM. Lantern on Saint Paul's dôme - A case report of cervical fibroid. Indian Journal of Obstetrics and Gynecology Research. 2021;8(1): I 10-1 I2

8. Kansu-Celik H, Evliyaoglu O, Karakaya BK, Tarlan N, Ozel S, Engin-Ustun Y. Two case of acute urinary retention caused by large cervical leiomyoma with review of litterature. J Exp Ther Oncol. 2019;। 3(I):4I-43.

9. Mihmanli V, Cetinkaya N, Kilickaya, Kilinc A, Köse D. Giant cervical myoma associated with urinary incontience and hydroureteronephosis. Clin Exp Obstet Gynecol. 2015 ; 42(5) : 690-I.

I0. Wong J, Tan GHC, Nadarajah R, et al. BMJ Case Rep 2017: [29 May 202I]. doi:I0.II 36/bcr-2017- 22I408; Consulté le 29 May 202I à 13H40. Disponible sur https://casereports.bmj.com/content/2017/bcr-2017221408.long

II. Kavitha B, Jyothi R, Rama Devi A, Madhuri K, Sachin Avinash K, Murthy SGK. A rare case of central cervical fibroid with characteristic "LANTERN ON TOP OF ST.PAUL” appearance. Int J Res Dev Health. 20। 4;2(I):45-47 
An official journal of the / Un journal officiel de la "Société Sénégalaise de Cancérologie" (SOSECAN)

Journal homepage: www.africanjournalofoncology.com

Original article / Article original

DOI: https://www.doi.org/I0.54266/ajo.1.2.42.PYPNI827

\title{
Dermatofibrosarcoma protuberans at Niamey National Hospital: About I 2 cases
}

\section{Le dermatofibrosarcome de Darier et Ferrand à I'Hôpital National de Niamey : A propos de I2 cas}

\author{
A. Soumaila', Al. Dourahamane', I. Dillé', OS. Galadima², HM. Zaki', G. Hakimi', YD. Harouna'. \\ ' Service de Chirurgie Générale de l'Hôpital National de Niamey, Niger. \\ ${ }^{2}$ Service d'Imagerie Médicale de l'Hôpital National de Niamey, Niger. \\ ${ }^{3}$ Service d'Anatomie et Cytologie Pathologiques, Université Abdou Moumouni de Niamey, Niger.
}

\begin{abstract}
AIM: To report the clinical and therapeutic aspects of dermatofibrosarcoma of Darier and Ferrand (DFS) to the National Hospital of Niamey. MATERIALS AND METHODS: These are 12 patients collected prospectively over three years. RESULTS: It concerns seven men and five women in whom the diagnosis of DFS was made on the basis of histological evidence. The average age was 46.5 years. The tumor was the majority on the trunk (abdominal wall and back) in seven patients or $58.33 \%$. The extension assessment was negative in all patients and all benefited from surgical treatment. This treatment consisted of a wide excision with lateral and deep margins between three and five $\mathrm{cm}$. The recidivism rate is $25 \%$ within 17 months. CONCLUSION: DFS is a rare tumor in Niamey. The trunk is its main location. Surgery is the best treatment. And the recurrence rate is still high.
\end{abstract}

KEYWORDS: Dermatofibrosarcoma; Surgical treatment; Recurrence.

BUT : C'est de rapporter les aspects cliniques et thérapeutiques du dermatofibrosarcome de Darier et Ferrand (DFS) à l'Hôpital National de Niamey. MATERIELS ET METHODES : II s'agit de 12 patients colligés de manière prospective sur trois ans. RESULTATS : Il s'agit de sept hommes et cinq femmes chez qui le diagnostic de DFS a été posé sur la base de preuve histologique. L'âge moyen était de 46,5 ans. La tumeur siégeait majoritaire sur le tronc (paroi abdominale et dos) chez sept malades soit $58,33 \%$. Le bilan d'extension était négatif chez tous les malades et ont tous bénéficiés d'un traitement chirurgical. Ce traitement consistait à une exérèse large avec des marges latérales et profondes comprises entre trois et cinq $\mathrm{cm}$. Le taux de récidive est de $25 \%$ dans un délai moyen de 17 mois. CONCLUSION : Le DFS est une tumeur rare à Niamey. II siège essentiellement au tronc. Son traitement est chirurgical avec un taux de récidive élevé.

MOTS-CLES : Dermatofibrosarcome ; Traitement chirurgical ; Récidive.

\section{INTRODUCTION}

A cheval entre l'inoffensif fibrome et le redoutable sarcome, le dermatofibrosarcome de Darier et Ferrand (DFS) est une tumeur cutanée rare, d'évolution lente caractérisée par un potentiel de récidive locale très élevé [I]. La transformation en sarcome de plus haut grade d'un DFS est rare avec une incidence comprise entre 10 et $20 \%$ [2]. Les métastases sont rares mais non exceptionnelles [3]. Le but de notre étude est de rapporter les aspects cliniques et thérapeutiques du DFS à l'Hôpital National de Niamey en confrontant nos données à celles de la littérature.

\section{MATERIELS ET METHODES}

II s'agit d'une étude prospective qui concerne les cas de DFS diagnostiqués et opérés dans le service de Chirurgie Générale de l'Hôpital National de Niamey de Janvier 2018 à Décembre 2020.

\section{RESULTATS}

Nous avons diagnostiqué et opéré 12 malades en trois ans, il s'agit de sept hommes et cinq femmes dont l'âge varie de 19 à 55 ans avec une moyenne de 46,5 ans. La tumeur était localisée sur la paroi abdominale dans cinq cas, le dos et la cuisse dans deux cas, le cou, le bras droit et la jambe gauche dans un cas chacun (Figure I).

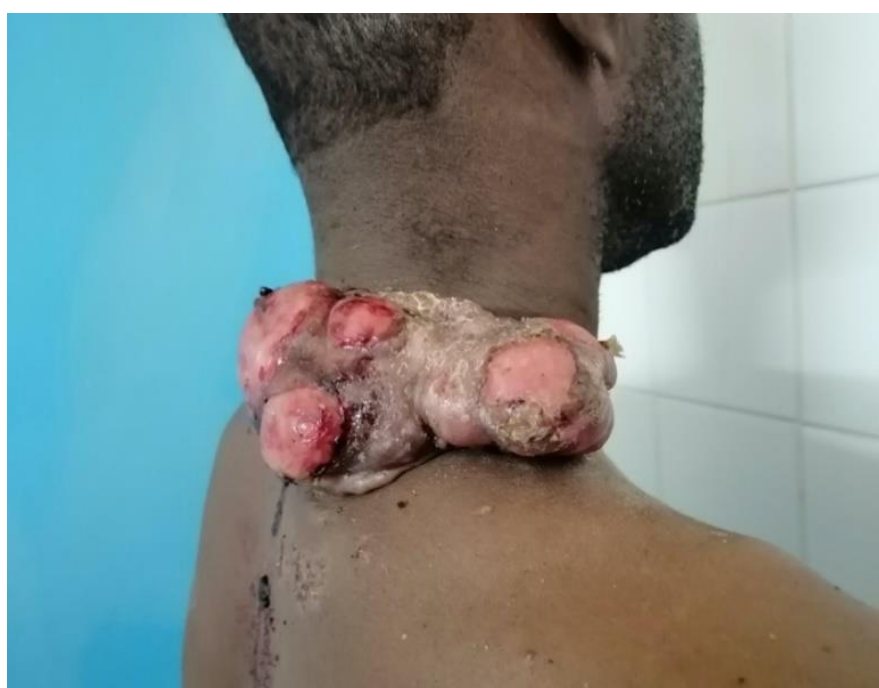

Figue I : Dermatofibrosarcome du cou. 
La taille tumorale variait de six à $21 \mathrm{~cm}$ de grand axe avec un délai de consultation qui situe entre trois et 27 mois. Il s'agissait d'une première récidive après exérèse chez trois patients et d'une deuxième chez quatre autres et d'une cinquième chez un patient. Les autres malades étaient vus pour une première fois. Le délai moyen de récidive de 7,36 mois avec des extrêmes allant de deux à 19 mois. Cliniquement, il s'agissait pour la majorité des cas de masse ferme, irrégulière, multi nodulaires, de couleur chair humaine (Figure 2), indolore et mobile par rapport au plan profond avec quelque fois des croûtes noires par endroit et infectés.

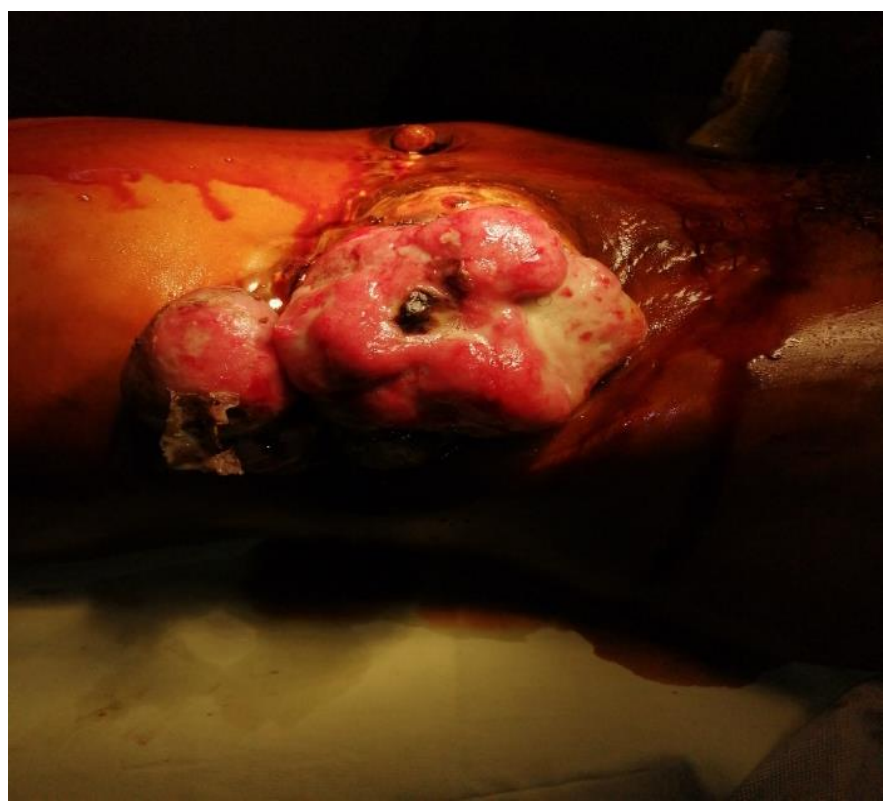

Figue 2 : Tumeur avec un aspect chair de la paroi abdominale.

Tous nos patients avaient bénéficié d'une biopsie avec examen anatomopathologique qui avait évoqué le diagnostic. L'immunohistochimie qui permet de confirmer le diagnostic n'a été réalisé chez aucun malade par manque dans notre contexte. Le scanner thoraco-abdominal réalisé chez tous les malades n'a pas montré de localisation à distance. Nous avons réalisé un traitement chirurgical chez tous les patients. Ce traitement consistait en une exérèse large avec des marges latérales de trois à cinq $\mathrm{cm}$ et en profondeur emportant du tissu macroscopiquement sain. La fermeture cutanée bord à bord avec drainage aspiratif a été possible chez sept patients tandis qu'une cicatrisation dirigée a été conduit chez les autres malades. L'examen anatomopathologique de toutes les pièces opératoires avait confirmé le diagnostic sous réserve de l'immunohistochimie. L'exérèse était complète chez 10 malades alors que la section chirurgicale passait en zone tumorale profonde dans deux cas. Deux malades parmi les cinq chez qui une cicatrisation dirigée avait été décidée se sont compliqués d'infection. Quatre malades étaient perdus de vue après cicatrisation. Parmi les huit autres suivis régulièrement, nous avons noté trois cas de récidive soit $25 \%$ dans un délai moyen de 17 mois. II s'agissait surtout de patients qui avaient consulté pour récidive avec taille tumorale dépassant $10 \mathrm{~cm}$ de grand axe.

\section{DISCUSSION}

A travers une revue de la littérature, qu'il s'agisse des données épidémiologiques, cliniques et thérapeutiques [4-9], nous remarquons que nos résultats sont à beaucoup d'égards comparables à plusieurs séries. Cependant quelques particularités sont à noter.

Du point de vue du diagnostic, dans notre série le diagnostic de DFS a été fait sur la base de preuve histologique uniquement sans immunohistochimie, ni étude cytogénétique. Actuellement le diagnostic est affirmé de manière routinière par l'immunohistochimie qui objective très souvent un marquage positif à l'antigène CD34 (un marqueur non spécifique) mais mieux par l'étude cytogénétique qui retrouve des anomalies génétiques. II s'agit soit d'une translocation des chromosomes 17 et 22, soit de la formation d'un anneau. Cela aboutit à la fusion des gênes COLIAI et PDGFb et à l'expression d'une protéine qui interagit avec le récepteur au PDGF (PDGFR). Ce produit du gène de fusion joue un rôle d'oncogène [8]. C'est la découverte de cette anomalie génétique présente dans $95 \%$ des cas qui permet actuellement d'envisager un diagnostic moléculaire et qui a permis également l'introduction de l'imatinib (Glivec $®$ ) dans le traitement [8].

Du point de vue thérapeutique, la chirurgie constitue la pierre du traitement $[9,10]$. Le DFS est réputé être une tumeur agressive localement avec un potentiel de récidive très élevé. Le challenge c'est de réaliser une chirurgie large avec des marges conséquentes latéralement et en profondeur emportant une barrière anatomique macroscopiquement saine mais surtout de réparer la perte de substance. Certains auteurs rapportent que des marges latérales de trois à cinq $\mathrm{cm}$ et l'exérèse en profondeur d'une zone anatomique macroscopiquement saine permettent d'éviter les récidives. Pourtant des cas de récidives sur ces mêmes marges ont été constatés tandis que d'autres auteurs rapportent une guérison complète sur des marges inférieures à trois $\mathrm{cm}[6,8]$. Pour $O$. Verola, pathologiste, l'important n'est pas de réaliser une exérèse à cinq $\mathrm{cm}$ de ce que l'on voit ou de ce que l'on palpe, mais de passer à un ou deux $\mathrm{cm}$ des marges microscopiques [6]. Ces constatations ont permis l'introduction de la chirurgie micrographique de Mohs dans la prise en charge du DFS. Cette chirurgie a permis non seulement de diminuer considérablement les récidives mais également d'obtenir une réduction des marges d'exérèse dans la prise en chirurgicale de cette maladie. Les résultats obtenus par la chirurgie micrographique sont très intéressants: le taux de récidive locale rapportée pour cette technique est de l'ordre de $2 \%$ en moyenne avec une diminution des marges d'exérèse à deux $\mathrm{cm}$ [II]. Dans notre étude, nous avons réalisé une exérèse chirurgicale avec des marges comprises entre trois et cinq $\mathrm{cm}$ selon les malades et la réparation pariétale a été faite soit par fermeture cutanée bout à bout, soit par cicatrisation dirigée. Ce sont ces mêmes techniques que plusieurs équipes utilisent pour réparer la perte de substance $[I, 7]$.

Le DFS est caractérisé par un index mitotique très bas, ce qui explique la faible réponse à la radiothérapie [7]. Cependant, certains auteurs ont rapporté un meilleur contrôle local par chirurgie large suivie de radiothérapie délivré à 50 ou 60 Gray selon qu'on soit en R0 ou RI, mais il s'agit de courtes séries ne permettant pas de prouver l'efficacité de ce schéma thérapeutique $[9,10]$.

Pour la chimiothérapie, il n'existe pas de protocole claire ayant fait la preuve de son efficacité. Elle est le plus souvent utilisée en palliatif en association avec la radiothérapie [9]. Mais actuellement l'utilisation de l'imatinib constitue un espoir. 
Aucun patient dans notre étude n'a reçu ni chimiothérapie, ni radiothérapie. Nous avons observé deux cas de récidive représentant $16 \%$ de notre échantillon dans un délai moyen de 17 mois. Une des inconnues du problème est que nous ne connaissons malheureusement pas encore avec précision tous les facteurs de risque de récidive. Parmi ces facteurs de risque, la notion de récidives antérieures figure toutefois en première place. Si la tumeur a déjà récidivé, le potentiel de récidive de cette tumeur secondaire ou tertiaire semble très nettement augmenté par rapport à une tumeur primaire, non encore traitée. Toutes choses étant égales par ailleurs, la marge d'exérèse est le deuxième facteur de risque de récidive déterminant. L'analyse de la littérature montre globalement un taux de récidive tumorale qui diminue lorsque la marge d'exérèse chirurgicale augmente. Nous pouvons ainsi retenir les ordres de grandeur approximatifs suivants: $20 \%$ de récidives entre deux et trois $\mathrm{cm}$ de marge, $15 \%$ entre trois et quatre $\mathrm{cm}, 8 \%$ entre quatre et cinq $\mathrm{cm}$. Or ces récidives cliniques correspondent en fait à des exérèses initiales histologiquement incomplètes [I I].

\section{CONCLUSION}

Le DFS est une tumeur à malignité locale dont seule l'exérèse chirurgicale complète assure la guérison. L'introduction de l'imatinib (Glivec $®)$ constitue un espoir dans la prise en charge de cette pathologie.

\section{CONFLITS D'INTERET}

Les auteurs n'ont déclaré aucun conflit d'intérêts.

\section{REFERENCES}

I. Kasse A, Dieng M, Deme A, et al. Les dermatofibrosarcomes de Darier et Ferrand: A propos de 22 cas et revue de la litt érature. Médecine d'Afrique Noire : 1999, 46 (4) :222-227.

2. E. Gerard, P. Guillot, O. Cogrel, M.-S. Doutre, M. Beylot-Barry, B. Vergier. Critères de transformation du dermatofibrosarcome de Darier-Ferrand : implications thérapeutique et pronostique. Annales de Dermatologie et de Vénéréologie, 20I; I42(I2):S552.

3. Hajji Ouafi F Z, Lamchaheb F E, Akazane A, et al. Métastase pulmonaire d'un dermatofibrosarcome de Darier et Ferrand : à propos d'un cas. Ann Derm venereol 20II; Vol 12 (I38):216.

4. FrikhalM.MseddilM.BouchaalaIK et al. Le dermatofibrosarcome de Darier-Ferrand : étude de 49 cas. Ann Derm venereol 20I 7; Vol I 44 (I25):SI7I 172.

5. Nawal H, Ikram B, Kaoutar $Z$ et al. Le dermatofibrosarcome de Darier et Ferrand: à propos de 27 cas et revue de la littérature. Pan African Medical Journal. 2014; 18:280.

6. Traoré SS, Zida M, Baro $F$ et al. Le dermatofibrosarcome de Darier et Ferrand (DFDF). À propos de 7 cas au CHU de Ouagadougou,Burkina Faso. Bull Soc Pathol Exot, 2007, 100(2): 105-106.

7. Nawal Hammas, Ikram Badioui, Kaoutar Znati et al. Le dermatofibrosarcome de Darier et Ferrand: à propos de 27 cas et revue de la littérature. Pan African Medical Journal. 20I4; 18:280
8. Navarrete-Dechent C, Mori S, Barker CA, Dickson MA, Nehal KS. Imatinib Treatment for Locally Advanced or Metastatic Dermatofibrosarcoma Protuberans: A Systematic Review. JAMA Dermatol. 2019;155(3):361-369.

9. Hanan El Kacemi, Abdellah Aissa, Amine Bazine et al. Dermatofibrosarcome de Darier et Ferrand: à propos de 38 cas. Pan Afr Med J. 2014; 19: 274.

10. Llombart B, Serra C, Requena C, Alsina M, MorgadoCarrasco D, Través V, Sanmartín O. Guidelines for Diagnosis and Treatment of Cutaneous Sarcomas: Dermatofibrosarcoma Protuberans. Actas Dermosifiliogr (Engl Ed). 2018; 109(10):868-877.

II. Foroozan M, Sei JF, Amini M, Beauchet A, Saiag P. Efficacy of Mohs micrographic surgery for the treatment of dermatofibrosarcoma protuberans: systematic review. Arch Dermatol. 2012; I48(9): 1055 63. 
An official journal of the / Un journal officiel de la "Société Sénégalaise de Cancérologie" (SOSECAN)

Journal homepage: www.africanjournalofoncology.com

Original article / Article original

DOI: https://www.doi.org/|0.54266/ajo.1.2.52.XRG|93|4

\title{
Management of cutaneous melanoma at the Joliot Curie Institute in Dakar
}

\section{Prise en charge des mélanomes cutanés à l'Institut Joliot Curie de Dakar}

JC. Balegana', S. Ka', D. Diouf', J. Thiam', M. Dieng', PM. Gaye', M. Diop', A. Dem'.

${ }^{1}$ Institut Joliot Curie de Dakar, Sénégal.

\begin{abstract}
AIM: To study the clinical and therapeutic aspects of cutaneous melanoma at the Joliot Curie Institute of Dakar. PATIENTS AND METHODS: We performed a retrospective, descriptive and critical study at the Joliot Curie Institute of Dakar including all histologically confirmed melanoma cases between January 2008 and December 2013. RESULTS: During the study period, 21 cases were managed. The location was plantar in $76 \%$ of cases. Acral type was found in $85.7 \%$ of cases. All patients had a Clark level of IV or higher with a Breslow index of more than two mm. Fourteen patients underwent excision surgery and 12 had inguinal lymph node dissection. The average follow-up was 16 months with an overall survival of $58.7 \%$ at six months and $51 \%$ at one year. CONCLUSION: The majority of patients have benefited from surgical treatment, without prescription of immunotherapy which to date has revolutionized the management of advanced melanoma.

KEYWORDS: Melanoma; Joliot Curie Institute; Dakar.
\end{abstract}

BUT : Etudier les aspects cliniques et thérapeutiques des mélanomes cutanés à l'Institut Joliot Curie de Dakar. PATIENTS ET METHODES : Nous avons réalisé une étude rétrospective, descriptive et critique à l'Institut Joliot Curie de Dakar incluant tous les cas de mélanomes confirmés par l'histologie entre Janvier 2008 et Décembre 20I3. RESULTATS : Au cours de la période d'étude, 21 cas ont été pris en charge. La localisation était plantaire dans $76 \%$ des cas. Le type acral était retrouvé dans $85,7 \%$ des cas. Tous les patients avaient un niveau de Clark supérieur ou égal à IV avec un indice de Breslow supérieur à deux mm. La chirurgie d'exérèse était réalisée chez 14 patients avec curage ganglionnaire inguinale chez 12 patients. La moyenne de suivi était de 16 mois avec une survie globale de $58,7 \%$ à six mois et $51 \%$ à un an. CONCLUSION : La majorité des patients présentait un mélanome acral et a bénéficié d'un traitement chirurgical, aucune immunothérapie qui à ce jour a révolutionné la prise en charge des mélanomes avancés n'a été administrée.

MOTS-CLES : Mélanome ; Institut Joliot Curie ; Dakar.

\section{INTRODUCTION}

Le mélanome cutané est une prolifération maligne au dépend des mélanocytes cutanés situés dans la couche basale de l'épiderme. II est le cancer cutané le plus agressif avec un potentiel métastatique très élevé. Son incidence est en augmentation dans la population caucasienne avec près de 200.000 nouveaux cas chaque année dans le monde [I]. Les facteurs de risque chez les caucasiens sont bien connus. Chez le sujet noir, le mélanome reste rare et les facteurs de risque ne sont pas bien élucidés [2-4]. Certains sont suspectés notamment les traumatismes, la marche pied nu ou encore l'anomalie du gène MCRI. Le principal traitement reste la chirurgie qui permet une guérison pour les stades précoces. Le pronostic reste péjoratif pour les stades avancés et métastatiques. Actuellement avec le développement des thérapies cibles qui améliorent la survie des malades métastatiques mais avec une mortalité non négligeable $[5,6]$.

\section{PATIENTS ET METHODES}

C'était une étude rétrospective descriptive sur six ans qui couvrait la période de Janvier 2008 à Décembre 2013 et portait sur les dossiers des patients présentant un cancer cutané confirmé par l'histologie (biopsie ou pièce opératoire). Les données ont été analyses par Excel(C 2013 et le logiciel
STATA@ version 12. Pour comparer les données, nous avons utilisé le test statistique paramétrique de Chi deux de Pearson. Le seuil de significativité était fixé à $\mathrm{p}=0,05$. Les survies ont été calculées en utilisant la méthode de Kaplan-Meier. Le test LogRank a été utilisé pour comparer les courbes de survie en fonction des différents facteurs pronostiques étudies.

\section{RESULTATS}

Cent-et-trente-et-six cas des cancers cutanés étaient pris en charge dans l'institut dont 21 cas de mélanome retenus pour notre étude, soit $15,4 \%$ des tous les cancers cutanés. L'âge moyen de nos patients était de 60,8 ans avec des extrêmes de 29 ans et 85 ans. Le sex-ratio était de 0,75 . Le délai moyen de consultation de nos patients était de 32,8 mois avec les extrêmes de quatre et 108 mois. Tous nos patients étaient des sujets noirs. Aucun cas d'antécédent familial de mélanome n'a été retrouvé dans notre étude. La tumeur siégeait au niveau plantaire dans $76 \%$ des cas $(n=16)$ (Tableau I). La taille tumorale moyenne était de $7,1 \mathrm{~cm}$ avec des extrêmes de 2,5 et $15 \mathrm{~cm}$. La présence d'ulcération tumorale a été retrouvée chez 15 patients soit $71 \%$ des cas. L'absence de signe d'envahissement ganglionnaire régional était retrouvée chez huit patients soit $38 \%$ des cas. Des ganglions inguinaux étaient retrouvés chez II patients soit 52,4\%. Le mélanome acral 
lentigineux était le type histologique le plus retrouvé chez 18 patients soit $\mathbf{8 5 , 7 \%}$ des cas (Tableau II).

Tableau I : Répartition en nombre et pourcentage selon le siège de la tumeur.

\begin{tabular}{|l|l|l|}
\hline Siège & Nombre & Pourcentage (\%) \\
\hline Plante de pied & I6 & 76 \\
\hline Dorso-lombaire & I & 4,8 \\
\hline Paroi abdominale & I & 4,8 \\
\hline Paroi thoracique & I & 4,8 \\
\hline Hallux droit & I & 4,8 \\
\hline $3^{\text {ème }}$ orteil & I & 4,8 \\
\hline Total & 21 & 100 \\
\hline
\end{tabular}

Tableau II : Types histologiques.

\begin{tabular}{|lll|}
\hline Type histologique & Nombre & Pourcentage (\%) \\
\hline Acral & 18 & 85,7 \\
Nodulaire & 2 & 9,5 \\
SSM & 1 & 4,8 \\
Dubreuilh & 0 & 0 \\
\hline Total & 21 & 100 \\
\hline
\end{tabular}

Toutes les tumeurs présentaient un niveau de Clark supérieur IV. L'indice de Breslow était précisé chez six patients respectivement $2,2 \mathrm{~mm}$, quatre $\mathrm{mm}$, cinq $\mathrm{mm}$, huit $\mathrm{mm}, 10 \mathrm{~mm}$ et $30 \mathrm{~mm}$. Les métastases étaient retrouvées chez huit patients, soit quatre synchrones et quatre métachrones. La chirurgie était réalisée chez I4 patients, soit 66,7 \%. L'exérèse était réalisée chez huit patients avec des marges macroscopiques de trois $\mathrm{cm}$. L'amputation et/ou la désarticulation étaient réalisées chez six patients (Tableau III). Le curage ganglionnaire inguinal était réalisé chez 12 patients, soit $57,1 \%$ des cas.

Tableau III : Répartition selon le type de chirurgie.

\begin{tabular}{|c|c|c|}
\hline Type de chirurgie & Nombre & Pourcentage (\%) \\
\hline Exérèse tumorale & 8 & 57,14 \\
\hline Amputation de la jambe & I & 7,14 \\
\hline $\begin{array}{l}\text { Désarticulation de la } \\
\text { hanche }\end{array}$ & I & 7,14 \\
\hline $\begin{array}{l}\text { Désarticulation de } \\
\text { Chopart }\end{array}$ & I & 7,14 \\
\hline Désarticulation d'orteil & 3 & 21,43 \\
\hline Total & 14 & 100 \\
\hline
\end{tabular}

L'examen histologique des pièces opératoires avait découvert une prédominance de type acral lentigineux chez $57,1 \%(n=8)$. Les marges d'exérèse étaient saines chez huit patients, soit $57 \%$ des cas. Par contre, les marges d'exérèse chirurgicale n'ont pas été précisées chez six patients, soit $43 \%$ des cas. Le nombre moyen de ganglion retrouvé dans le produit de curage était de sept ganglions avec un envahissement dans 4I,7\% (cinq cas). Les complications liées à la chirurgie retrouvées dans notre étude étaient la suppuration locale et le lâchage de suture chez quatre patients, soit $28,6 \%$ des cas. La chimiothérapie était réalisée chez 5 (23,8\% des cas) dont adjuvant chez trois patients et à visée palliative chez deux patients avec comme molécule de base la dacarbazine. La radiothérapie était réalisée chez un patient à visée hémostatique. Pour un suivi moyen de 16 , I mois, la survie globale était de $58,8 \%$ à six mois, de $51,5 \%$ à 12 mois (Figure I).

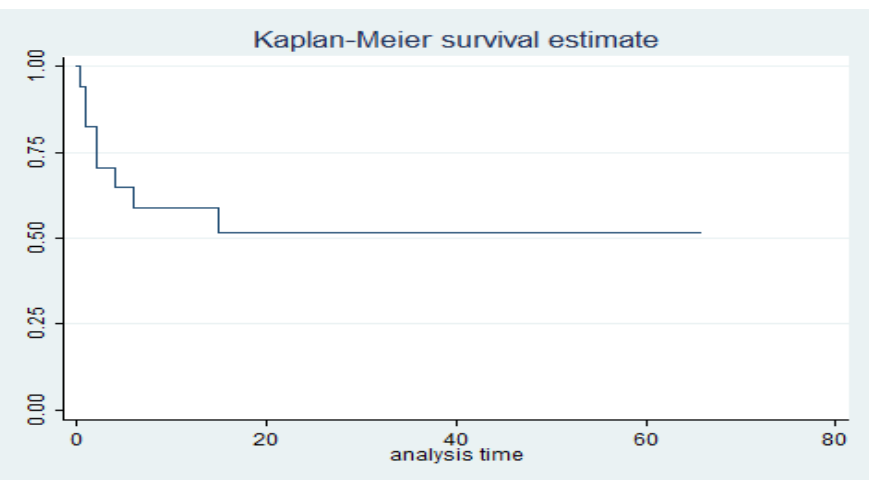

Figure I : Courbe de la survie globale.

Les patients qui ne présentaient pas d'adénopathies semblaient avoir une meilleure survie par rapport à ceux qui avaient des adénopathies (Figure 2).

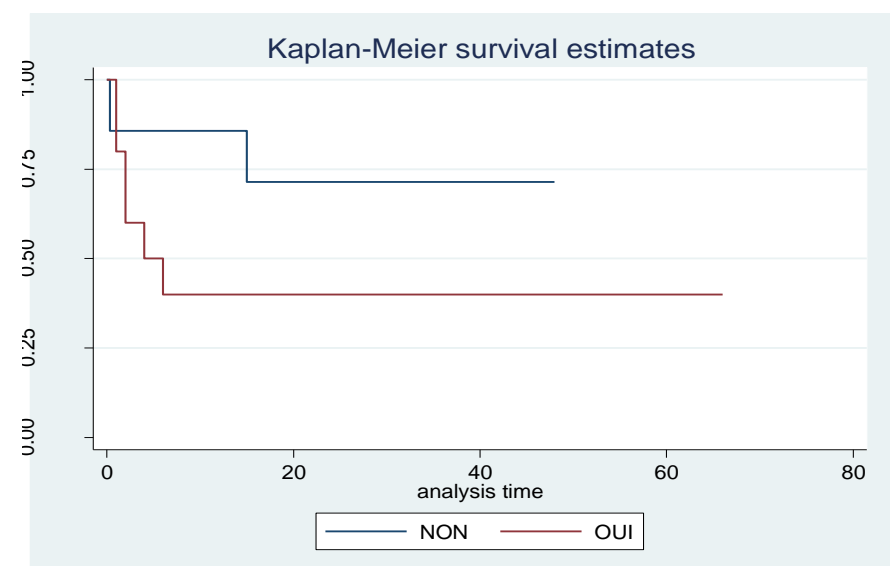

Figure 2 : Comparaison des courbes de survie selon la présence ou l'absence des adénopathies $(\mathrm{Chi} 2(\mathrm{I})=\mathrm{I} .8 \mathrm{I}, \mathrm{Pr}>\mathrm{Chi} 2=0.1783)$.

\section{DISCUSSION}

Dans notre série, les mélanomes représentaient 15,4\% des tous les cancers cutanés avec un sex-ratio de 0,75 . Pitche et al [2] retrouvaient seulement quatre cas de mélanomes soit $5,8 \%$ de même que Saka et al [3] notaient 23 cas de mélanomes soit $10,3 \%$ des cancers cutanés avec un sex-ratio de 0,6 en dermatologie au Togo. Ces différentes études menées en Afrique Noire montrent que le mélanome demeure un cancer rare chez le sujet noir par rapport à la population blanche dans laquelle la fréquence de ce cancer est en augmentation [7, 8]. Cinquante-sept virgule un pour cent de nos patients étaient âgés de plus de 60 ans.

Dans notre travail, la tumeur siégeait au niveau des membres inférieurs (MI) notamment plantaire, dans $85,7 \%$ des cas. Cette situation est observée dans quasiment toutes les séries africaines comme celle de Tarwate et al au Maroc [9], Soua et al en Tunisie [10], Amalia et al au Nigéria [4] ou dans celle de Mohamed et al à Jos au Nigéria [I l].

L'ulcération tumorale, un des facteurs pronostiques du mélanome, était retrouvée dans notre étude dans $71 \%$ des cas 
confirmant un stade évolué et agressif chez la majorité de nos patients. Cette situation peut s'expliquer par un retard de consultation du fait de la localisation plantaire de la tumeur qui est souvent méconnue et négligée par les patients d'un âge avancé.

Dans notre série, le type acral était le plus retrouvé dans $85,7 \%$ ce qui corrobore avec la majorité des séries chez le sujet noir. Contrairement chez le caucasien, le SSM est le type histologique le plus fréquent $[8,12]$.

Tous nos patients présentaient des tumeurs ayant un niveau de Clark supérieur ou égale à IV ce qui confirme le caractère très évolué de la maladie dans notre série.

La chirurgie d'exérèse tumorale était réalisée chez $66,1 \%$ de nos patients et associée à un curage inguinal dans $57,1 \%$ des cas. Ceci implique qu'environ $40 \%$ des patients n'ont pas subi la chirurgie, soit du fait de leur maladie métastatique dans $19 \%$ des cas, soit du fait de la non adhésion au traitement ou encore un problème purement financier. Dans notre étude, nous n'avons pas réalisé de ganglion sentinelle (GS), le curage inguinal était systématique d'autant plus que $52,4 \%$ des patients présentaient des adénopathies inguinales. Cette technique est préconisée pour les tumeurs de plus d'un $\mathrm{mm}$ d'épaisseur en se basant sur les résultats de Morton et al sur le GS que la survie était de $90 \%$ à cinq ans en l'absence de métastase ganglionnaire et de $72,3 \%$ à cinq ans s'il existait des métastases ganglionnaires [13].

Seulement $24 \%$ des patients avaient reçus une chimiothérapie à base de dacarbazine. Aucun de nos patients n'a reçu une immunothérapie ou thérapie ciblée en adjuvant ou en situation métastatique. Cette attitude s'explique du fait de la difficulté d'accès à ces molécules qui coûtent extrêmement chers et sont non remboursables. Dans la recommandation actuelle, l'immunothérapie et la thérapie ciblée notamment les inhibiteurs de BRAFV600E (Vemurafénib®) sont devenus une référence dans la prise en charge des mélanomes avancés et métastatiques. Les perspectives thérapeutiques pour les mélanomes métastatiques seront de combiner les inhibiteurs de BRAF et de MEK avec les résultats supérieurs par rapport aux inhibiteurs de BRAF seul. Plusieurs essais sont en cours avec des résultats encourageants [14]. Actuellement, l'immunothérapie avec les inhibiteurs de check point est devenue un standard dans la prise en charge en première ligne de mélanome métastatique dont notamment les anti PD-I qui ont montré leur efficacité en termes de survie sans progression et survie globale par rapport à l'ipilimumab [15].

\section{CONCLUSION}

Le mélanome cutané sur peau noire est rare mais non exceptionnel avec une agressivité importante et un pouvoir métastatique élevé. La localisation est souvent plantaire méconnu expliquant une consultation tardive avec des tumeurs évoluées voir métastatiques ce qui rend le pronostic péjoratif. L'immunothérapie par les inhibiteurs de check point doit rentrer dans nos pratiques quotidiennes pour les cas avancés et métastasiques. II faut sensibiliser la population sur l'intérêt d'une consultation précoce et toute lésion plantaire suspect doit être excisé en totalité pour un examen histologique.

\section{REFERENCES}

I. Globocan 2012.

2. Pitche P, Tchamdja S, Napo koura G, Bakonde P, Kpodzro K, Tchangaï-Walla K.Les cancers cutanés en consultation dermatologique à Lomé (Togo). Médecine d'Afrique Noire : 1997, 44 (I) :I5-I7.

3. Saka B , Souley Z, Kombaté K, Mouhari-Toure A, Akakpo S, Napo-Koura $G$ et al. Les cancers cutanés au Togo : 223 observations. Med Trop 2010 ; 70(2) : |69-17|.

4. Samalia MAO, Rafindadi AH.Pattern of cutaneous malignant melanoma in Zaria.Nigeria.Annals of African Medecine Society 2006; 5(I):16-19.

5. Graham G. Giles, Bruce K Armstrong, Robert C Burton, Margaret P. Staples, Vicky J. Thursfield.Has mortality from melanoma stopped rising in Australia? Analysis of trends between 193I and 1994,BMJ 1996; 312(7039): I I 2 |- I I 25.

6. Maraninchi $D$, Cerf $N$, Bousquet $P$.Dynamique d'évolution des taux de mortalité des principaux cancers en France, Institut national du cancer. France, Paris Nov 201 I:47-48.

7. Bulliard J, Panizzon R, Levi F.Epidémiologie et prévention du mélanome cutané en suisse.forum Med Suisse 2009, 9(17) :3।4.

8. Mackie RM, Bray C, Vestey J, Doherty V, Evans A, Thomson $D$ et al. Melanoma incidence and mortality in Scotland 1979-2003, British Journal of Cancer (2007);96, 1772 - 1777.

9. Tarwate $M$, Benchikhi $H$, Adarmouch $L$, Benider $A$, Amine $M$, Zamiati $S$. Mélanome épais facteurs de mortalité et de survenu des métastases. Pan African Medical Journal 2014; I8(44) :28I2.

10. Soua Y, Chaabane H, Meziou T, Khemakhem H, Mseddi M.Profil anatomoclinique du melanome dans le sud tunisien Ann derm. 201 I.10.384.

II. Mohammed A, Manasseh A, Mandong B, Edino S.Histopathological study of malignant melanoma in highlanders. Nigerian Journal of Surgical Research 2003; 5:18-22.

12. Howlett A, Dewar R, Morris S.The epidemiology of cutaneous malignant melanoma in Nova Scotia.Can J Plast Surg 2006; I4 (4) : 21 I-2। 4.

13. Morton DL, Thompson JF, Cochran AJ, Mozzillo N, Elashoff R, Essner $R$ et al. Sentinel node biopsy or nodal observation in melanoma. N Engl J Med 2006 ; 355(I3) : I307-1317.

14. Long GJ, Stroyakovskiy D, Gogas H, Levchenko E, Braud F, Larkin J et al.Combined BRAF and MEK Inhibition versus BRAF Inhibition Alone in Melanoma. N Engl J Med 20|4; 37I (20): I877-I888.

15. Carollina R, Georgina V, schachter J. Long-term outcomes in patients (pts) with ipilimumab (ipi)-naive advanced melanoma in the phase 3 KEYNOTE-006 study who completed pembrolizumab (pembro) treatment. J Clinical oncology 2017 ; 35(15)95049504.

\section{CONFLITS D'INTERET}

Les auteurs n'ont déclaré aucun conflit d'intérêts. 
An official journal of the / Un journal officiel de la "Société Sénégalaise de Cancérologie" (SOSECAN)

Journal homepage: www.africanjournalofoncology.com

Original article / Article original

DOI: https://www.doi.org/I0.54266/ajo.I.2.55.WMWE85I5

\title{
Profile of parotid cancers at the ENT clinic Lamine Sine Diop of Fann teaching hospital
}

\section{Profil des cancers de la parotide à la clinique ORL Lamine Sine Diop du CHU de Fann}

\author{
A. Dièye ${ }^{\prime *}$, H. Younés', C. Ndiaye', H. Ahmed', L. Yassine', B. Loum², M. Ndiaye ${ }^{3}$, IC. Ndiaye'.
}

I Clinique ORL Lamine Sine Diop, CHU de Fann, Sénégal.

2 Service d'ORL, Hôpital d'Enfants Albert Royer, Sénégal.

${ }^{3}$ Service d'ORL, Hôpital pour enfants de Diamniadio, Sénégal.

INTRODUCTION: Parotid cancers are characterized by a great histological diversity and they pose diagnostic, therapeutic and evolutionary problems. We deliver through this study our experience on the management of malignant parotid tumors. MATERIALS AND METHODS: This is a retrospective, descriptive and analytical study carried out over a period of 12 years in the ENT department of Fann teaching hospital. RESULTS: The mean age at diagnosis was 48 years with a sex-ratio of I.6. The time to symptom progression was approximately 47 months. Parotid swelling was present in all patients and peripheral facial palsy was found in $31 \%$ of patients. Ultrasound of the parotid region was performed in II patients, i.e. $34 \%$, and computed tomography in 18 patients, i.e. $56 \%$. Fine needle aspiration was performed in II patients. Parotid cancers accounted for $44 \%$ of all parotid tumors. Sixty-eight percent of patients consulted at the T4 stage. Seventy-one percent of patients received surgical treatment. The most common histologic type was muco-epidermoid carcinoma. Five patients received radiotherapy. The postoperative effects were dominated by PFP (18\%). Seven cases of death were recorded. CONCLUSION: The management of parotid cancer still poses diagnostic and above all therapeutic problems. The combination of radiotherapy surgery, very rarely encountered in our study, provides a better prognosis and better survival.

KEYWORDS: Parotid; Cancer; Parotidectomies; Radiotherapy.

INTRODUCTION : Les cancers de la parotide sont caractérisés par une grande diversité histologique et ils posent des problèmes diagnostiques, thérapeutiques et évolutifs. Nous livrons à travers cette étude notre expérience sur la prise en charge des tumeurs malignes de la parotide. MATERIELS ET METHODES : Il s'agit d'une étude rétrospective, descriptive et analytique réalisée sur une période de 12 ans dans le service d'ORL du CHNU de Fann. RESULTATS : L'âge moyen au moment du diagnostic était de 48 ans avec un sex-ratio de I,6. La durée d'évolution des symptômes était d'environ de 47 mois. La tuméfaction parotidienne était présente chez tous les patients et une paralysie faciale périphérique était retrouvée chez $31 \%$ des patients. L'échographie de la région parotidienne a été réalisée chez II patients, soit 34\% et la tomodensitométrie chez 18 patients, soit $56 \%$. La cytoponction était effectuée chez II patients. Les cancers parotidiens représentaient $44 \%$ de l'ensemble des tumeurs parotidiennes. Soixantehuit pour cent des patients ont consulté au stade de T4. Soixante-onze pourcent des patients ont bénéficié d'un traitement chirurgical. Le type histologique le plus fréquent était le carcinome muco-épidermoïde. Cinq patients ont bénéficié de radiothérapie. Les suites opératoires ont été dominées par la PFP (18\%). Sept cas de décès ont été enregistrés. CONCLUSION : Le profil des cancers de la parotide est caractérisé par l'âge jeune, le stade avancé au diagnostic et l'absence de traitement adapté caractérisé en dehors de la chirurgie par la rareté de la radiothérapie et de la chimiothérapie.

MOTS-CLES : Parotide ; Cancer ; Parotidectomies ; Radiothérapie.

\section{INTRODUCTION}

Les cancers de la parotide représentent $20 \%$ des tumeurs parotidiennes [ 1,2$]$. Les cancers parotidiens sont caractérisés par leur grande diversité de présentation clinique, histologique, d'évolution et de pronostic [3]. Le type histologique le plus fréquent est le carcinome muco-épidermoïde.

Le but de notre travail rétrospectif était d'étudier les aspects épidémiologiques, la présentation clinique des cancers parotidiens, leurs aspects histologiques thérapeutiques et évolutifs et de définir les facteurs pronostiques au sein de la clinique d'ORL et de chirurgie cervico-faciale du CHU de Fann.

\section{MATERIELS ET METHODES}

II s'agit d'une étude rétrospective, descriptive et analytique réalisée sur une période de 10 ans (premier Octobre 2009 au 3I Décembre 2019) dans le service d'ORL du CHNU de Fann. Nous avons inclus dans notre étude tout patient ayant consulté pour cancer de la parotide opéré et non opéré histologiquement documenté. Les paramètres étudiés étaient épidémiologiques, cliniques, paracliniques, histologiques, thérapeutiques et évolutifs. L'analyse des données a été faite par le logiciel Microsoft ExcelC 2010.

\section{RESULTATS}

Sur un total de 63 patients présentant une tumeur de la parotide, 32 souffraient de cancers soit $50 \%$. 
Données sociodémographiques

L'âge moyen était de 48 ans avec des extrêmes allant de II à 89 ans avec un pic entre 40 et 60 ans (Figure I).

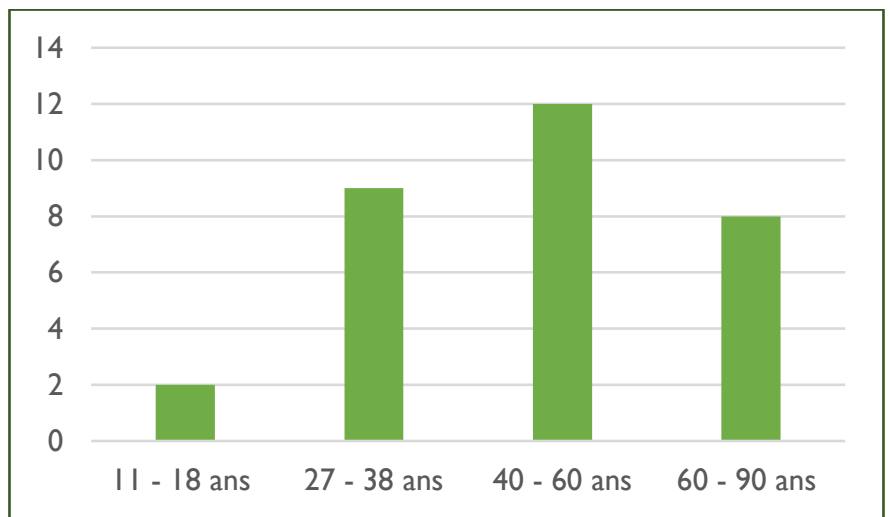

Figure I : Répartition selon l'âge.

Le sex-ratio était de I,6 avec une prédominance masculine (20 hommes sur 12 femmes). Le délai médian de consultation était de 47 mois avec des extrêmes allant de 4 mois à 30 ans.

\section{Données cliniques}

Tous nos patients ont présenté une tuméfaction de la région parotidienne au moment de la consultation (Figure 2).

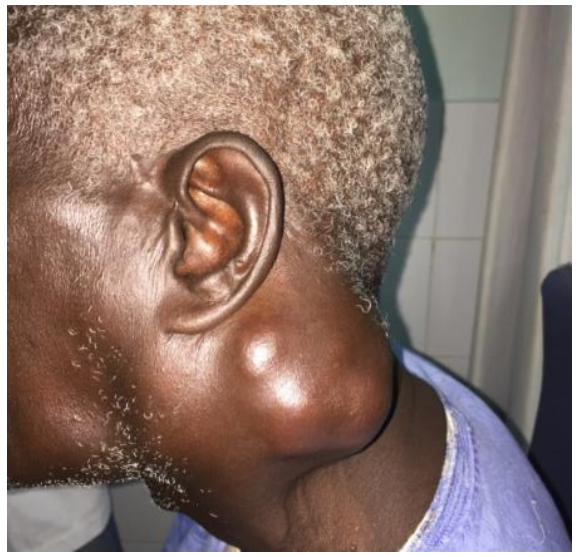

Figure 2 : Tuméfaction parotidienne rétro-angulomaxillaire gauche.

La taille moyenne de la masse parotidienne était de huit $\mathrm{cm}$ avec des extrêmes de trois à $20 \mathrm{~cm}$. Le siège de la tuméfaction était sous lobulaire dans 17 cas (53\%). Elle était dure dans 19 cas $(59 \%)$, ferme dans II cas $(34 \%)$ et fixée dans six cas. Elle était associée à des douleurs locales dans neuf cas (28\%), à une paralysie faciale périphérique dans 10 cas (31\%), à des adénopathies suspectes dans huit cas (25\%). Une atteinte cutanée était retrouvée dans 14 cas (43\%) faite de lésion ulcéro-bourgeonnante ou de fistulisation. Nous notions également un trismus dans deux cas (Figure 3).

\section{Données paracliniques}

L'échographie a été effectuée dans II cas, soit 34\%, montrant dans tous les cas une formation tissulaire hétérogène suspecte. La tomodensitométrie (TDM) réalisée dans 18 cas, soit $56 \%$, montrait une tumeur isolée de la parotide dans trois cas, une tumeur avec extension locorégionale dans 15 cas, soit $46 \%$ et des métastases pulmonaires dans quatre cas (Figure 4).

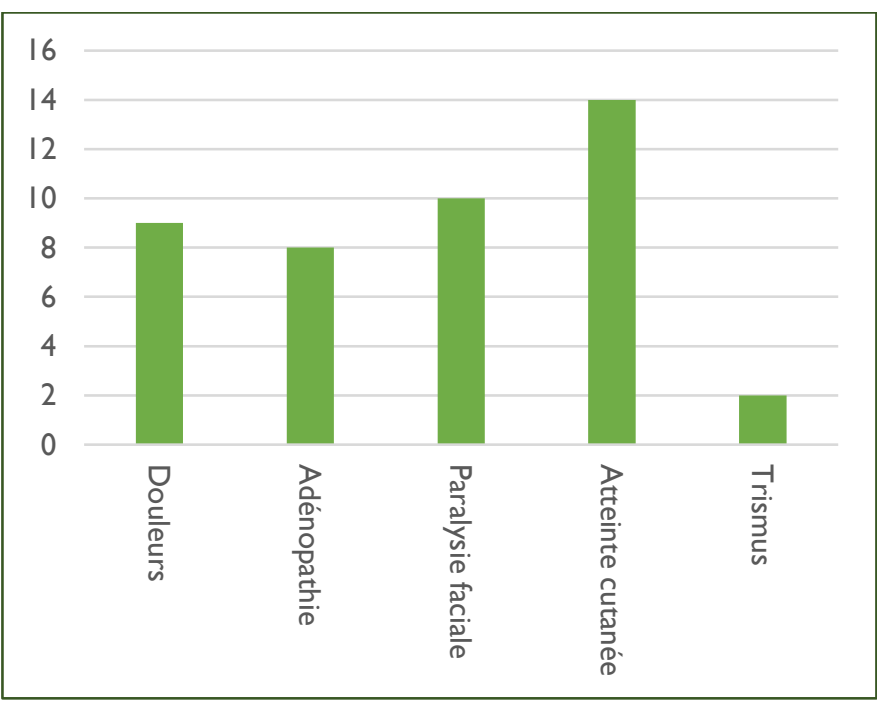

Figure 3 : Signes cliniques associés.

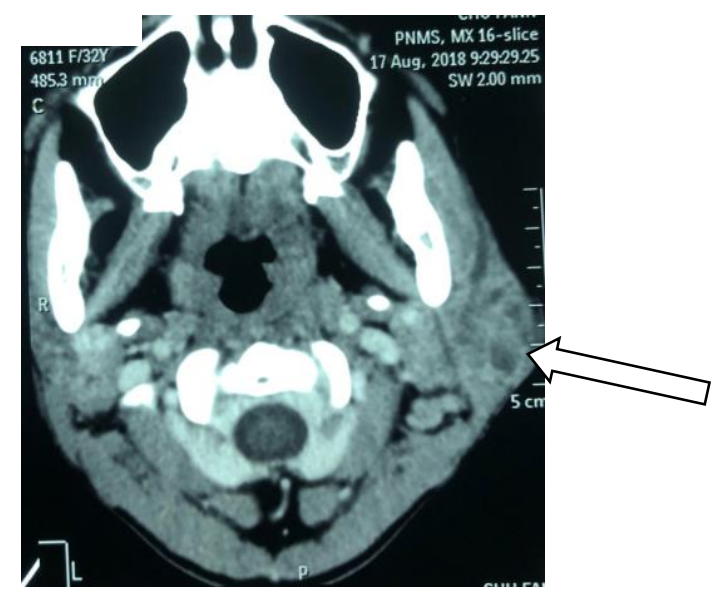

Figure 4: TDM en coupe axiale correspondant à un carcinome muco-épidermoïde de la parotide droite (flèche blanche) [Source : Collection ORL Fann]

L'imagerie par résonance magnétique (IRM) a été faite dans deux cas, soit $8 \%$ et elle objectivait une lésion étendue au lobe temporal gauche ou à la fosse infra-temporale. La cytoponction a été pratiquée dans II cas, soit $34 \%$. Elle montrait une lésion suspecte de malignité dans trois cas, soit $9 \%$, une lésion maligne dans un cas, une lésion bénigne dans six cas, soit $18 \%$, elle était non contributive dans un cas. Son association avec l'IRM a été effectuée dans un cas et la cytoponction montrait une lésion bénigne avec des atypies modérées, il s'agissait en effet d'un cylindrôme. Soixante-huit pour cent des patients ont consulté au stade de T4 (2I cas), dans quatre cas, la lésion était classée T2, dans trois cas, elle était classée T3. Quatre patients ont présenté des métastases.

\section{Données thérapeutiques}

Sur le plan chirurgical, 10 patients, soit $27 \%$ ont bénéficié d'une parotidectomie totale non conservatrice (PTNC) et neuf patients, soit $28 \%$ ont bénéficié d'une parotidectomie totale conservatrice (PTC), quatre patients ont bénéficié d'une parotidectomie totale élargie (PTE). Un curage ganglionnaire a été réalisé dans neuf cas, soit $28 \%$. II s'agissait d'un curage fonctionnel dans cinq cas, d'un curage radical dans deux cas et d'un curage triangulaire dans deux cas. La reconstruction des pertes de substances cutanées a été faite à l'aide de lambeaux 
pédiculés myo-cutané du grand pectoral ou temporo-frontal dans quatre cas (Figure 5).

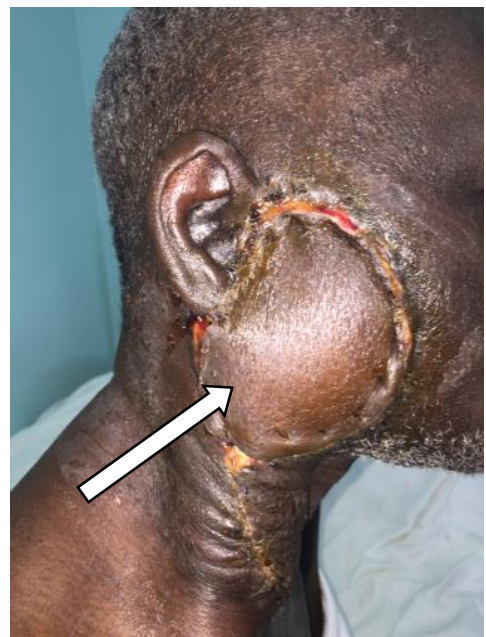

Figure 5 : LMCGP (flèche blanche) après PTNC droite pour carcinome mucoépidermoïde de haut grade étendu au CAE.

La radiothérapie a été effectuée dans six cas, soit $18 \%$. Sept patients ont bénéficié d'une chimiothérapie, parmi eux, quatre présentaient des lésions inopérables.

\section{Données pathologiques}

L'analyse anatomo-pathologique des pièces opératoires ou des biopsies avait révélé une grande diversité histo-pathologique (Tableau I).

Tableau I : Répartition histologique.

\begin{tabular}{|lll|}
\hline Type histologique & Effectif & Pourcentage (\%) \\
\hline $\begin{array}{l}\text { Carcinome muco- } \\
\text { épidermoïde }\end{array}$ & 9 & 28 \\
$\begin{array}{l}\text { Carcinome } \\
\text { épidermoïde }\end{array}$ & 6 & 18 \\
$\begin{array}{l}\text { Carcinome adénoïde } \\
\text { kystique }\end{array}$ & 5 & 15 \\
\begin{tabular}{l} 
Adénocarcinome \\
\hline
\end{tabular} & 4 & 12 \\
\hline
\end{tabular}

\section{Evolution}

Les suites précoces étaient une paralysie faciale périphérique dans six cas, une infection du site opératoire (ISO) dans quatre cas, une nécrose et une infection du lambeau dans trois cas, une parésie dans trois cas, un hématome, ISO et une nécrose dans un cas et une nécrose du site opératoire dans un cas. Les suites tardives étaient un syndrome de Frey dans deux cas, une poursuite évolutive dans quatre cas (à un mois, quatre mois, sept mois et huit mois) et une radiodermite dans un cas. Quatorze patients, soit $43 \%$ ont été perdus de vue et sept cas de décès ont été déplorés. Les suites ont été simples pour six patients. Le recul moyen était de 20 mois.

\section{DISCUSSION}

Les cancers de la parotide représentent 20 à $40 \%$ des tumeurs de la parotide, ce chiffre est légèrement inférieur à celui retrouvé dans notre série qui est de $50 \%$. L'âge moyen constaté de 48 ans est retrouvé par plusieurs auteurs $[4,5]$. La prédominance masculine notée dans plusieurs travaux est également caractéristique des cancers de la parotide $[6,7]$. Les longs délais de consultation dans notre contexte sont liés aux difficultés d'accès aux soins ORL dans certaines localités, à la négligence mais aussi à la peur de la chirurgie. Ces longs délais font découvrir des formes géantes de tumeur parotidienne, mais aussi des lésions très évoluées non éligibles à une chirurgie carcinologique [4]. La malignité des tumeurs parotidiennes est suspectée en présence de douleur, de paralysie faciale, d'atteinte ganglionnaire, d'atteinte cutanée ou de trismus [4, 8-II]. Pour certains auteurs, la douleur est associée aux tumeurs malignes dans $25 \%$, ce qui corrobore nos résultats [12]. La présence de parésie ou de paralysie faciale est estimée entre 12 et $20 \%$ [10]. Ce chiffre est inférieur à celui retrouvé dans notre étude donnant à l'atteinte nerveuse un véritable facteur prédictif de cancer. Le risque de PFP dépend de certains facteurs à savoir l'âge avancé, le type et le grade histologiques, le délai de chirurgie, l'extension tumorale, une chirurgie secondaire ou de récidive [13]. L'atteinte ganglionnaire évaluée entre 10 à $20 \%$ est également reconnue comme étant un facteur de récidive et de métastases surtout pulmonaires.

Sur le plan radiologique, l'échographie est l'examen de base, non invasif, de réalisation simple et rapide [14]. Certains signes échographiques tels que le caractère hétérogène, mal limité et à contours irréguliers de la tumeur ainsi qu'une vascularisation intense peut être suspects de malignité [14]. La TDM est devenue un examen de plus en plus utilisée dans nos conditions d'exercice [56\%], contrairement il y a une quinzaine d'années où elle était de $13 \%$ [4]. Elle permet de préciser la topographie des lésions et leurs extensions aux structures adjacentes surtout osseuses. L'IRM réalisée dans trois cas, soit $8 \%$ pose toujours un problème d'accessibilité dans notre pratique du fait de son cout élevé et de sa disponibilité. L'IRM apparait actuellement comme l'examen préférentiel dans l'exploration de la pathologie tumorale de la glande parotide [16]. L'infiltration des espaces péri-glandulaires fait évoquer une tumeur maligne, de même que la présence d'adénopathies nécrotiques et d'une capsule glandulaire mal limitée et irrégulière, elle permet aussi la discrimination bénigne-maligne dans $80 \%$ des cas, possible grâce au coefficient d'ADC (coefficient apparent de diffusion) dont des valeurs basses sont en faveur d'une lésion maligne [16, 17]. Cette différenciation est de $92 \%$ lorsqu'elle est couplée à la cytoponction échoguidée [17].

Dans notre contexte, la cytoponction ne permet pas d'éviter la chirurgie radicale mais permet de planifier le traitement des aires ganglionnaires, mais aussi de donner une meilleure information au patient. Le taux de faux négatif est de $31 \%$ dans la littérature, du fait de la grande diversité histologique des tumeurs parotidiennes rendant l'examen cytologique difficile [18]. Longuet et al [18] retrouvait une sensibilité et une spécificité de $81 \%$ et $97,5 \%$ respectivement, taux similaire avec ceux de Lim et al [19] avec $80 \%$ de sensibilité et de $100 \%$ de spécificité. Son association avec l'IRM permettent de planifier le geste opératoire (parotidectomie exofaciale ou totale et évidement cervical), mais ne guident pas l'attitude sur le nerf facial [9]. Cette association a été effectuée dans un seul cas dans notre étude et il s'agissait d'un cylindrôme. Le manque de moyens, l'inaccessibilité à l'IRM et les faux négatifs de la cytoponction font que cette association tarde à être régulièrement utilisée couramment dans nos structures. 
Les tumeurs malignes représentent $20 \%$ des tumeurs parotidiennes [6], nos résultats montraient $50 \%$ de tumeurs malignes. Le carcinome muco-épidermoïde est habituellement le plus fréquent [20] (Tableau II). Erovic et al [5] avait retrouvé un taux de $32 \%$, chiffre similaire à celui retrouvé dans notre étude avec $28 \%$.

\begin{tabular}{|c|c|}
\hline Auteurs & Types histologiques \\
\hline $\begin{array}{l}\text { Lierop et al } \\
\text { (Afrique du Sud, } \\
\text { 2007) [3] }\end{array}$ & $\begin{array}{l}\text { Carcinome épidermoide } \\
\text { Carcinome muco-épidermoide } \\
\text { Mélanome }\end{array}$ \\
\hline $\begin{array}{l}\text { Lee et al (Brésil, } \\
2018 \text { ) [27] }\end{array}$ & $\begin{array}{l}\text { Carcinome canalaire } \\
\text { Carcinome muco-épidermoide } \\
\text { Carcinome épidermoide }\end{array}$ \\
\hline $\begin{array}{l}\text { Paris et al } \\
\text { (France, 2004) } \\
\text { [22] }\end{array}$ & $\begin{array}{l}\text { Carcinome muco-épidermoide } \\
\text { Carcinome adénoïde kystique } \\
\text { Carcinome ex adénome pléomorphe }\end{array}$ \\
\hline $\begin{array}{l}\text { Beltaief (Tunisie, } \\
\text { 2007) [8] }\end{array}$ & $\begin{array}{l}\text { Carcinome sur tumeur mixte } \\
\text { Carcinome muco-épidermoide } \\
\text { Maladie de Hodgkin }\end{array}$ \\
\hline $\begin{array}{l}\text { Venkatesh (Inde, } \\
\text { 2019) [2I] }\end{array}$ & $\begin{array}{l}\text { Carcinome muco-épidermoide } \\
\text { Carcinome ex adénome pléomorphe } \\
\text { Adénocarcinome }\end{array}$ \\
\hline $\begin{array}{l}\text { Notre étude } \\
\text { (Sénégal, 2020) }\end{array}$ & $\begin{array}{l}\text { Carcinome muco-épidermoide } \\
\text { Carcinome épidermoide } \\
\text { CAK / Adénocarcinome }\end{array}$ \\
\hline
\end{tabular}

Les lésions classées T3-T4 prédominent dans nos études comme l'illustre ce travail où $64 \%$ des patients ont consulté au stade de T4 et trois patients au stade de T3. Ces résultats s'opposent à ceux de Paris et al [22] où $74 \%$ des patients étaient classés TI-T2 avec $86 \%$ de patients classés N0. Ces formes avancées rencontrées dans notre étude expliquent le recours aux lambeaux de reconstruction et la fréquence des poursuites évolutives responsables d'une lourde mortalité.

Devant toute tumeur maligne de la parotide, la parotidectomie totale est la règle associée ou non à un curage ganglionnaire et/ou à une radiothérapie [6]. Et l'enjeu chirurgical sera une chirurgie carcinologique avec de bonnes marges de sécurité et la préservation du nerf facial dans la mesure du possible. La PTNC est systématique dans notre pratique, devant toute PFP en préopératoire, de même que lorsqu'il existe une extension au nerf facial découverte en peropératoire. Cette attitude maximaliste est liée à l'absence d'examen extemporané et de monitoring du nerf facial, mais aussi à la difficulté de payer une seconde intervention [4, 23]. Le curage est systématique en cas d'adénopathies palpables pour les tumeurs T2-T4 de haut grade de malignité, pour les TI, un curage sélectif est fait et sera complété si positif à l'examen extemporané par un curage fonctionnel [24]. L'évidemment ganglionnaire est discuté pour les tumeurs de bas grade [II]. L'examen extemporané peut guider l'attitude sur les ganglions en fonction de la fréquence des adénopathies selon le type histologique. La difficulté d'accès à l'examen extemporané au Sénégal ne permet pas de réaliser un curage sélectif devant un cas avéré de cancer parotidien, justifiant l'attitude maximaliste à réaliser une PTC avec curage fonctionnel devant tout cas de tumeur suspecte de malignité de la glande parotide. La majorité des adénopathies
(66\%) dans cette présente étude étaient retrouvées dans les carcinomes épidermoïdes, dans $22 \%$, il s'agissait d'adénocarcinome et de carcinome muco-épidermoïde dans $22 \%$. La discussion d'une parotidectomie ne se fait pas sans parler du nerf facial. La parotidectomie peut être élargie au nerf facial en cas d'atteinte de celui-ci. L'attitude vis-à-vis du nerf facial n'est pas codifiée. Certains auteurs craignant de léser le nerf facial, le conservent même s'il est macroscopiquement envahi et complètent par une radiothérapie [9]. Cependant l'objectif d'une chirurgie pour cancer de la parotide est d'être carcinologique [10]. Dans notre série, ce sacrifice a été réalisé dans 10 cas, soit $27 \%$, illustrant l'importance des lésions étendues au nerf facial. Concernant le traitement complémentaire, plusieurs études confirment l'amélioration du pronostic et du taux de survie en cas d'association chirurgieradiothérapie par augmentation du taux de contrôle locorégional de 57 à $83 \%$ en cas de $\mathrm{NI}[5,8,9,25,26]$. Pour les patients N0, le traitement des aires ganglionnaires fait toujours l'objet de débat. Les facteurs prédictifs d'extension ganglionnaire empiriques restent le type histologique, le grade histologique, la taille de la tumeur [9]. Dans notre étude, plusieurs protocoles de fin d'irradiation n'ont pas été retrouvés rendant difficile la comparaison avec d'autres études. Les indications actuellement admises par la plupart des auteurs $[3,9,17]$ sont des limites d'exérèse chirurgicales envahies, une invasion lymphatique, vasculaire et péri-neurale, des tumeurs de haut grade de malignité, une extension tumorale extraglandulaire, des adénopathies envahies et une extension au lobe profond.

Concernant les complications, la PFP était objectivée dans $24 \%$ des cas. Un taux similaire (30\%) était retrouvé dans l'étude de Lee et al [27], ce chiffre est proche de l'incidence globale de la parésie dans la littérature [28]. Le syndrome de Frey a été retrouvé dans $5 \%$ dans cette série. Le taux de récidive était faible (un patient). Il était de $22 \%$ dans l'étude de Erovic et al [5]. Cette différence peut s'expliquer par le faible taux de radiothérapie post-opératoire (18\%). Les facteurs pronostiques péjoratifs évoqués par plusieurs auteurs sont la taille de la lésion (supérieure à quatre $\mathrm{cm}$ ), la présence d'adénopathies cervicales, l'atteinte du nerf facial, le type histologique, le grade histologique élevé, des marges d'exérèse insuffisantes, une invasion lymphatique et péri neurale et l'âge supérieur à 55 ans [3, 5]. La survie est de 70 à $100 \%$ à cinq ans pour les carcinomes muco-épidermoïdes de bas grade et de zéro à $50 \%$ à cinq ans pour les carcinomes muco-épidermoïdes de haut grade, les cylindrômes et les épidermoïdes [7]. Dans cette série, $40 \%$ des carcinomes muco-épidermoïdes étaient de haut grade.

\section{CONCLUSION}

Les cancers de la parotide sont relativement rares, ils sont caractérisés par une grande diversité histologique et ils posent des problèmes diagnostiques, thérapeutiques et évolutifs. L'imagerie est d'un apport indéniable dans le diagnostic. La cytoponction peu réalisée dans notre étude, constitue un élément utile dans l'orientation diagnostique et la décision thérapeutique lorsqu'elle est couplée à l'IRM. Les longs délais de consultation expliquent la fréquence des stades avancés et l'attitude maximaliste dans notre pratique. Le développement de l'examen extemporané permettrait de limiter les gestes excessifs. La chirurgie carcinologique suivie d'une radiothérapie permet d'assurer un meilleur contrôle 
locorégional de la tumeur et une survie meilleure. Ce traitement n'est pas toujours disponible chez nos patients.

\section{CONFLITS D'INTERET}

Les auteurs n'ont déclaré aucun conflit d'intérêts.

\section{REFERENCES}

I. Diom E-S, Thiam A, Tall A, Ndiaye M, Toure S, Diouf R. Profil des tumeurs de la glande parotide: expérience sur 93 cas colligés en I6ans. Ann Fr OtoRhino-Laryngol Pathol Cervico-Faciale. févr 2015; I32(1):9-12.

2. Golar R, C. Anatomie chirurgicale de la région parotidienne. 95(6):395 - 4I0.

3. Lierop ACV, Fagan JJ. Parotidectomy in Cape Town a review of pathology and management. SAJS. 2007. 45;3. 96-103.

4. Diom Es, Déguenonvo Rea, Tall A, Ndiaye M, Diop A. Aspects chirurgicaux des cancers parotidiens au SénégaL: A propos de 30 cas. RevCAMES-Sér A. 20I2; I3((I)):63-5.

5. Erovic BM, Shah MD, Bruch G, Johnston M, Kim J, O'Sullivan B, et al. Outcome analysis of 215 patients with parotid gland tumors: a retrospective cohort analysis. J Otolaryngol - Head Neck Surg. déc 2015;44(I):43.

6. Bouaity B, Darouassi* $Y$, Chihani M, Touati MM, Ammar $\mathrm{H}$. Les facteurs prédictifs de malignité dans la prise en charge des tumeurs parotidiennes: à propos de 76 cas. Pan Afr Med J 2016. 23; II 2.

7. Vincentiis MD, Magliulo G, Soldo P, Manciocco V, Pagliuca G, Gaizo RD et al. Extended parotidectomy. Acta Otorhinolaryngol Ital 2005. 25, 169-I73,

8. Beltaief N, Tababi S, Atallah S, Mansour M, Ouertatani I, Charfi A, et al. Les Tumeurs Malignes De La Parotide. J Tunis ORL Chir Cervico-Faciale. 25 août 2008; | (1):25-8.

9. Bouyon A, Hans S, Durdux C, Housset M. Tumeurs malignes de la parotide: prise en charge multidisciplinaire, rôle de la radiothérapie. Cancer/Radiothérapie. déc 2007; I I (8):465-75.

10. Cracchiolo JR, Shaha AR. Parotidectomy for Parotid Cancer. Otolaryngol Clin North Am. avr 2016;49(2):4I5-24.

I I. Spiro RH. Management of malignant tumours of the salivary glands. Oncology. 1998;(I2):67I-83.

12. Prades J-M, Oletski A, Faye M-B, Dumollard J-M, Timoshenko A-P, Veyret $C$, et al. Morphologie IRM des tuméfactions de la glande parotide. Corrélations histopathologiques. Morphologie. mars 2007;9I (292):44-5 I.

13. Ikoma R, Ishitoya J, Sakuma Y, Hirama M, Shiono O, Komatsu $M$, et al. Temporary facial nerve dysfunction after parotidectomy correlates with tumor location. Auris Nasus Larynx. oct 20I4;4I(5):479-84.

14. Bruneton J, Mourou M. Ultrasound in salivary gland disease. ORL. 1993;(55):284-9.

15. Makeieff M, Guerrier B, Prades J-M, Reyt E, Zanaret M. Pathologie maligne de la parotide. Ann Otolaryngol Chir Cervico-Faciale. avr 2009; I 26(2):75-8I.
16. Raine C, Saliba K, Chippindale A J, et al. Radiological imaging in primary parotid malignancy. British Journal of Plastic Surgery 2003; 56:637-643.

17. Maruo T, Fujimoto Y, Yoshida K, Hiramatsu M, Suzuki A, Nishio $\mathrm{N}$, et al. Effect of clinical symptoms on the indication for selective neck dissection for NO carcinomas of the parotid gland. Oncol Lett. juill 2014;8(I):335-8.

18. Longuet M, Nallet E, Guedon C, Depondt J. Valeur diagnostique de la cytoponction et de l'examen histologique extemporané dans les tumeurs parotidiennes primitives opérées. Rev Laryngol Otol Rhinol. 200I; I (I22):5 I-5.

19. Lim CM, They J, Loh KS, Chao SS, Lim LHY, Tan LKS. Role of fine-needle aspiration cytology in the evaluation of parotid tumours. ANZ J Surg. sept 2007;77(9):742-4.

20. Sood S, McGurk M, Vaz F. Management of Salivary Gland Tumours: United Kingdom National Multidisciplinary Guidelines. J Laryngol Otol. mai 2016;130(S2):SI42-9.

21. Venkatesh S, Srinivas T, Hariprasad S. Parotid gland tumors: 2-year prospective clinicopathological study. Ann Maxillofac Surg. 2019;9(I):103.

22. Paris J, Coulet O, Facon F, Chrestian M-A, Giovanni A, Zanaret $M$. Cancers primitifs de la parotide: approche anatomo-clinique. Rev Stomatol Chir Maxillofac. déc 2004; I05(6):309-I5.

23. Diop E, Hitimana A, Diouf R, Diop LS. Bilan de 40 parotidectomies. Rev Laryngol Otol Rhinol. 1984;(105):25-31.

24. Harish K. Management of primary malignant epithelial parotid tumors. Surg Oncol. juill 2004;13(1):7-16.

25. Kaur J, Goyal S, Muzumder S, Bhasker S, Mohanti BK, Rath GK. Outcome of Surgery and Post-Operative Radiotherapy for Major Salivary Gland Carcinoma: Ten Year Experience from a Single Institute. Asian Pac J Cancer Prev. 23 oct 2014; I5(19):8259-63.

26. Terhaard $\mathrm{CHJ}$, Lubsen $\mathrm{H}$, Rasch $\mathrm{CRN}$, Levendag PC, Kaanders HHÀM, Tjho-Heslinga RE, et al. The role of radiotherapy in the treatment of malignant salivary gland tumors. Int J Radiat Oncol. janv 2005;6I(I):I03-II.

27. Lee DH, Yoon TM, Lee JK, Lim SC. Clinicopathologic factors associated with recurrence in parotid carcinoma. Braz J Otorhinolaryngol. nov 20I8;84(6):69I-6.

28. Jin H, Kim BY, Kim H, Lee E, Park W, Choi S, et al. Incidence of postoperative facial weakness in parotid tumor surgery: a tumor subsite analysis of 794 parotidectomies. BMC Surg. déc 2019;19(I):199. 
An official journal of the / Un journal officiel de la "Société Sénégalaise de Cancérologie" (SOSECAN)

Journal homepage: www.africanjournalofoncology.com

DOI: https://www.doi.org/I0.54266/ajo.1.2.60.JFIC48I3

\title{
Undifferentiated carcinoma of the nasopharynx associated with an early paraneoplastic dermatomyositis TINOMO: About a one case
}

\section{Carcinome indifférencié du nasopharynx associé à une dermatomyosite paranéoplasique à un stade précoce TINOMO : A propos d'un cas et revue de la littérature}

S. Panandtigri'*, M. Charkaoui', NPX. Sia', N. Benchakroun', C. Tarek', M. Bourhafour', Z. Bouchbika', H. Jouhadi', N. Tawfiq', S. Saharaoui', A. Benider'.

I Centre Mohamed VI pour le traitement des cancers du Centre Hospitalier Universitaire lbn Rochd de Casablanca, Maroc.

\begin{abstract}
Dermatomyositis (DM) is a rare autoimmune disease characterized by non-infectious inflammatory damage to the skin and the predominant muscles in the belts. It is believed to be associated with about one case per I,000 nasopharyngeal carcinoma (NPC). This association has been described for the locally advanced stage, stage II and stage III of the NPC. Little described in the early stages (stage I), its symptomatology is often indicative of cancer whose diagnosis is based on five criteria: muscle weakness of the proximal limbs, elevation of serum muscle enzymes, histological muscle abnormalities in muscle biopsy, electromyographic abnormality and clinical inflammatory dermatological manifestation. Treatment is based on corticosteroid therapy and etiological treatment of cancer. The prognosis of NPC in patients with paraneoplastic DM is comparable to noninfected patients. We report this case of DM revealing an early stage NPC and we take stock of the state of knowledge about paraneoplastic DM associated with rarely described NPC. Indeed, in Morocco the last description of a case dates back to 2016.
\end{abstract} KEYWORDS: Dermatomyositis; Paraneoplastic; Nasopharynx; Corticosteroid therapy; Radiotherapy.

RESUME : La dermatomyosite (DM) est une maladie auto-immune rare, caractérisée par une atteinte inflammatoire non infectieuse de la peau et des muscles prédominants aux ceintures. Elle serait associée à environ un cas sur 1.000 au carcinome nasopharyngé (NPC). Cette association a été décrite pour les stades localement avancés, stade II et stade III du NPC. Peu décrite à des stades précoces (stade I), sa symptomatologie est souvent révélatrice du cancer dont le diagnostic repose sur cinq critères : la faiblesse musculaire des membres proximaux, l'élévation des enzymes musculaires sériques, les anomalies musculaires histologiques à la biopsie musculaire, l'anomalie électromyographique et la manifestation dermatologique inflammatoire clinique. Le traitement repose sur la corticothérapie et le traitement étiologique du cancer. Le pronostic des NPC chez les patients atteints de DM paranéoplasique est comparable aux patients non atteints. Nous rapportons ce cas de DM révélant un NPC à un stade précoce et nous faisons le point sur l'état des connaissances sur la DM paranéoplasique associée à un NPC rarement décrite. En effet, au Maroc la dernière description d'un cas remonte en 2016.

MOTS-CLES : Dermatomyosite ; Paranéoplasie ; Nasopharynx ; Corticothérapie ; Radiothérapie.

\section{INTRODUCTION}

La dermatomyosite (DM) est une maladie auto-immune rare, caractérisée par une atteinte inflammatoire non infectieuse de la peau et des muscles prédominants aux ceintures [ $\mathrm{I}$ ]. Elle est associée à une tumeur maligne dans 18 à $32 \%$ des cas, apparaissant avant, simultanément ou après le diagnostic du cancer [2]. Ces cancers sont notamment des cancers ovariens, bronchiques, du sein, de la région de la tête et du cou ou plus rarement des lymphomes.

En effet, l'incidence de DM associée à un carcinome pharyngé (NPC) est de l'ordre d'un pour 1.000 cas de NPC [3]. Cette association a été décrite pour les stades localement avancés, stade II [3] et stade III [4] du NPC. L'objectif de la présente étude est de rapporter un cas de DM paranéoplasique révélant un carcinome indifférencié du nasopharynx (UCNT) à un stade précoce (stade I). Nous décrirons par ailleurs les aspects diagnostics, thérapeutiques et pronostiques de cette entité, bien que rare, qui pourrait aider les cliniciens à un diagnostic précoce de ces cancers.

\section{OBSERVATION}

II s'agit d'un patient de 65 ans, sans antécédents particuliers référé au Centre Mohamed VI pour le traitement des cancers du Centre Hospitalier Universitaire ( $\mathrm{CHU}$ ) Ibn Rochd de Casablanca, pour prise en charge d'un cancer du nasopharynx. Le début de sa symptomatologie remonte à trois mois par l'apparition d'une dysphagie au solide intermittente, puis devenue totale, motivant la mise en place d'une sonde nasogastrique d'alimentation, associée à une éruption cutanée au visage et aux mains avec une fatigue intense et un amaigrissement important non chiffré. A l'examen clinique, nous retrouvions un patient très altéré avec un Performans Status (PS) à trois, un érythème au niveau du visage, du cou et des extrémités avec un score CDASI (Cutanéous Dermatomyositus Disease Area and Severity Index) à 15 (Figures I, 2 et 3). L'examen révélait aussi un déficit musculaire au niveau des muscles axiaux coté à huit selon le MMT (Manual Muscle Testing) ; les muscles proximaux à 32 et distaux à huit avec un score global MMT à 48 sur 260 [I]. 


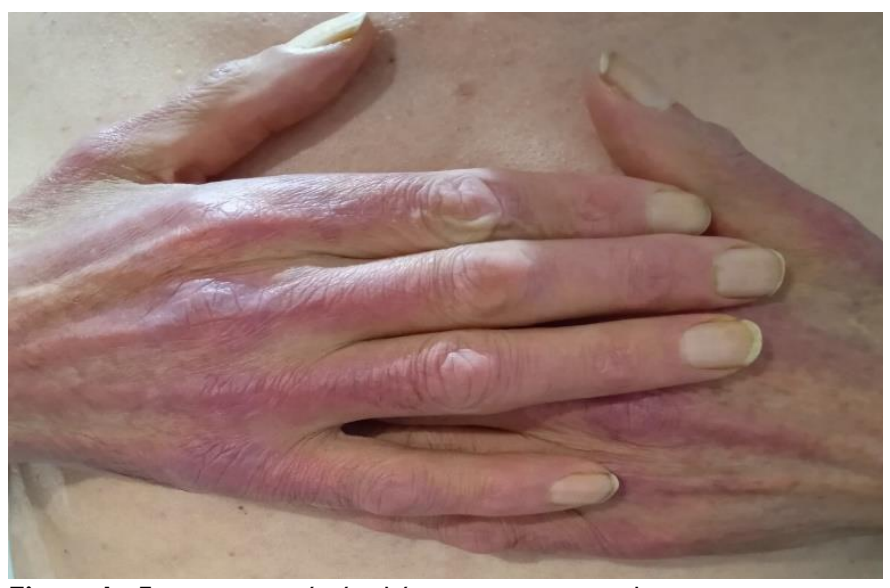

Figure I : Eruption cutanée érythémateuse au niveau des mains.

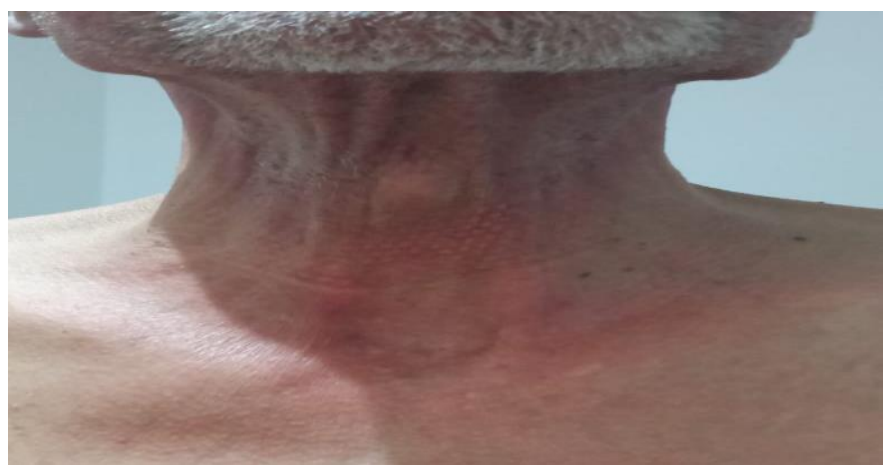

Figure 2 : Eruption cutanée érythémateuse au niveau de la face antérieure du cou.

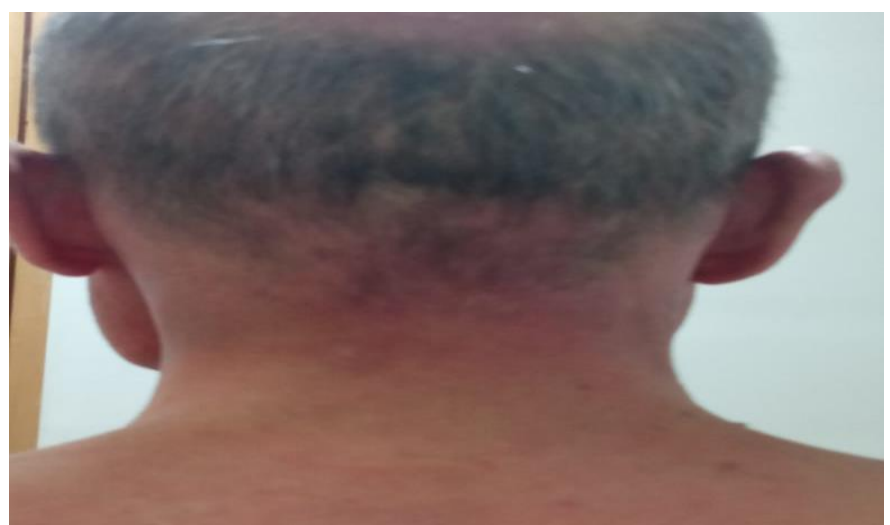

Figure 3 : Eruption cutanée érythémateuse au niveau de la face postérieure du cou.

Le bilan para-clinique pour le diagnostic du cancer était fait de panendoscopie montrant un processus tumoral au niveau de la paroi postérieure du nasopharynx et la biopsie retrouvait un UCNT, confirmé à l'immunohistochimie par expression de P63. Un bilan radiologique fait d'imagerie par résonnance magnétique (IRM) du nasopharynx et d'une tomographie par émission de positon (TEP) a permis de poser le diagnostic de UCNT du nasopharynx stade I (TINOM0). Devant les signes cliniques évocateurs de DM, un bilan biologique demandé avait montré l'élévation du lactate déshydrogénase (LDH) : 30 I $\mathrm{UI} / \mathrm{L}$; avec créatine phosphokinnase (CPK): $148 \mathrm{UI} / \mathrm{L}$ (normale) et les anticorps anti-nucléaires positifs à I/640 de types homogènes.

Le diagnostic final de DM paranéoplasique avec un IMACS (évaluation globale de l'activité de la maladie par le médecin) évalué sur une échelle de Likert à quatre correspondant à une maladie active très sévère, associé à un UCNT du nasopharynx stade I chez un patient altéré a été posé avec nécessité de débuter un traitement de la DM du fait de son activité extrême [I]. Le patient a bénéficié d'une corticothérapie à la dose de I $\mathrm{mg} / \mathrm{kg} / \mathrm{j}$ en injectable pendant trois jours, puis relais par voie orale pendant quatre mois et dégression lente de 2,5 $\mathrm{mg} / \mathrm{semaine}$. L'évolution fut marquée par une amélioration spectaculaire sous corticothérapie: PS à deux, ablation de la sonde nasogastrique d'alimentation et une nette régression des lésions cutanées avec un score CDASI à II ; une diminution du déficit moteur avec un MMT260 à 208 et baisse de moitié des valeurs des enzymes musculaires LDH : $160 \mathrm{UI} / \mathrm{L}$; CPK : $40 \mathrm{UI} / \mathrm{L}$. Ensuite, le traitement de son cancer a été instauré à savoir une radiothérapie exclusive à raison de $70 \mathrm{~Gy}$ en dose totale sur la tumeur en fractionnement de 2 Grays (Gy)/fraction (fr) en 35 séances de cinq séances/semaine. A la fin du traitement étiologique, nous retrouvions un patient autonome (PS à un I) avec une disparition des lésions cutanées (Figure 4) et récupération totale de la force musculaire.

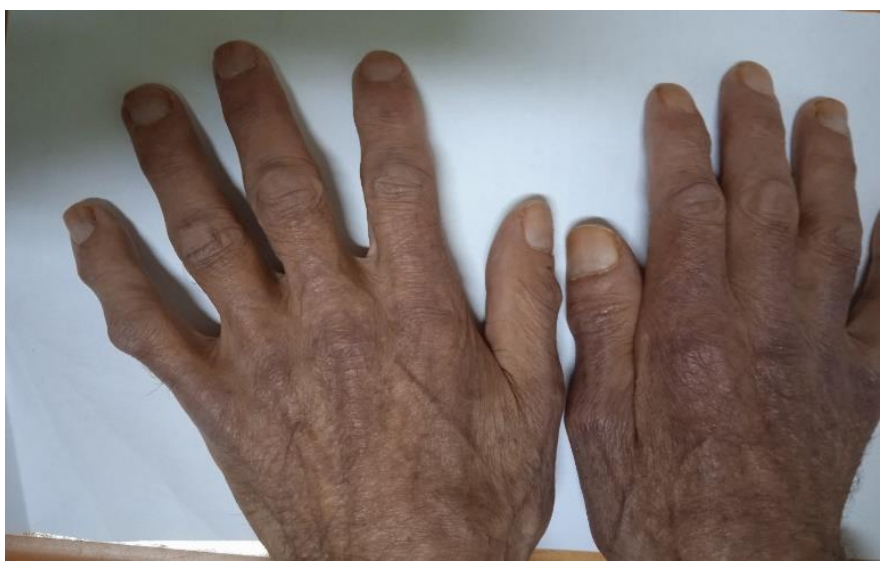

Figure 4 : Disparition des lésions cutanées.

\section{DISCUSSION}

Les carcinomes nasopharyngés (NPC) représentent moins de $1 \%$ de toutes les tumeurs malignes et affectent environ une personne sur 100.000 en Amérique du Nord et en Europe Occidentale, mais est plus fréquente en Asie et en Afrique du Nord. Ils affectent cinq à neuf personnes pour 100.000 habitants [5]. Le sous-type pathologique indifférencié est le plus fréquent avec une association fréquente avec des syndromes paranéoplasiques comme la fièvre, les réactions leucémoides d'ostéosthropathie [6]. L'association DM et cancer est fréquente allant de 18 à $32 \%$ [2]. Cependant son association avec le NPC est peu décrite. Le plus souvent, elle est associée au type indifférencié, un peu moins fréquemment au type peu différencié et jamais au cancer bien différencié [7]. Elle peut être plus grave que les conséquences de la tumeur primitive elle-même et peut précéder, suivre ou être concomitant au diagnostic du cancer. C'est le constat dans notre cas où la symptomatologie est dominée par la DM. La pathogénèse de la DM est encore mal connue et plusieurs mécanismes ont été suggérés. Deux théories ont été développées: la théorie hormonale et la théorie immunologique. Dans la première hypothèse, c'est la tumeur qui secrète des polypeptides hormonaux actifs sur le plan biologique mais inappropriés sur le plan homéostatique. 
Ces polypeptides seraient responsables des différents syndromes cliniques de types endocriniens [7]. Dans la théorie immuno-allergique, le syndrome paranéoplasique serait le résultat de réactions croisées des anticorps produits contre les antigènes tumoraux, avec les tissus normaux ayant une similitude de structures [7]. Le diagnostic de DM est basé sur cinq critères selon Bohan et Peter [8] : la faiblesse musculaire progressive et symétrique des ceintures et des muscles fléchisseurs du cou; des signes dermatologiques (éruptions cutanées à l'héliotrope avec œdèmes périorbitaires, papules de Grotton (dermatite squameuse sur les articulations des doigts), dermatite sur les coudes, les genoux et les pieds); une biopsie musculaire en faveur de myosites; une élévation des enzymes musculaires sériques témoignant de la nécrose musculaire (en particulier CPK, aldolase, LDH), ils sont augmentés chez 70 à $90 \%$ des patients, cependant un taux normal ne doit pas faire écarter le diagnostic [I] et le profil électromyographique en faveur d'une atteinte musculaire. La présence de trois ou quatre de ces critères, en plus de l'éruption cutanée permet de faire le diagnostic de DM et la présence de deux critères associés à l'éruption cutanée est très évocatrice de DM. Ainsi, devant la faiblesse musculaire progressive, l'élévation de la LDH associée à l'éruption cutanée typique, nous avons posé le diagnostic de DM paranéoplasique. La DM peut être idiopathique, en particulier chez les enfants. Mais elle est généralement liée à une tumeur maligne. Dans l'étude épidémiologique de Hill et al [2], 32\% des DM étaient associées à des cancers de l'ovaire, du poumon, du pancréas, du sein, du tractus gastro-intestinal ou à un lymphome non hodgkinien. Egalement, Chan et al [9] ont publié une série de cas de DM suivie à Singapour, dont $41 \%$ étaient des carcinomes du nasopharynx. Hu et al [10], dans une étude statistique en Chine trouvaient une association de la DM au cancer avec une incidence de $20.3 \%$ dont $78.5 \%$ concernait le NPC. Le traitement de la DM chez un patient atteint de cancer, implique le traitement de la DM et le traitement de la tumeur. II est identique chez les patients avec ou sans cancer associé. Le but de la thérapeutique dans la DM, est d'augmenter la force musculaire et d'améliorer les manifestations extra-musculaires. Le traitement en première intention est basé sur la corticothérapie à forte dose associée aux mesures hygiénodiététiques usuelles de la corticothérapie [II]. En effet, avant l'utilisation des corticoïdes, le pronostic des DM était médiocre avec une mortalité de 50 à $60 \%$ [12].

Les corticoïdes sont prescrits à la dose de $\mathrm{I} \mathrm{mg} / \mathrm{kg} / \mathrm{j}$ pendant quatre à huit semaines en moyenne, jusqu'à régression des signes cliniques et la nette diminution ou la normalisation des enzymes musculaires, puis une dégression progressive peut être entamée jusqu'à l'obtention de la dose minimale efficace qui sera maintenue pendant six à neuf mois sans rechute [13]. Pour les formes sévères de DM, l'utilisation de bolus intraveineux de méthyl-prednisolone à la dose de I mmg/kg/j pendant trois jours, puis relais par voie orale est recommandée [12]. Ce fut le cas pour notre patient admis dans un état altéré qui a reçu un bolus en injectable, puis relais par voie orale. Cependant en cas de DM réfractaire ou corticodépendance, d'autres options thérapeutiques sont utilisées telles que le méthotrexate, l'azthioprine, les immunoglobulines intraveineuses et rituximab [14]. En plus de la corticothérapie, il faut associer le traitement du NPC. S'agissant du stade I, le traitement est la radiothérapie exclusive de 70 Gy en fractionnement de $2 \mathrm{~Gy} / \mathrm{fr}$ en 35 séances, cinq séances/semaine comme dans notre cas. Le pronostic du NPC avec DM est le même que celui d'un NPC en général. En effet, Hu et al, dans une étude cas-témoins, montraient un taux de survie de cinq et dix ans et un taux de métastase à distance, respectivement de 50,$4 ; 34,5$ et $40,5 \%$ pour les patients NPC atteints de DM et de 57,$8 ; 55,2$ et $56,5 \%$ pour les témoins non-atteints de DM. Les résultats montraient que la radiothérapie à la prednisone est un traitement non-seulement assez efficace, mais aussi n'entrainerait pas non plus une augmentation significative du taux de métastases à distance [10]. En plus, de nombreux auteurs ont rapporté qu'une rémission complète après une radiothérapie sur la tumeur entrainait la disparition ou l'amélioration des symptômes et des signes physiques du DM. Ainsi, la rechute du DM était corrélée à une récidive locorégionale ou à la détection de métastases, constituant alors un élément de surveillance après traitement de NPC.

\section{CONCLUSION}

Les NPC avec DM paranéoplasique sont une entité rare. Le diagnostic de DM est basé sur cinq critères cliniques et paracliniques. II est parfois révélateur de certains NPC, constituant alors un élément aussi bien de diagnostic précoce que de surveillance. Ainsi, devant une DM survenant chez des malades originaires des zones endémiques, le NPC doit être recherché en priorité. En plus, l'association du DM avec le NPC ne semble pas influencer le pronostic du cancer, d'où l'intérêt d'une prise en charge rapide de la DM pour améliorer la qualité de vie du patient et lui permettre de supporter les traitements spécifiques du cancer.

\section{CONFLITS D'INTERET}

Les auteurs n'ont déclaré aucun conflit d'intérêts.

\section{REFERENCES}

I. Brigitte Bader-Meunier et Olivier Benveniste. Protocole National de Diagnostic et de Soins (PNDS) Dermatomyosite de l'enfant et de l'adulte. Juillet 2016. 10.

www.has-sante.fr.

2. Hill, C. L., Y. Zhang, B. Sigurgeirsson, E. Pukkala, L. Mellemkjaer, A. Airio, S. R. Evans, et D. T. Felson. « Frequency of Specific Cancer Types in Dermatomyositis and Polymyositis : A PopulationBased Study ». Lancet (London, England) 357, no 9250 (I3 janvier 200I) : 96 I00. https://doi.org/10.1016/S0140-6736(00)03540-6.

3. Ziani, Fatima Zahra, Sami Aziz Brahmi, Rajae Najib, Rajae Kanab, Samia Arifi, Fatima Zahra Mernissi, et Nawfal Mellas. « [Paraneoplastic dermatomyositis revealing an undifferentiated nasopharyngeal carcinoma : about a case] ». The Pan African Medical Journal 24 (2016) : 29.

https://doi.org// 0.1 I604/pamj.2016.24.29.4822.

4. Chakroun, A., J. Guigay, A. Lusinchi, P. Marandas, F. Janot, et D.M. Hartl. " Paraneoplastic Dermatomyositis Accompanying Nasopharyngeal Carcinoma : Diagnosis, Treatment and Prognosis ». European Annals of Otorhinolaryngology, Head and Neck Diseases 128, no 3 (juin 20II) : I 2731. https://doi.org/10.1016/j.anorl.2010.10.007.

5. Vasef, Mohammad A., Alfio Ferlito, et Lawrence M. Weiss. « Nasopharyngeal Carcinoma, with Emphasis 
on Its Relationship to Epstein-Barr Virus ». Annals of Otology, Rhinology \& Laryngology 106, no 4 (avril 1997) : 34856.

https://doi.org//0.1 I77/0003489497/06004/6.

6. Toro, C., A. Rinaldo, C.E. Silver, M. Politi, et A. Ferlito. « Paraneoplastic Syndromes in Patients with Nasopharyngeal Cancer ». Auris Nasus Larynx 36, no 5 (octobre 2009) : 51320.

https://doi.org/l0.1016/j.anl.2008.10.006.

7. Maalej, M., A. Ladgham, A. Ennouri, A. Ben Attia, M. Cammoun, et R. Ellouze. " [The paraneoplastic syndrome in nasopharynx cancer. 32 cases] 11 . Presse Medicale (Paris, France : 1983) 14, no 8 (23 février 1985) : 47। 74.

8. Bohan, A., et J. B. Peter. « Polymyositis and Dermatomyositis (First of Two Parts) ॥. The New England Journal of Medicine 292, no 7 ( 3 février 1975) : 34447.

https://doi.org/10.1056/NEJMI 97502 I 32920706.

9. Chan, H. L. " Dermatomyositis and Cancer in Singapore ». International Journal of Dermatology 24, no 7 (septembre 1985) : 44750. https://doi.org/ | 0.1 | | I/j.| 365-4362.1985.tb058|6.x.

10. Wj, Hu, Chen DI, et Min Hq. "Study of 45 cases of nasopharyngeal carcinoma with dermatomyositis ». American journal of clinical oncology. Am J Clin Oncol, février 1996.

https://doi.org/10.1097/0000042 I-199602000-00008.

I I. Frikha, Faten, Mouna Snoussi, Raida Ben Salah, Noura Saidi, Neila Kaddour, et Zouhir Bahloul. « [Dermatomyositis in the elderly : a study of 4 cases in southern Tunisia] ». The Pan African Medical Journal 13 (20I2) : 26.

12. Marie, Isabelle, et Luc Mouthon. " Therapy of Polymyositis and Dermatomyositis ». Autoimmunity Reviews II, no I (I novembre 20 I I) : 6 I3. https://doi.org/10.1016/j.autrev.2011.06.007.

13. Chérin, P. « [Current therapy for polymyositis and dermatomyositis] ॥. La Revue De Medecine Interne 29 Spec No 2 (juin 2008) : 9 I4.

14. Pautas, E., P. Chérin, J. C. Piette, S. Pelletier, B. Wechsler, J. Cabane, et S. Herson. "Features of Polymyositis and Dermatomyositis in the Elderly: A Case-Control Study ». Clinical and Experimental Rheumatology 18, no 2 (avril 2000) : 24I 44. 


\section{DECLARATIONS}

- Approbation éthique et consentement à participer : sans objet.

- Consentement à la publication : sans objet.

- Disponibilité des données et du matériel : sans objet.

- Intérêts concurrents : les auteurs ne déclarent aucun conflit d'intérêts.

- $\quad$ Financement : sans objet.

- Contributions des auteurs : tous les auteurs ont contribué à la rédaction et l'élaboration de cet article. Ils ont également tous lu et approuvé la version finale du manuscript.

- $\quad$ Remerciements : sans objet. 
An official journal of the / Un journal officiel de la "Société Sénégalaise de Cancérologie" (SOSECAN)

Journal homepage: www.africanjournalofoncology.com

\title{
Giant jejunal gasto-intestinal stromal tumor: A rare cause of abdominal mass in an elderly female
}

Tumeur stromale gastro-intestinale à localisation jéjunale : Une rare cause de masse abdominale chez la femme âgée

\author{
AC. Diallo', A. Ndong', I. Niang', MB. Ba ${ }^{3}$, JA. Thiam³, PS. Dieng' ${ }^{3}$ S. Ka ${ }^{3}$ I. Konate', A. Dem³
}

' UFR 2S, Université Gaston Berger de Saint-Louis, Sénégal.

${ }^{2}$ Service de Radiologie, Centre Hospitalier de Fann, Sénégal.

${ }^{3}$ Institut Joliot Curie de Dakar, Sénégal.

OBJECTIVE: We report the case of a patient presenting an abdominal mass whose final diagnosis is a gastrointestinal stromal tumor (GIST). CLINICAL OBSERVATION: It was a 61 -year-old patient with no pathological history received for a progressive increase in the volume of the abdomen evolving for one year and painless. On examination, the patient was in good general condition, with normal patterns. There was an abdomino-pelvic mass of about $20 \mathrm{~cm}$ long axis, mobile. The rest of the exam was unremarkable. The biological assessment was normal. Abdominopelvic computed tomography revealed a tissue mass with necrosis. During the surgical exploration, a mass developed on the mesenteric border $45 \mathrm{~cm}$ from the Treitz angle was noted. It is not associated with ascites or peritoneal carcinoma. Bowel resection removing the mass was performed followed by end-to-end anastomosis. Pathological examination of the surgical specimen diagnosed GIST. The postoperative course at three months was excellent both clinically and radiologically. CONCLUSION: The case that we report underlines the possible jejunal localization of GIST and the clinical presentation may be usual. It also shows the difficulty of obtaining a preoperative diagnosis and the central role of surgery in management.

KEYWORDS: Gastrointestinal stromal tumor; Jejunal GIST; Surgery; Bowel resection; Imatinib.

OBJECTIF : Nous rapportons le cas d'une patiente présentant une masse abdominale dont le diagnostic final est une tumeur stromale gastro-intestinale (GIST). OBSERVATION : II s'agissait d'une patiente âgée de $6 \mathrm{I}$ ans sans antécédents pathologiques, reçue pour une augmentation progressive de volume de l'abdomen évoluant depuis un an, indolore. A l'examen, la patiente avait un bon état général, des constantes normales. Nous notions une masse abdomino-pelvienne d'environ $20 \mathrm{~cm}$ de grand axe, mobile. Le reste de l'examen était sans particularité. Le bilan biologique était normal. La tomodensitométrie abdominopelvienne mettait en évidence une masse tissulaire avec des remaniements nécrotiques. Une indication opératoire a été posée. A l'exploration, nous notions une masse développée sur le bord mésentérique à $45 \mathrm{~cm}$ de l'angle de Treitz. Elle n'est pas associée à de l'ascite ou à une carcinose péritonéale. II n'y avait pas de lésion hépatique également. La résection intestinale emportant la masse a été réalisée suivie d'une anastomose termino-terminale. Les suites opératoires étaient simples. L'examen anatomo-pathologique de la pièce opératoire a posé le diagnostic d'une GIST. L'évolution post-opératoire à trois mois était excellente tant sur le plan clinique que radiologique. CONCLUSION : Le cas que nous rapportons souligne la possibilité de retrouver une GIST à localisation jéjunale malgré une présentation clinique peu usuelle. Elle montre également la difficulté d'obtenir un diagnostic préopératoire et le rôle central de la chirurgie dans la prise en charge.

MOTS-CLES : Tumeur stromale gastro-intestinale ; GIST jéjunale ; Chirurgie ; Résection intestinale ; Imatinib.

\section{INTRODUCTION}

Les tumeurs stromales gastro-intestinales (GIST) sont des tumeurs mésenchymateuses rares [I]. La localisation gastrique est la plus fréquente (60\%) [2]. L'atteinte jéjunale est beaucoup plus rare ( 3 à $5 \%$ ). La symptomatologie varie selon le siège et l'évolution. Elle est souvent peu spécifique. Dans environ la moitié des cas, les patients présentent une masse abdominale et dans moins de $1 \%$ des cas, une hémorragie digestive [3]. Nous rapportons le cas d'une patiente avec une GIST à localisation jéjunale avec une symptomatologie peu fréquente.

\section{OBSERVATION CLINIQUE}

II s'agissait d'une patiente âgée de $6 \mathrm{I}$ ans sans antécédents pathologiques, reçue pour une augmentation progressive de volume de l'abdomen évoluant depuis un ans, indolore. Elle présentait plusieurs épisodes de mélaena. A l'examen, la patiente avait un bon état général, des constantes normales. Nous notions une masse abdomino-pelvienne d'environ $20 \mathrm{~cm}$ de grand axe, mobile. Le reste de l'examen était sans particularité. Le bilan biologique était normal. La tomodensitométrie abdominopelvienne (TDM) mettait en évidence une masse volumineuse masse tissulaire de $18 \times 12 \times$ $18 \mathrm{~cm}$, avec des remaniements nécrotiques sans possibilité d'être formelle sur son origine. II n'y avait pas d'autre lésion abdominopelvienne visualisée (Figure I). Une indication opératoire a été posée. A l'exploration, nous notions une masse développée sur le bord mésentérique à $45 \mathrm{~cm}$ de l'angle de Treitz (Figure 2). Elle n'est pas associée à de l'ascite ou à 
une carcinose péritonéale. II n’y avait pas de lésion hépatique également.

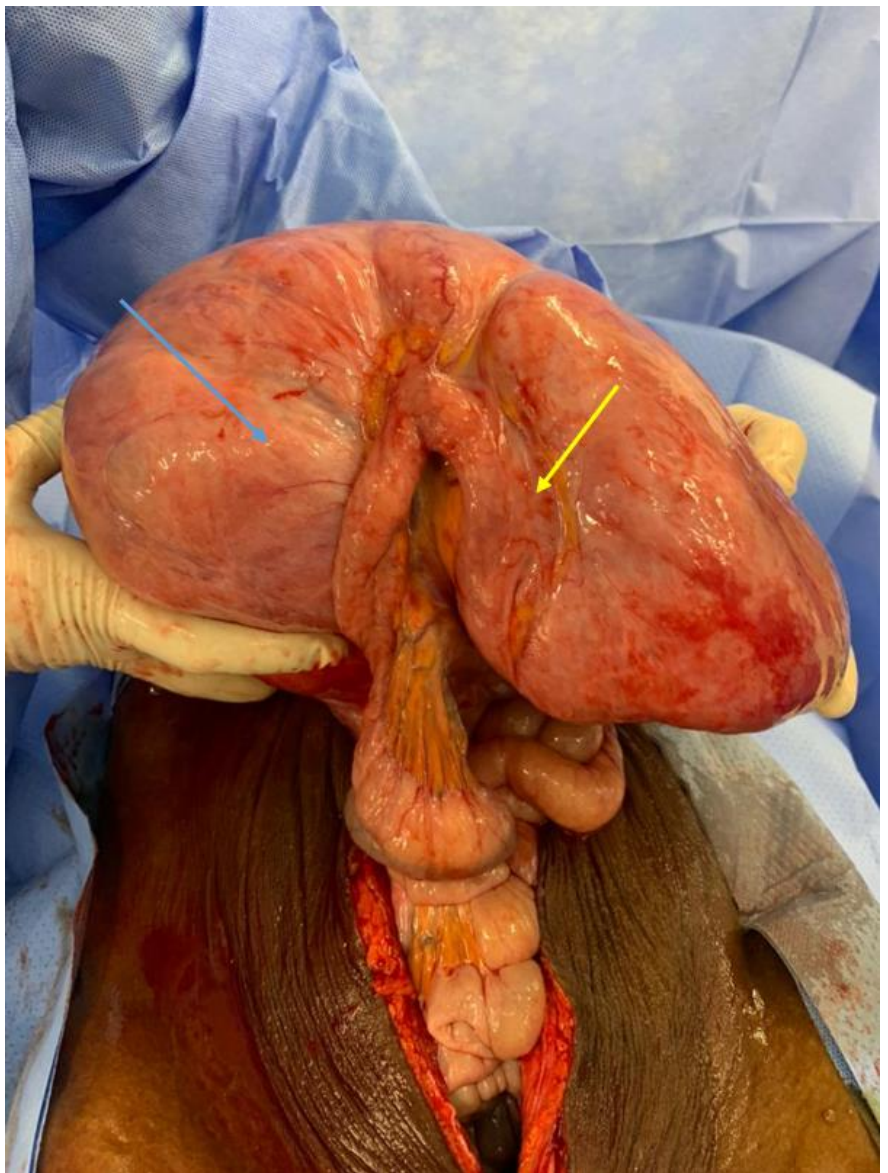

Figure I : Aspect peropératoire de la masse (flèche bleue) développée aux dépens de la première anse jéjunale sur son bord mésentérique (flèche jaune).

La résection intestinale emportant la masse a été réalisée suivie d'une anastomose termino-terminale. Les suites opératoires étaient simples. L'examen anatomo-pathologique de la pièce opératoire avait objectivé des cellules fusiformes grêliques infiltrant la sous séreuse. L'étude immunohistochimique montrait un marquage net diffus de la population tumorale visà-vis du Ckit et du DOGI, le marquage de l'actine muscle lisse et de la PSI00 étaient négatif. L'aspect morphologique et immunohistochimique correspondait donc à une GIST à localisation jéjunale et à indice mitotique faible (inférieur à cinq). L'évolution post-opératoire à trois mois était excellente tant sur le plan clinique que radiologique.

\section{DISCUSSION}

Les GIST sont des tumeurs rares et leur diagnostic est rarement aisé. Elles sont souvent asymptomatiques ou donnent des symptômes peu spécifiques [4, 5]. Les GIST surviennent surtout chez les adultes avec une médiane d'âge de 65 ans [4]. II n'existe pas de prédominance particulière en fonction du sexe dans la plupart des séries publiées [5]. Les circonstances de découverte sont multiples et non spécifiques. La localisation gastrique est plus fréquemment retrouvée comparée à la localisation jéjunale [6, 7]. Le plus souvent, les GIST à localisation jéjunale sont asymptomatiques. Elles se présentent le plus souvent sous la forme d'une masse avec une taille moyenne plus importante. Le diagnostic peut être posé rarement à la suite d'une hémorragie digestive [4, 6]. En effet, les GIST sont responsables dans 5 à $10 \%$ des causes de saignements digestifs occultes [4]. Dans notre cas, la patiente avait des épisodes de mélaena.

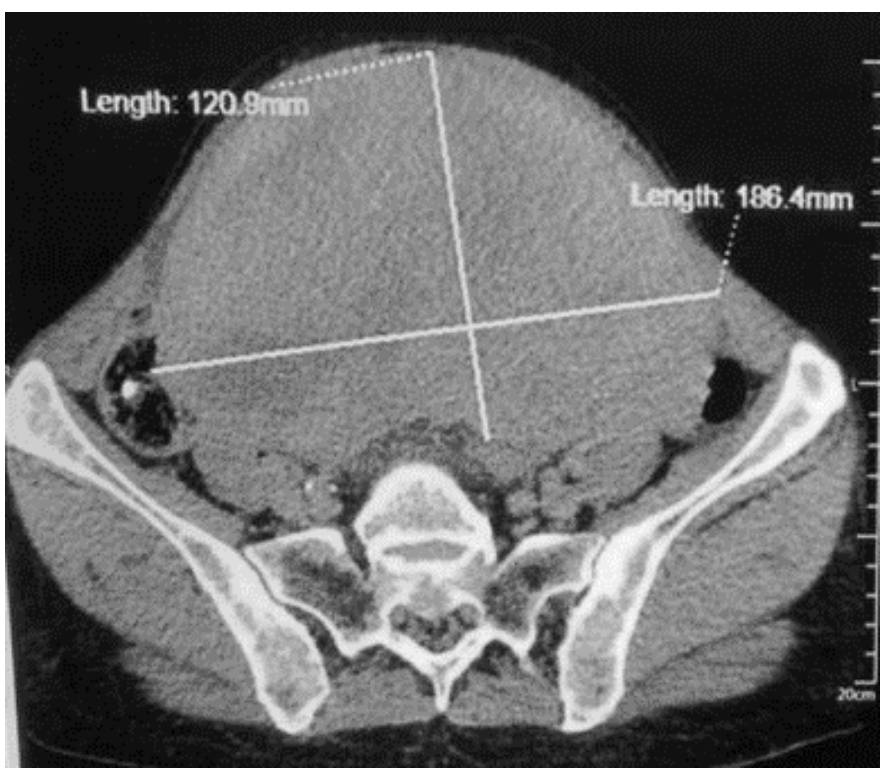

Figure 2A.

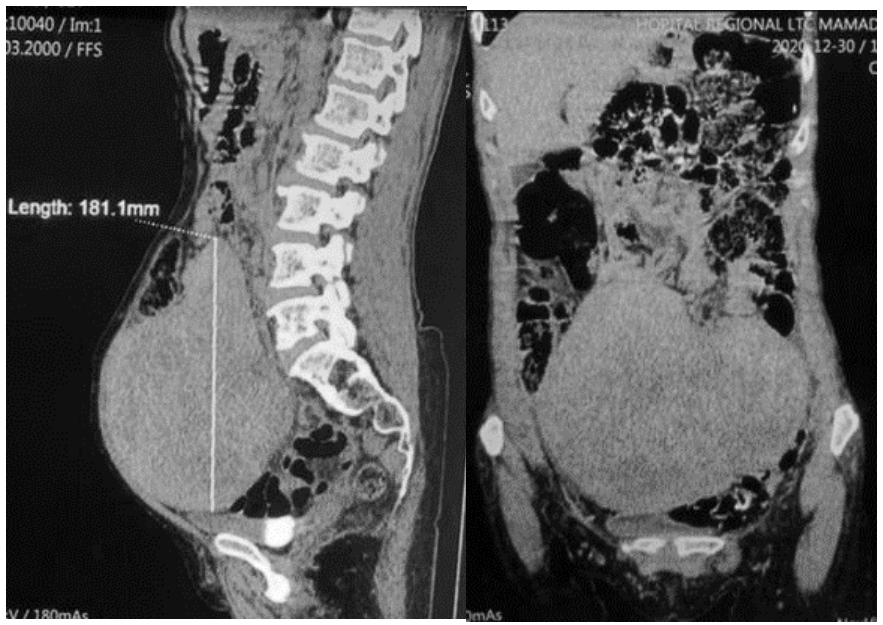

Figure 2B.

Figure 2 : TDM en coupe transversale avec reconstruction coronale (2A) et sagittale (2B) montrant la volumineuse masse tissulaire abdominopelvienne.

Le plus souvent, la tumeur se développe de façon extraluminale rendant l'endoscopie digestive et la biopsie peu contributive $[4,8]$. La TDM occupe une place centrale dans le cadre du diagnostic des GIST à localisation grêlique [9]. Elle permet de caractériser la tumeur, sa taille et son extension locorégionale.

Le diagnostic histologique est rarement obtenu en préopératoire. En effet, la biopsie entraine un haut risque de dissémination ou d'hémorragie. Il est surtout nécessaire en cas de tumeur métastatique ou non-résécable. L'aspect histologique des GIST est variable. Les cellules peuvent être fusiformes dans $70 \%$ des cas, épithélioïdes dans $20 \%$ des cas ou une combinaison de ces deux aspects $[10,1 \mathrm{I}]$. Le diagnostic anatomopathologique repose sur l'histopathologie et l'immunohistochimie. La recherche d'une expression des antigènes CDI I7, positive dans $95 \%$ des cas, permet d'affirmer le diagnostic. Cependant, il faut noter l'existence de faux positifs [12]. 
La chirurgie malgré l'apport de l'imatinib est le principal traitement curatif des GIST. II est recommandé de réaliser une résection complète avec des marges saines [7]. Les marges de résection doivent être au moins deux $\mathrm{cm}$ [13]. Du fait de l'absence d'atteinte ganglionnaire dans la grande majorité des cas, le curage ganglionnaire n'est pas systématique [ $\mathrm{I} \mathrm{I}$ ].

Les facteurs pronostiques sont la taille tumorale supérieure à $10 \mathrm{~cm}$, le siège de la tumeur, l'atteinte de la séreuse, un index mitotique (supérieur à 5 mitoses par 50 champs au fort grossissement), l'existence d'atypies nucléaires, l'état des marges de résection et l'existence d'une mutation Ckit [14]. L'exérèse chirurgicale complète assure $95 \%$ de survie après cinq ans.

\section{CONCLUSION}

Le cas que nous rapportons souligne la possible localisation jéjunale des GIST et la présentation clinique peu usuelle. II montre également la difficulté d'obtenir un diagnostic préopératoire et le rôle central de la chirurgie dans la prise en charge.

\section{CONFLITS D'INTERET}

Les auteurs n'ont déclaré aucun conflit d'intérêts.

\section{REFERENCES}

I. Global epidemiology of gastrointestinal stromal tumours (GIST): A systematic review of populationbased cohort studies. Cancer Epidemiol. 2016 Feb I;40:39-46.

2. Keung EZ, Raut CP. Management of Gastrointestinal Stromal Tumors. Surg Clin North Am. 2017 Apr I;97(2):437-52.

3. Roy SD, Khan D, De KK, De U. Spontaneous perforation of jejunal gastrintestinal stromal tumour (gist). Case report and review of literature. World J Emerg Surg. 2012 Nov 29;7(I):37.

4. Melo C, Canhoto C, Manata F, Bernardes A. Surgical treatment of giant gist with acute gastrointestinal bleeding: Case report. Int J Surg Case Rep. 2018 Jan I;53:354-7.

5. Somé OR, Tankoano IA, Koura M, Konségré $V$, Konkobo D, Koulidiaty J. Hepatic Metastatic GIST: Diagnostic and Therapeutic Difficulties in Souro Sanou Teaching Hospital in Bobo Dioulasso, Burkina Faso. Open J Gastroenterol. 2018 Dec 27;08(I 2):455.

6. Fall $F$, Ndiaye $B, N$ diaye $A R$, Diagne Guèye NM, Gning $\mathrm{SB}$, Niang $A$, et al. Les tumeurs stromales digestives " GIST » : étude rétrospective de dix cas au Sénégal. J Afr Hépato-Gastroentérologie. 201 I Jul 30;5(3):210.

7. Ka S, T M, Diallo A, T J, D A. Voluminous Gastric Stromal Tumors: Place of Surgery about 5 Cases at the Dakar Cancer Institute. J Gastrointest Cancer Stromal Tumors. 2017 Jan 1;02.

8. Akahoshi K, Oya M, Koga T, Shiratsuchi Y. Current clinical management of gastrointestinal stromal tumor. World J Gastroenterol. 2018 Jul 14;24(26):2806-17.

9. Burkill GJC, Badran M, Al-Muderis O, Meirion Thomas J, Judson IR, Fisher C, et al. Malignant Gastrointestinal Stromal Tumor: Distribution, Imaging Features, and Pattern of Metastatic Spread. Radiology. 2003 Feb;226(2):527-32.
10. Demetri GD, Benjamin RS, Blanke CD, Blay J-Y, Casali $P$, Choi $H$, et al. NCCN Task Force Report: Management of Patients with Gastrointestinal Stromal Tumor (GIST)-Update of the NCCN Clinical Practice Guidelines. J Natl Compr Canc Netw. 2007 May I;5(S2):S-S-29.

II. Zwan SM van der, DeMatteo RP. Gastrointestinal stromal tumor: 5 years later. Cancer. 2005; | 04(9): | 78|-8.

12. Dow N, Giblen G, Sobin LH, Miettinen M. Gastrointestinal stromal tumors: Differential diagnosis. Semin Diagn Pathol. 2006 May I;23(2): I I I9.

13. Barbu LA, Margaritescu N-D, Ghilusi M-C, Belivaca D, Georgescu EF, Ghelase M, et al. Severe upper gastrointestinal bleeding from gastrointestinal stromal tumor of the stomach. Rom J Morphol Embryol. 2016;57(4): I397-40।.

14. Caterino S, Lorenzon L, Petrucciani N, lannicelli E, Pilozzi E, Romiti A, et al. Gastrointestinal stromal tumors: correlation between symptoms at presentation, tumor location and prognostic factors in 47 consecutive patients. World J Surg Oncol. 201 I Feb $1 ; 9: 13$. 
This page is intentionally left blank.

Cette page est laissée blanche intentionnellement. 
SOSECAN TOUS UNIS CONTRE LES CANCERS 


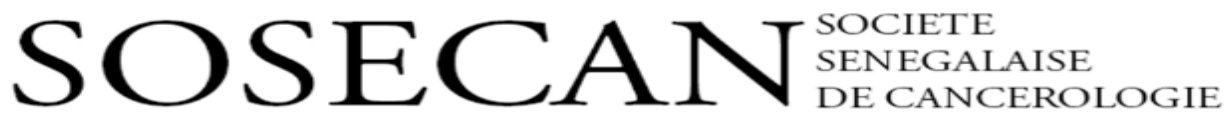

TOUS UNIS CON TRE LES C A N C ERS

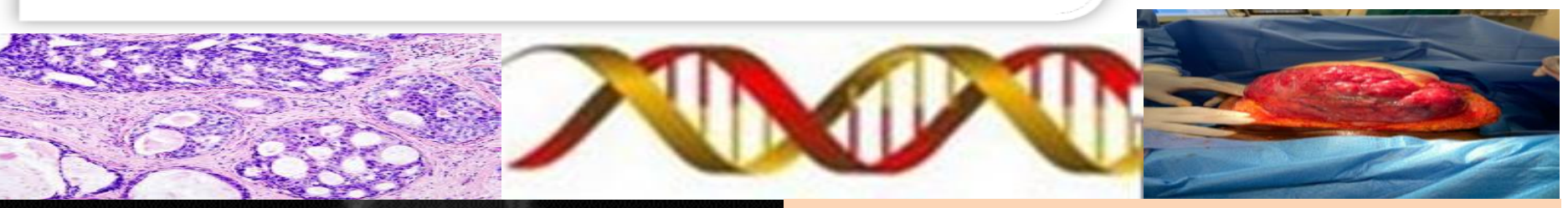

\section{Programme}

Cours international sur les concers gynécologiques

\section{Conférences}

\section{Communications libres}

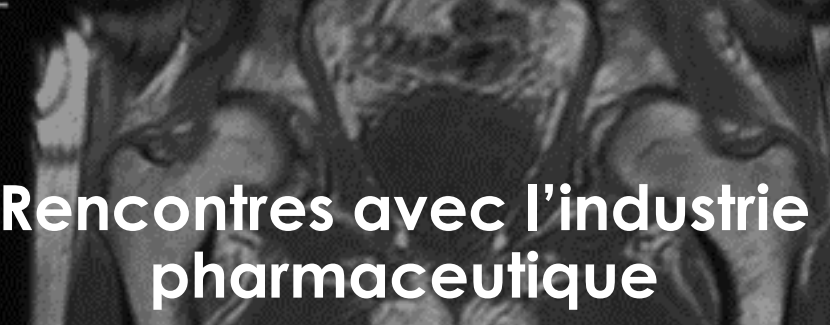

Société Sénégalaise de Cancérologie (SOSECAN)

米

\section{$3^{\text {ème }}$ congrès annuel}

14 et 15 décembre 2021

*

Au Musée des Civilisations Africaines En présentiel et En ligne

*

Date limite de soumission des résumés 15 novembre 2021

\section{Inscriptions :}

Spécialistes : 50.000 fcfa; Ełudiants et infirmiers : 25.000 fcfa

Email : sosecan.info@gmail.com

Tél : +221 775587357 / +221 772978318 